\title{
U.S. Geological Survey-Energy and Wildlife Research Annual Report for 2016
}
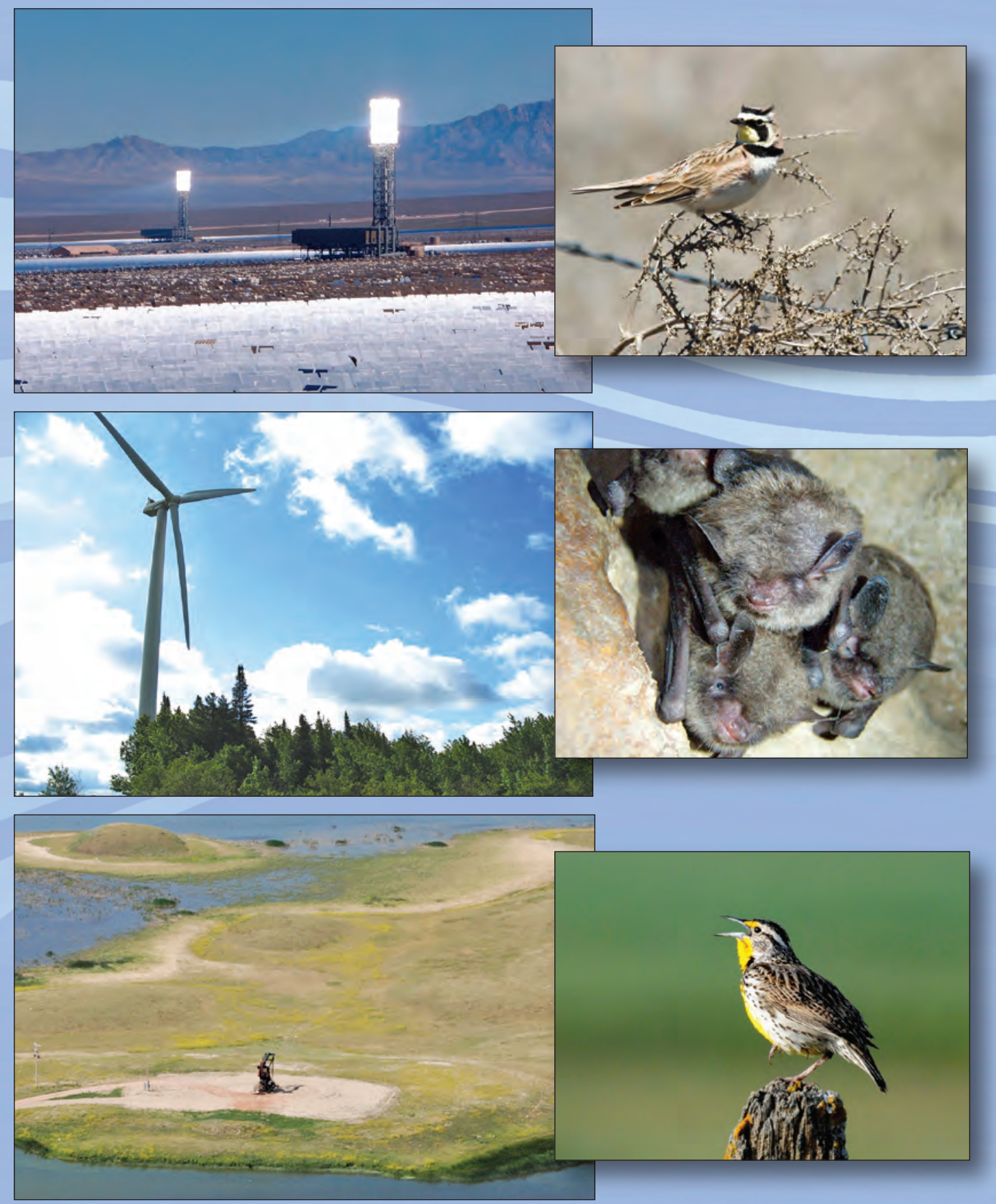

Open-File Report 2016-1147

U.S. Department of the Interior

U.S. Geological Survey 


\title{
U.S. Department of the Interior SALLY JEWELL, Secretary
}

\author{
U.S. Geological Survey \\ Suzette M. Kimball, Director
}

U.S. Geological Survey, Reston, Virginia: 2016

For more information on the USGS —-the Federal source for science about the Earth, its natural and living resources, natural hazards, and the environment-visit http://www.usgs.gov or call 1-888-ASK-USGS.

For an overview of USGS information products, including maps, imagery, and publications,

visit http://store.usgs.gov/.

Any use of trade, firm, or product names is for descriptive purposes only and does not imply endorsement by the U.S. Government.

Although this information product, for the most part, is in the public domain, it also may contain copyrighted materials as noted in the text. Permission to reproduce copyrighted items must be secured from the copyright owner.

Suggested citation:

Khalil, Mona, ed., 2016, U.S. Geological Survey—Energy and Wildlife research annual report for 2016: U.S. Geological Survey Open-File Report 2016-1147, 59 p., http://dx.doi.org/10.3133/ofr20161147.

ISSN 0196-1497 (print) ISSN 2331-1258 (online) ISBN 978-1-4113-4084-8

Cover. Resident and migratory species at risk due to expanding development of energy generation facilities.

Top, Ivanpah solar power facility (USGS) and horned lark (Todd Katzner, USGS)

Middle, wind turbine (Paul Cryan, USGS) and Indiana bats (Ann Forschauer, USFWS)

Bottom, oil well in Prairie Pothole region, N.D. (Rachel Harrington, USGS), and western meadowlark

(Don Metzner, Cornell Lab of Ornithology, used with permission) 


\section{Contents}

Research to Understand Risks, Measure Impacts, and Inform Solutions .........................................

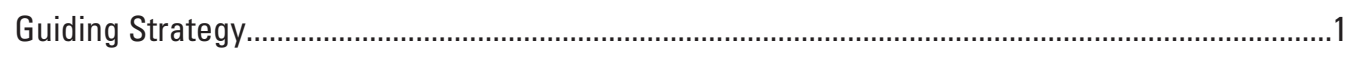

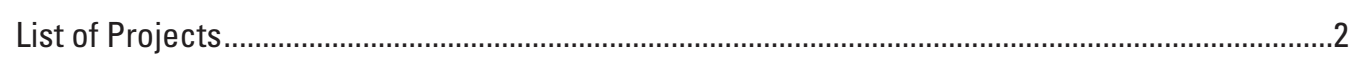

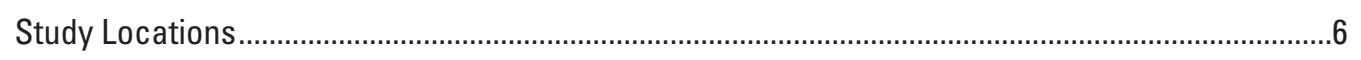

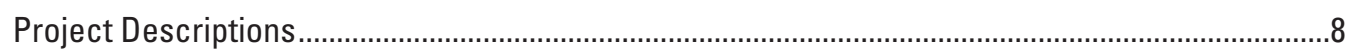

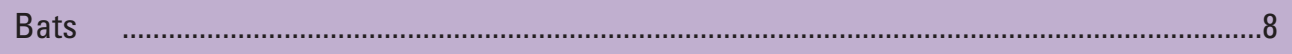

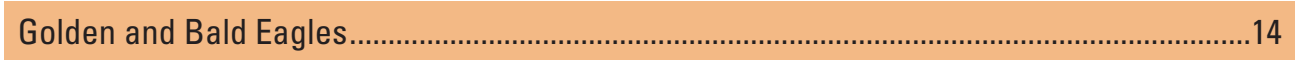

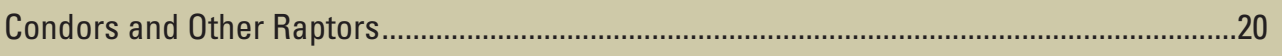

Great Lakes, Coastal, and Marine Birds ........................................................................23

Grassland Birds and Waterbirds ....................................................................................30

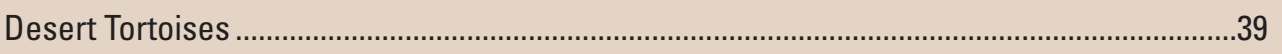

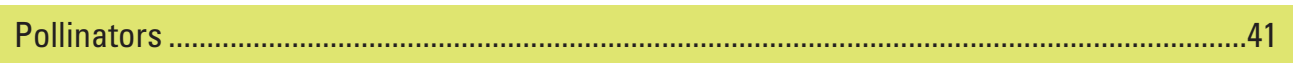

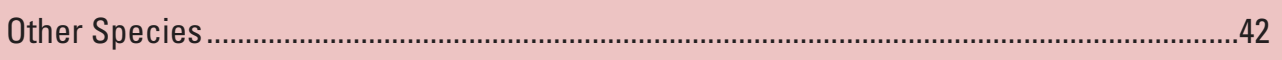

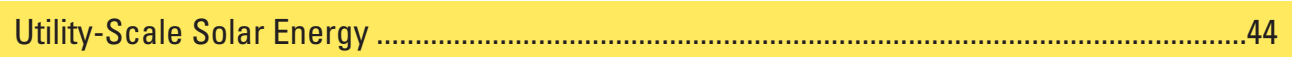

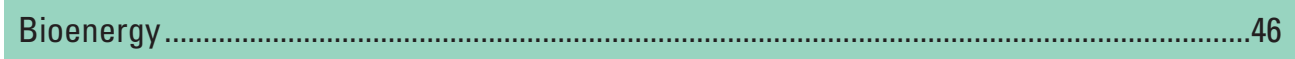

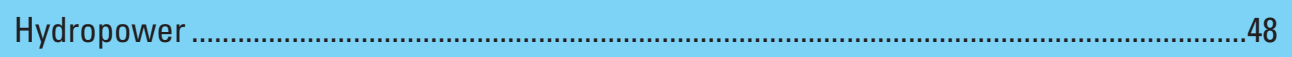

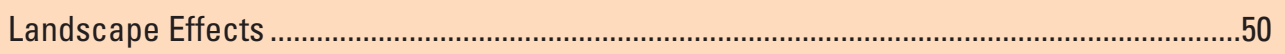

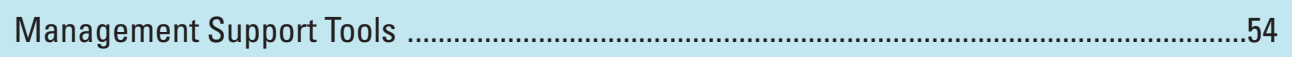

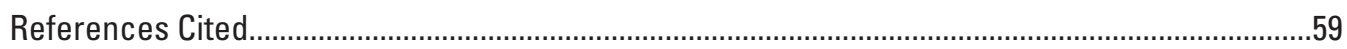

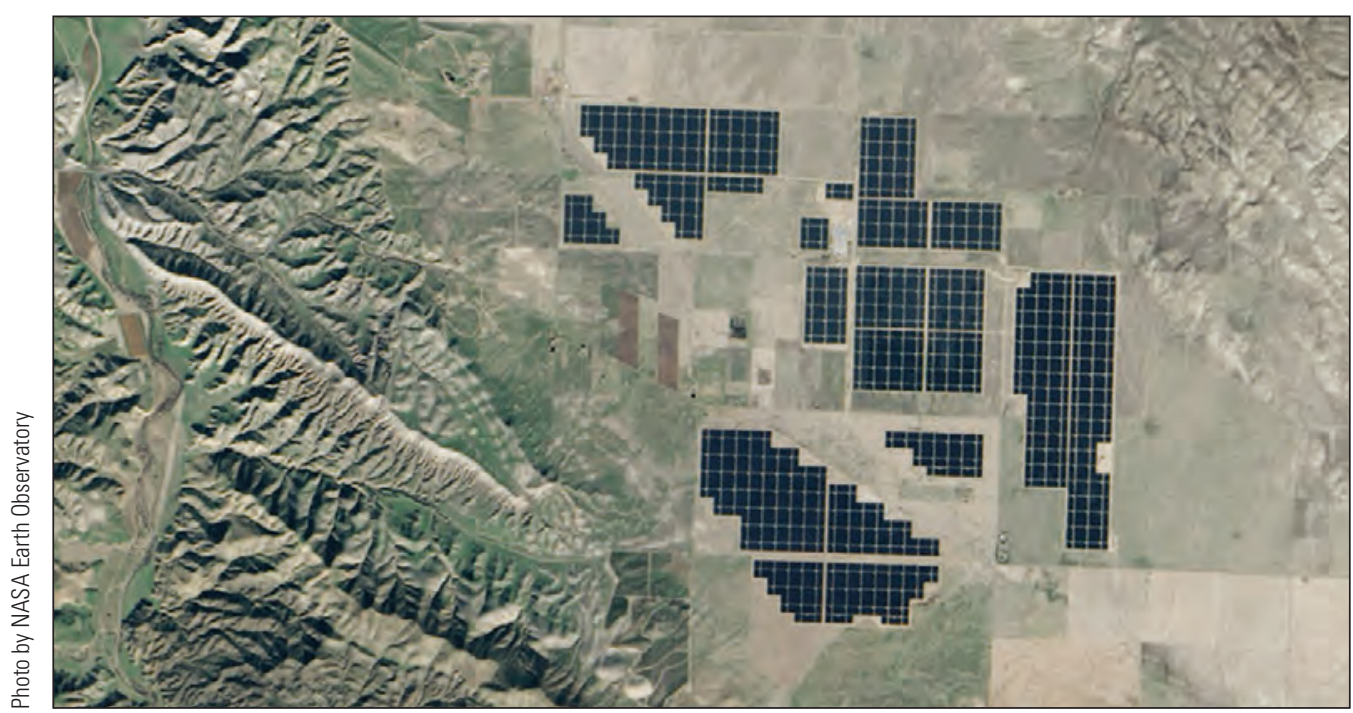

Utility-scale solar farm on the Carrizo Plain in southern California. 


\section{Abbreviations}

$\begin{array}{ll}\text { ABR } & \text { auditory brainstem response } \\ \text { BACI } & \text { Before-After, Control-Impact } \\ \text { BLM } & \text { Bureau of Land Management } \\ \text { BOEM } & \text { Bureau of Ocean Energy Management } \\ \text { CFWRU } & \text { Cooperative Fish and Wildlife Research Unit } \\ \text { DNA } & \text { deoxyribonucleic acid } \\ \text { DRECP } & \text { Desert Renewable Energy Conservation Plan } \\ \text { FAA } & \text { Federal Aviation Administration } \\ \text { GIS } & \text { geographic information system } \\ \text { GPS-GSM } & \text { global positioning system-global system for mobile communications } \\ \text { NABat } & \text { North American Bat Monitoring Program } \\ \text { NOAA } & \text { National Oceanic and Atmospheric Administration } \\ \text { NPS } & \text { National Park Service } \\ \text { NWFSC } & \text { Northwest Fisheries Science Center } \\ \text { OCS } & \text { Outer Continental Shelf } \\ \text { USDA } & \text { U.S. Department of Agriculture } \\ \text { USFWS } & \text { U.S. Fish and Wildlife Service } \\ \text { USGS } & \text { U.S. Geological Survey } \\ \text { UV } & \text { ultraviolet } \\ \text { VCFWRU } & \text { Virginia Cooperative Fish and Wildlife Research Unit } \\ \text { WLCI } & \text { Wyoming Landscape Conservation Initiative } \\ \text { WNS } & \text { white-nose syndrome }\end{array}$

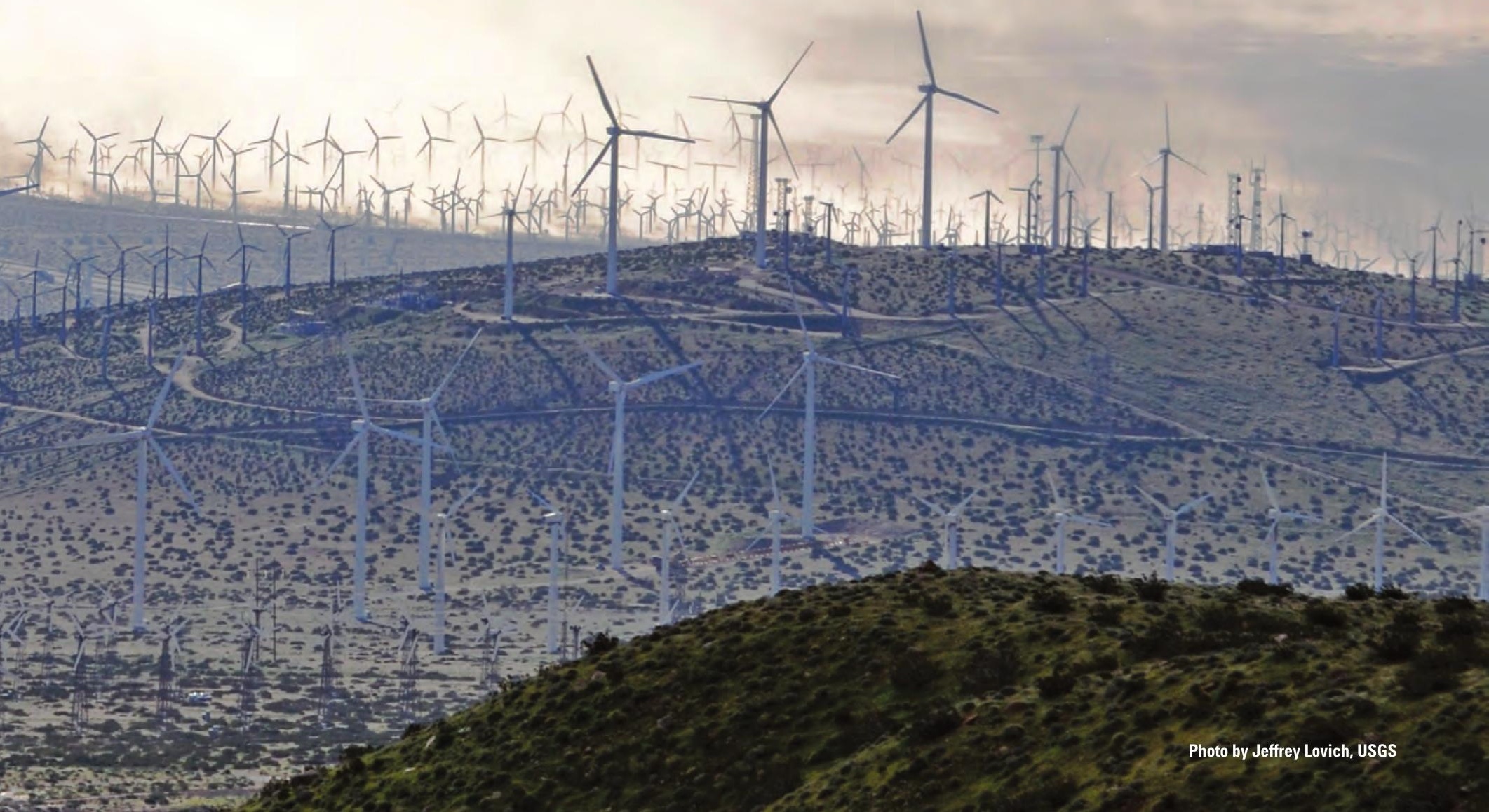




\title{
U.S. Geological Survey-Energy and Wildlife Research Annual Report for 2016
}

\author{
Mona Khalil, editor
}

\section{Research to Understand Risks, Measure Impacts, and Inform Solutions}

Recent growth and development of renewable energy and unconventional oil and gas extraction are rapidly diversifying the energy supply of the United States. Yet, as our Nation works to advance energy security and conserve wildlife, some conflicts have surfaced. To address these challenges, the U.S. Geological Survey (USGS) is conducting innovative research and developing workable solutions to reduce the impacts of energy production on wildlife. USGS scientists collaborate on many studies with scientists from other Federal, State, and local government agencies; Tribal nations; academic research institutions; and nongovernmental and private organizations.

The mix of fuels used for electricity generation is evolving. Solar, natural gas, and wind energy made up most electricity generation additions in 2015 and 2016. The United States now leads the world in natural gas production, with new record highs for each year from 2011 through 2015. More than 48,000 wind turbines now contribute to power grids in most States, providing about 5 percent of U.S. end-use electricity demand in an average year. The number of utility-scale solar-energy projects is growing rapidly with solar energy projected to contribute to the largest electricity generation addition in 2016 (U.S. Energy Information Administration, 2016).

A substantial number of large energy projects have been constructed on undeveloped public lands, and more are anticipated at an increasing rate, creating new stress to wildlife. Direct impacts include collisions with wind turbines and structures at solar facilities and loss of habitat which may negatively affect sensitive species. Recent estimates suggest 250,000 to 500,000 birds die each year at wind turbine facilities (Johnson and others, 2016). Bat fatality rates at wind turbine facilities are less certain, but may average several hundred thousand per year throughout North America (Hein and Schirmacher, 2016). Because new projects may be located in or near sensitive wildlife habitats, ecological science plays a key role in helping to guide project siting and operational decisions.

\section{Guiding Strategy}

USGS research provides scientific information and science-based options that government agencies and private industries can use to avoid, minimize, or mitigate the impacts of energy infrastructure on wildlife and their habitats.

Research goals range from identification of a specific local issue and options for response, to development of tools or techniques to address nationwide concerns. This scientific research furthers our understanding of existing and potential impacts and creates workable solutions. The three goals guiding USGS research are:

- Understand Risks: Identify when, where, and why wildlife shares space with energy facilities

- Measure Impacts: Assess direct and indirect impacts to species and populations

- Inform Solutions: Avoid or minimize impacts through technological fixes, management, and mitigation

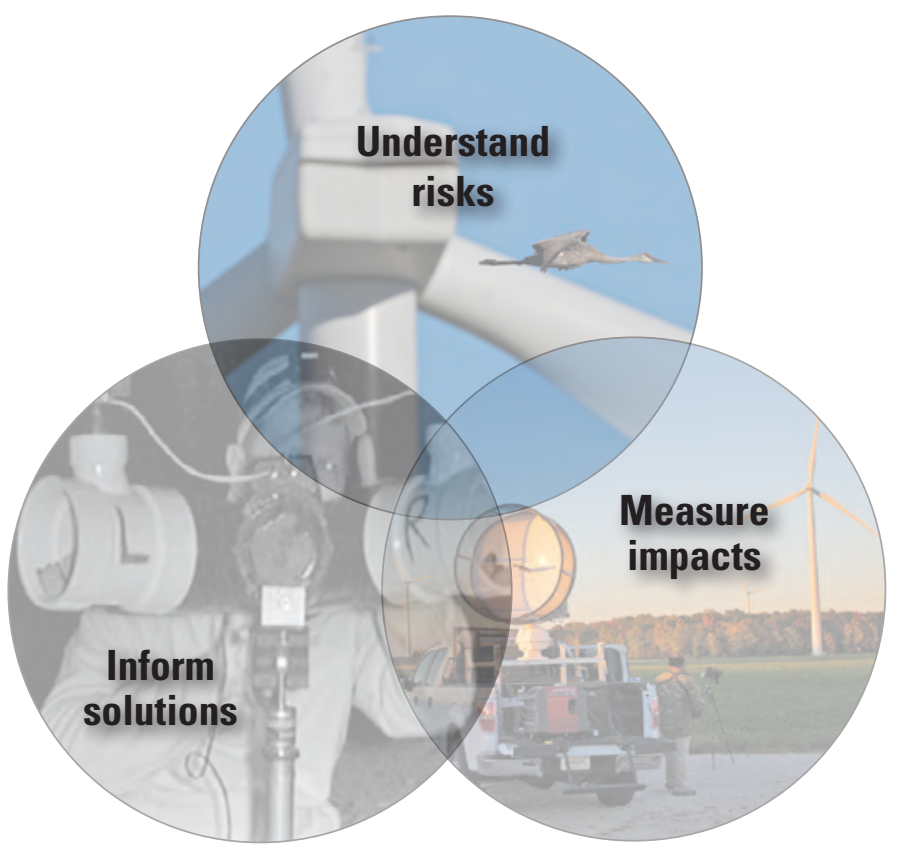

Three interrelated goals guiding USGS research in addressing energy and wildlife. 


\section{List of Projects}

Regulatory and management issues associated with energy development are often focused on the impacts on legally protected species and (or) other species and habitats of concern. The USGS research projects highlighted in this report are organized by species or groups of species, habitats, and other topics considered most relevant to the U.S. Fish and Wildlife Service (USFWS), Bureau of Land Management (BLM), Bureau of Ocean Energy Management (BOEM), and other agencies responsible for permitting energy projects, conserving or managing species and habitats, and monitoring operations of renewable or conventional energy facilities.

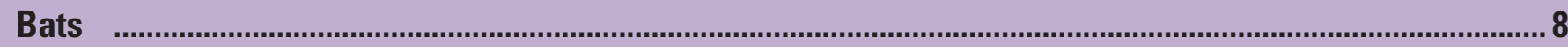

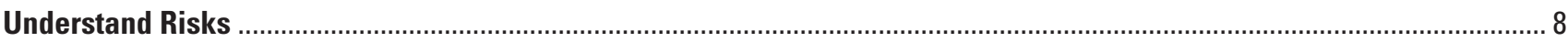

1. Understanding and Reducing Bat Fatalities Associated With Wind Turbines ........................................................... 8

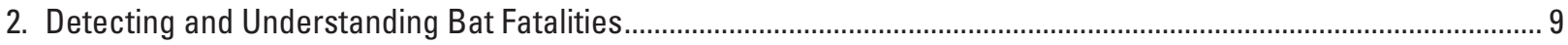

3. Acoustic and Ultrasonic Recorders Track Bird and Bat Flight Activity .................................................................. 9

4. Bat Activity in the Great Lakes and Implications for Wind Energy Development .......................................................

5. Migratory Corridors and Habitat Use by Bats Across Nebraska ..........................................................................

6. Pre- and Post-Hibernation and Migratory Activity of Bats in the Central Appalachians ......................................... 10

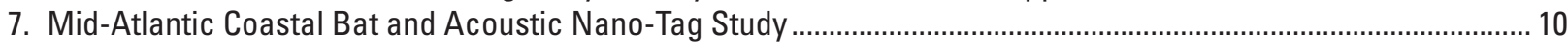

8. The North American Bat Monitoring Program (NABat) ....................................................................................... 10

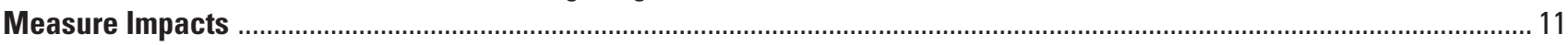

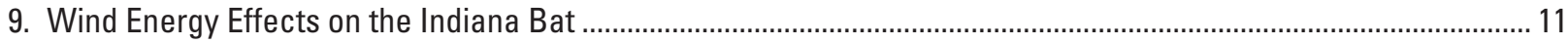

10. Using Genetic Tools to Examine the Biology of Summer-Roosting Indiana Bats .................................................. 11

11. Post-White-Nose Syndrome Assessment of Bat Distribution in the Mid-Atlantic and Northeast............................ 11

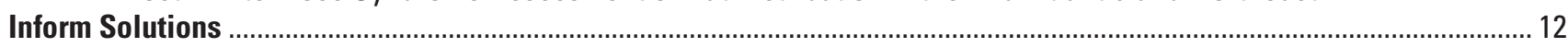

12. Ultraviolet Illumination as a Means of Reducing Bat Activity and Risk at Wind Turbines........................................ 12

13. Curtailment Strategies to Reduce Bat Fatalities .................................................................................................... 13

14. Comparing the Effectiveness of Ultrasonic Acoustic Deterrents to Operational Curtailment in Reducing Bat Fatalities..... 13

15. Optimizing Acoustic Detection of Bats to Monitor Flight Activity Near Wind Turbines ........................................... 13

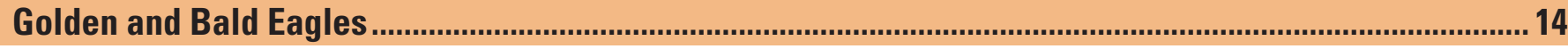

Understand Risks.

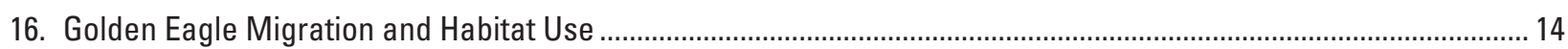

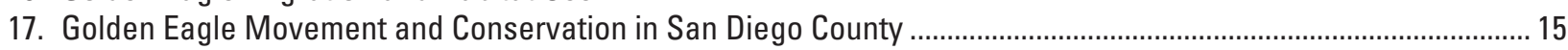

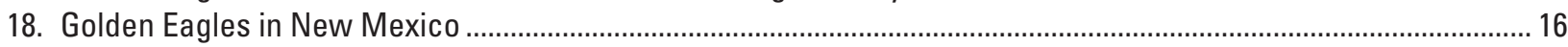

19. Tracking Bald Eagles Near Wind Energy Facilities in the Central Great Plains......................................................... 16

20. Assessing Eagle Use Frequency at Wind Energy Facilities .............................................................................. 16

21. Linking Habitat and Prey Availability to Golden Eagle Ecology in the Mojave Desert............................................... 16

22. Ecology of Leporids in the Western United States and Their Significance to Golden Eagles................................... 17

23. Wintering Distribution of Golden Eagles in the Southern Great Plains ................................................................... 17

24. Eagle Surveys, Monitoring, and Distribution ………………………………….............................................. 17

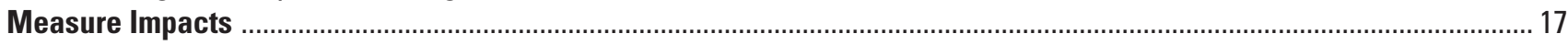

25. Golden Eagle Monitoring Protocol for the Desert Renewable Energy Conservation Plan ....................................... 17

26. Golden Eagles Around the Altamont Pass Wind Resource Area, California ............................................................ 18

27. Using Drones to Detect Golden Eagle Carcasses.................................................................................................... 18

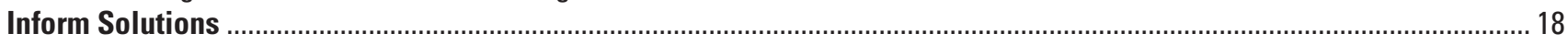

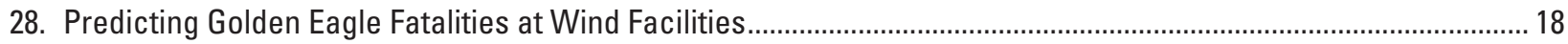

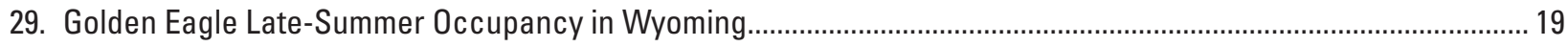

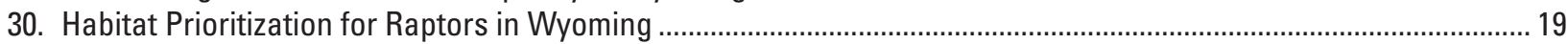

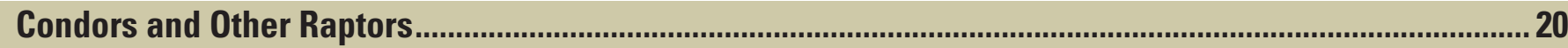

31. Raptor Density and Distributions in Southern California Deserts ............................................................................. 20

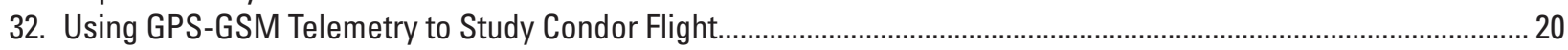

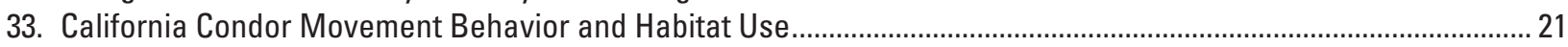

34. California Condor Space Use and Wind Resources ......................................................................................... 21

35. Potential Interactions of Migrating Raptors and Wind Energy Sites at the International Scale .............................. 22

36. Re-Occupancy of Breeding Territories by Ferruginous Hawks in Wyoming ............................................................. 22 
Great Lakes, Coastal, and Marine Birds 23

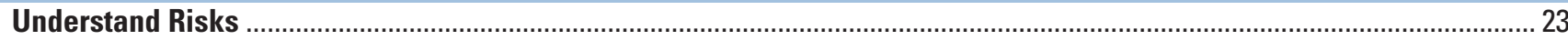

37. Statistical Guidelines for Sampling of Marine Avian Populations........................................................................ 23

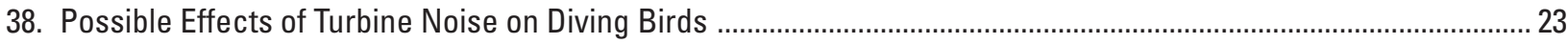

The Great Lakes

39. Monitoring and Mapping Avian Resources in Nearshore and Open Waters of Lake Michigan ............................... 24

40. Documenting Movements, Habitat Use, and Foraging Patterns of Common Loons ................................................... 24

41. Airspace Use by Migrating Landbirds at Lake Erie ................................................................................................... 24

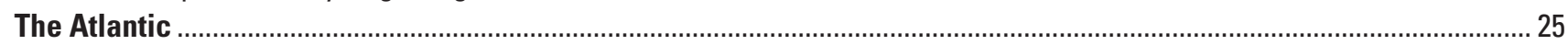

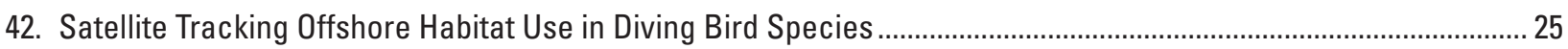

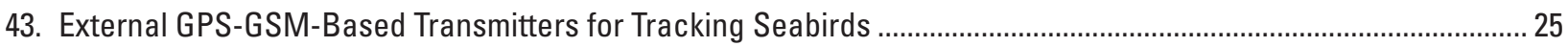

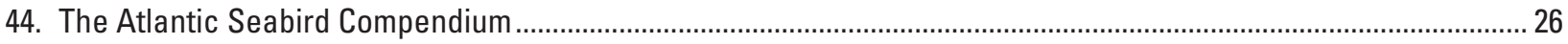

45. Modeling of Atlantic Coast Seabird Distributions........................................................................................... 26

46. Potential Impacts of Offshore Wind Energy Projects on Endangered Roseate Terns ............................................ 26

47. Survey of Biological Hotspots in the Gulf of Maine Coastal Marine Ecosystem ......................................................... 27

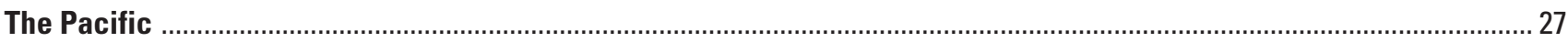

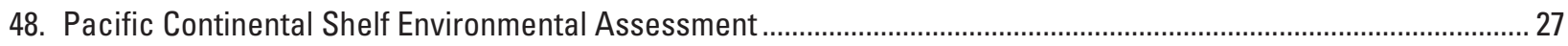

49. Seabird Vulnerability Assessment for Renewable Energy Projects .......................................................................... 27

50. Predictive Modeling of Marine Bird Spatial Distributions on the Pacific Outer Continental Shelf .......................... 28

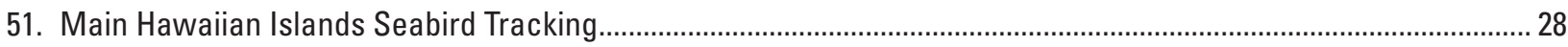

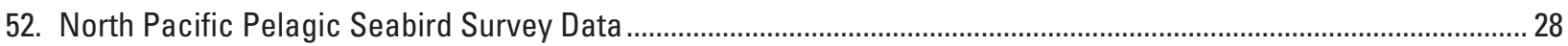

53. Status of Seabirds and Forage Fish in Cook Inlet, Alaska ................................................................................. 28

54. Integrated Predator-Prey Surveys: Humpback Whales, Marine Birds, Forage Fish ................................................... 29

The Gulf of Mexico

55. Spatial and Reproductive Ecology of Brown Pelicans in the Gulf of Mexico ............................................................ 29

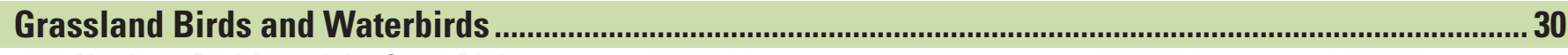

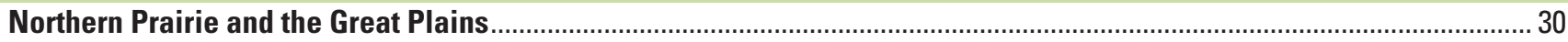

56. Direct Mortality to Avifauna From Wind Energy Facilities in the Dakotas................................................................. 30

57. Wind Energy Effects on Distribution of Grassland Birds in the Dakotas ............................................................... 30

58. Avoidance of Oil Wells and Roads Exacerbates Habitat Loss for Grassland Birds ................................................... 31

59. Birds and the Bakken Formation: Integration of Oil Well, Land Cover, and Species Distribution Data to Inform Conservation ...31

60. Lesser Prairie-Chicken Population and Habitat Ecology ........................................................................................ 31

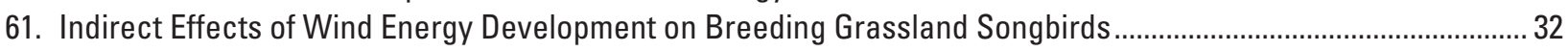

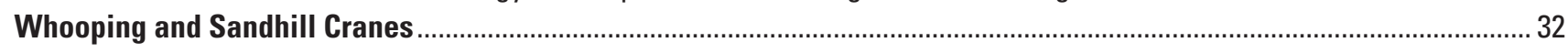

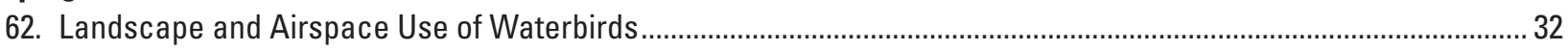

63. Whooping Crane Stopover Site Use Intensity Within the Great Plains.................................................................. 33

64. Sandhill Crane Exposure to Wind Energy Development in the Great Plains ................................................................ 33

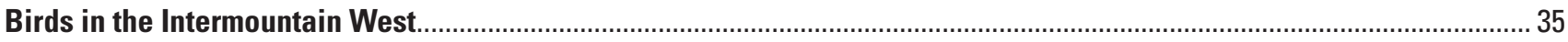

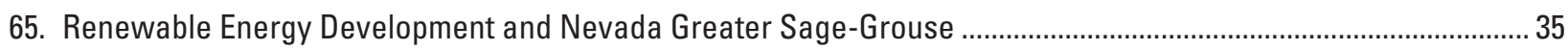

66. Implications of Anthropogenic Activities on Greater Sage-Grouse Populations in Nevada....................................35

67. Breeding Sagebrush Songbird Responses to Gas Development: Patterns and Mechanisms....................................36

68. Greater Sage-Grouse Responses to Climate Change and Future Energy Development in Wyoming ...................... 37

69. Investigating the Impacts of Oil and Gas Development on Greater Sage-Grouse by Using a Bayesian State-Space Model ......37

70. Conservation Buffer Distance Estimates for Greater Sage-Grouse-A Review........................................................ 37

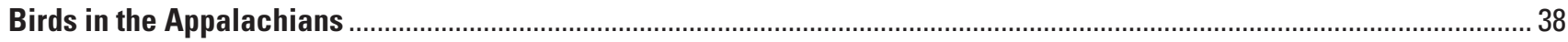

71. Shale Gas Development Effects on Songbirds in Central Appalachia ................................................................... 38

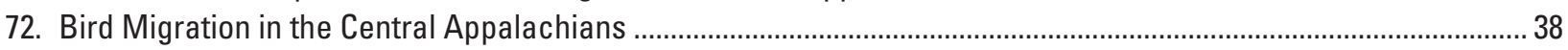

73. Reproductive Success and Habitat Use on Reclaimed Surface Mines................................................................... 38

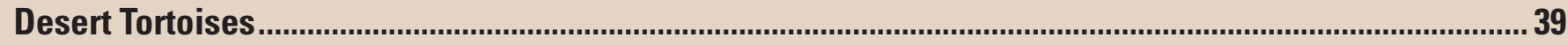

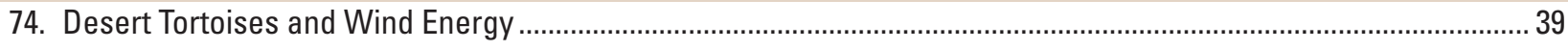

75. Effects of Solar Development and Habitat Alterations on Desert Tortoises in the Ivanpah Valley ........................... 40

76. Desert Tortoise Annotated Bibliography .............................................................................................................. 40 
Pollinators.

77. Impact of Biofuel Crop Production on Pollinators in the Northern Great Plains ...................................................... 41

78. Taxonomic Characterization of Honey Bee Pollen Foraging .................................................................................. 41

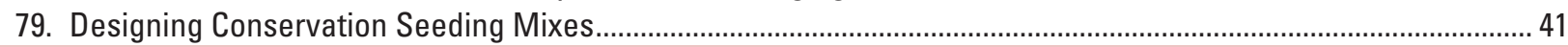

Other Species..................................................................................................................................................... 42

80. Canid Distribution and the Potential Impacts of Energy Development in Nebraska............................................... 42

81. Quantifying Exposure of Wildlife to Oil, Gas, and Wind Energy Development....................................................... 42

82. Land Use and Microhabitat Effects on Salamanders in the Central Appalachian Coal Fields ............................... 43

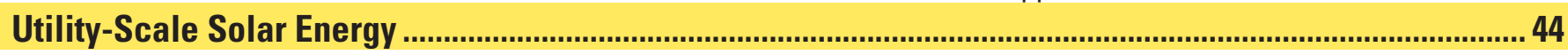

83. Efficacy of Wildlife Monitoring Technologies at a Solar Tower Facility.................................................................. 44

84. Fatality Monitoring Design for Utility-Scale Solar Power Facilities ....................................................................... 44

85. Climate Change, Conservation Planning, and Renewable Energy Development in the Mojave Desert.................. 45

86. Solar-Facility Fatality Estimator and Evidence of Absence Software .......................................................................... 45

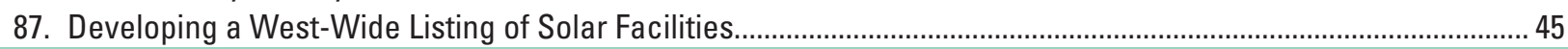

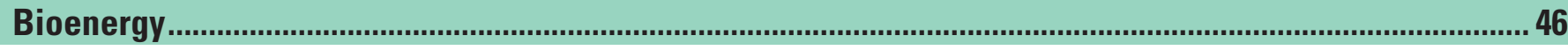

88. Bioenergy Production and Landscape Change in the Southeastern United States ............................................ 46

89. Potential Impacts of Switchgrass Production on Grassland Birds............................................................................ 47

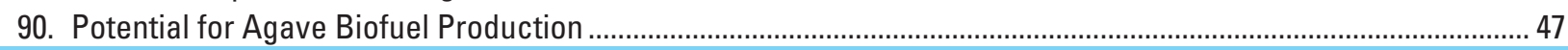

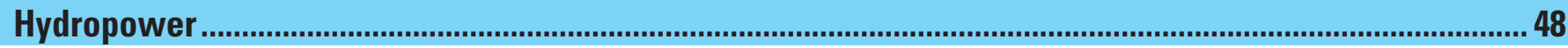

91. Fish Passage and Survival Through Diversion Dams .................................................................................... 48

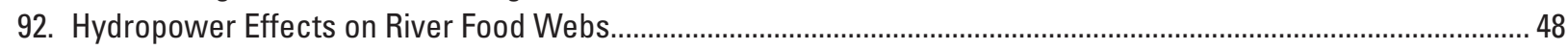

93. Structured Decisionmaking for the Management of Glen Canyon Dam .................................................................. 49

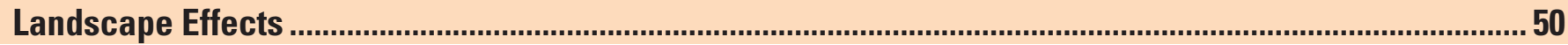

94. Habitat Connectivity Study Describes a Framework for Conserving At-Risk Species .......................................... 50

95. Habitat Suitability and Climate Change Modeling to Inform Renewable Energy Development .............................. 50

96. Landscape-Scale Measures of Genetic Diversity Assist in Siting Renewable Energy Facilities..............................51

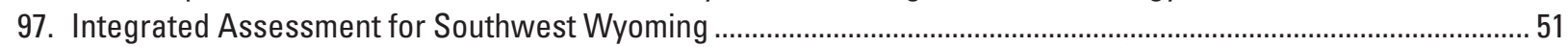

98. Wyoming Wind Energy Disturbance Mapping .................................................................................................. 51

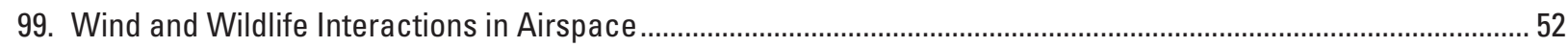

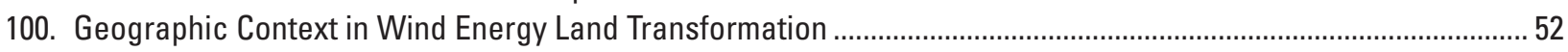

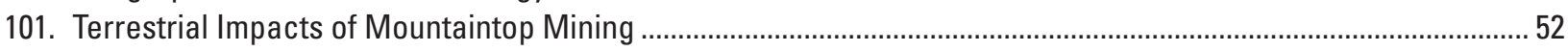

102. Ecological Effects of Brine Contamination From Energy Production in the Prairie Pothole Region ........................ 53

103. Land-Cover Changes Associated With Recent Energy Development in the Williston Basin..................................53

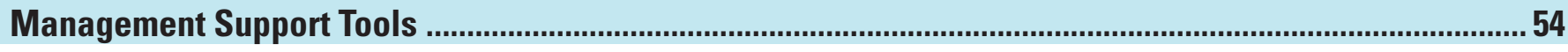

Understand Risks.

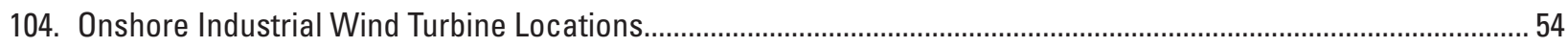

105. Pre-Construction Assessment: Bird and Bat Risk From Wind Development—A Review........................................54

106. Sensitive and Rare Plant Distributions and Energy Development in the Colorado Plateau ....................................55

Measure Impacts

107. Tools to Help Assess Energy Development Impacts to Sensitive Birds and Bats.................................................. 55

108. Post-Construction Assessment of Risk to Birds and Bats From Wind Energy—A Review ....................................55

109. Estimates of Avian Fatalities at Wind Energy Facilities in the United States-A Review...........................................56

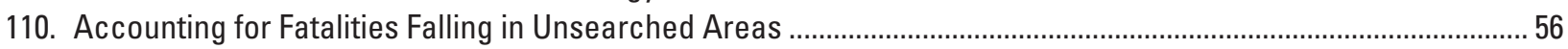

111. Estimating Wildlife Mortality From Collisions With Structures................................................................................ 56

112. Evidence of Absence or Absence of Evidence? .............................................................................................. 56

113. Estimation of Bird and Bat Mortality at Wind-Power Farms With Super-Population Models.................................57

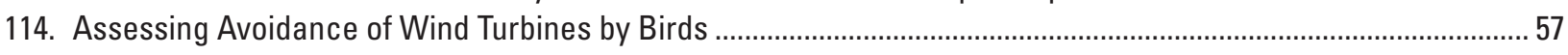

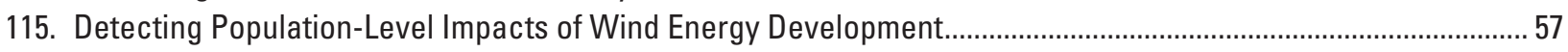

116. Wind Energy Impacts Assessment Methodology Project....................................................................................... 58

Inform Solutions

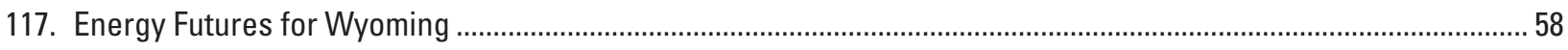

118. Informing Energy Development Siting Decisions With Vertebrate Biodiversity Measures....................................... 59 


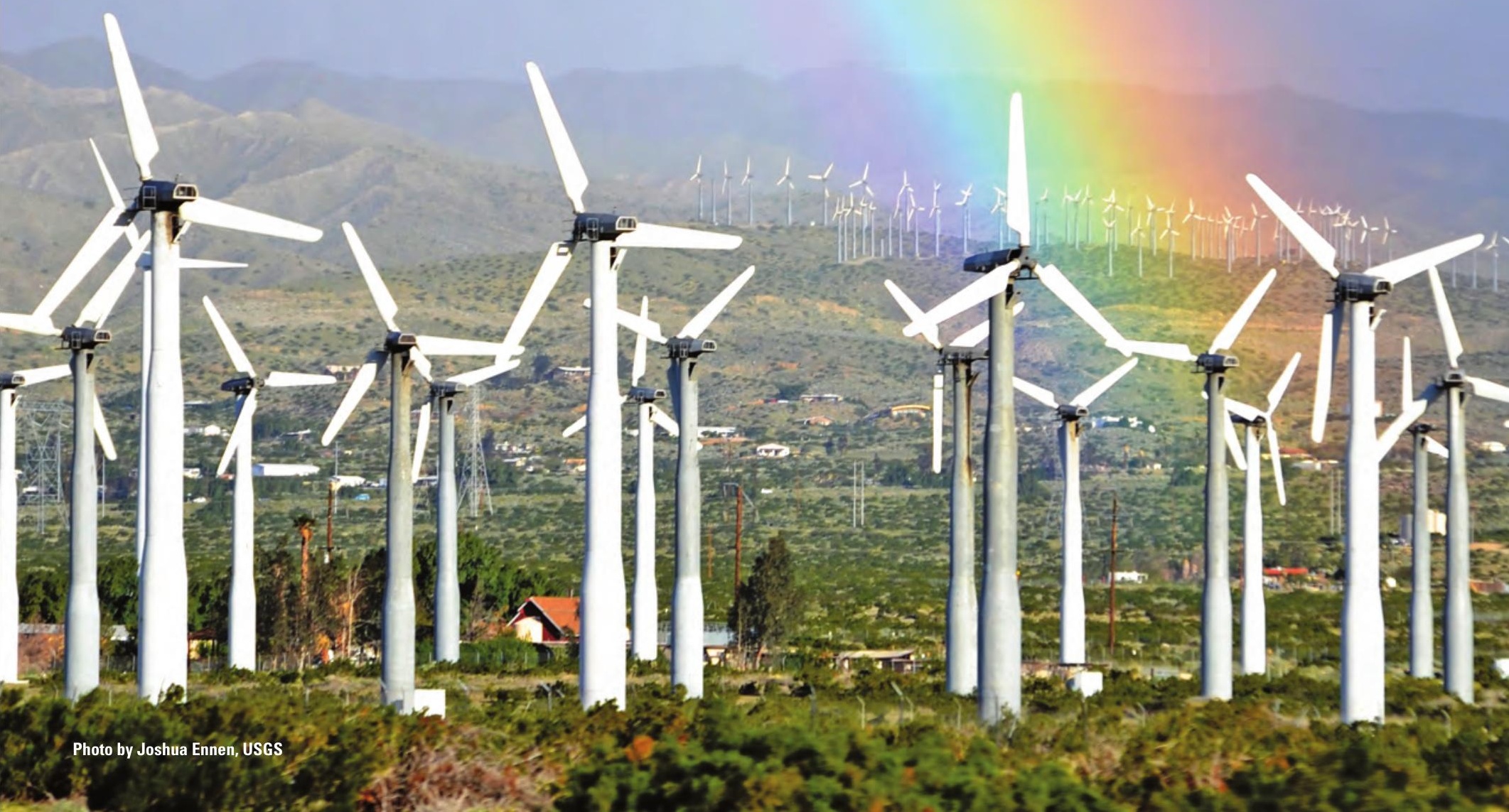




\section{Study Locations}

50

48

49
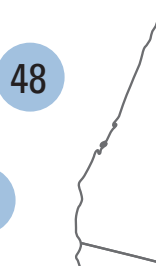



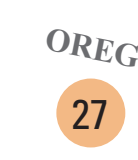

27.

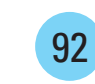

92

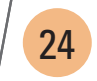

24.

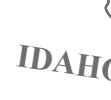

IDAHO
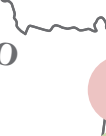

81

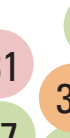

70

70

\begin{tabular}{crr} 
& 69 & 98 \\
30 & WYOMING \\
& 117 & 36 \\
\hline
\end{tabular}

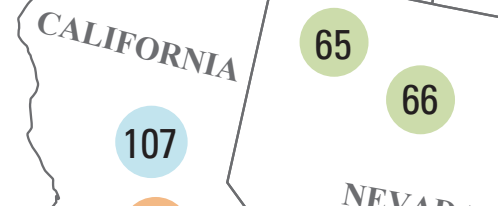

26 NEVADA

$16 \quad 92$

$32 \quad 3420$

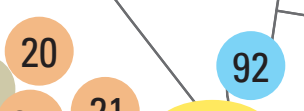

32

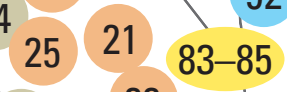

$31,22^{83-85}$
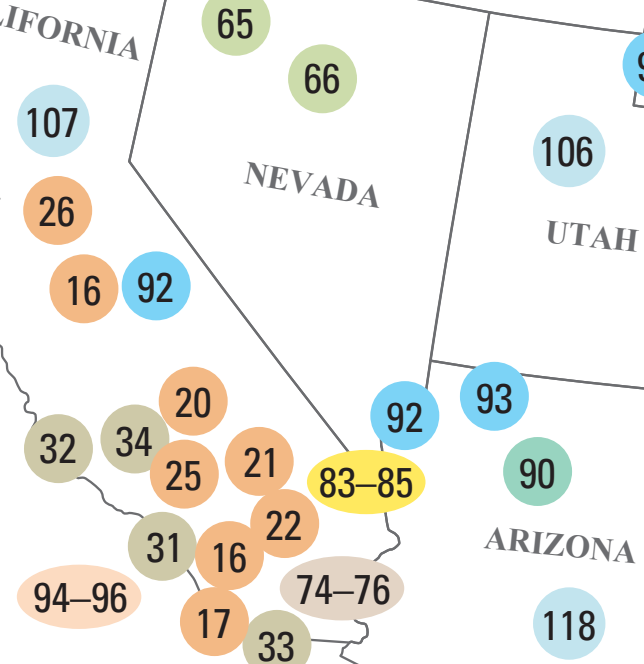

92

$2 4 \longdiv { 2 9 }$

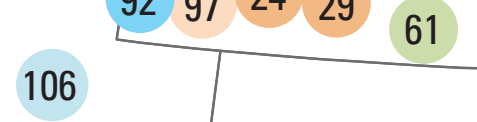

\section{9}

$8 9 \longdiv { 5 }$

80 NEBRASKA
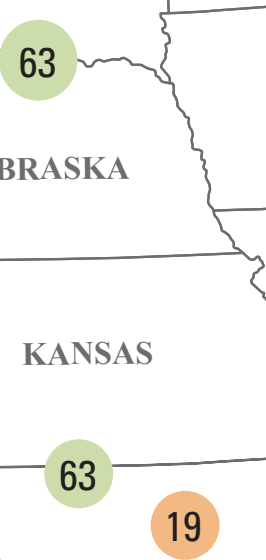

64

90

$B$

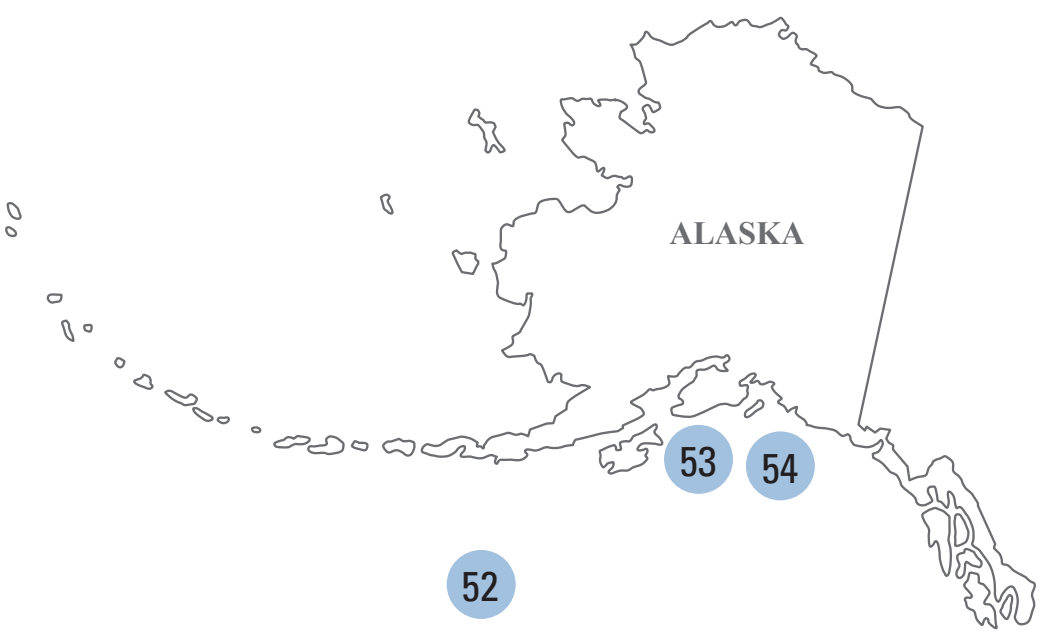

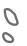
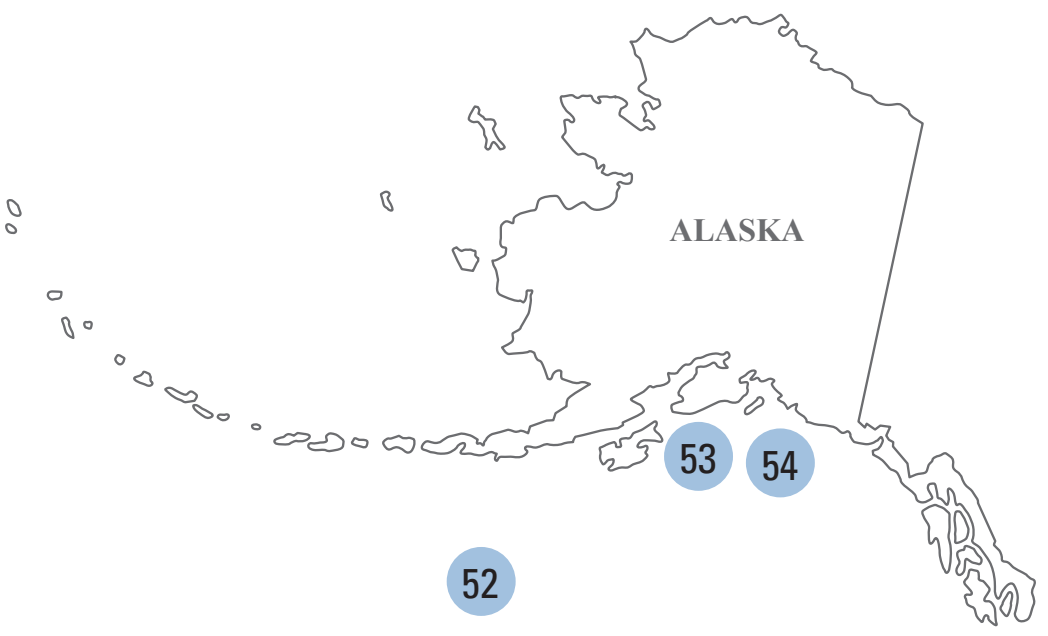

18

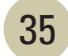

TEXAS

63

2
.0

(51) in o : HAWAII 12 


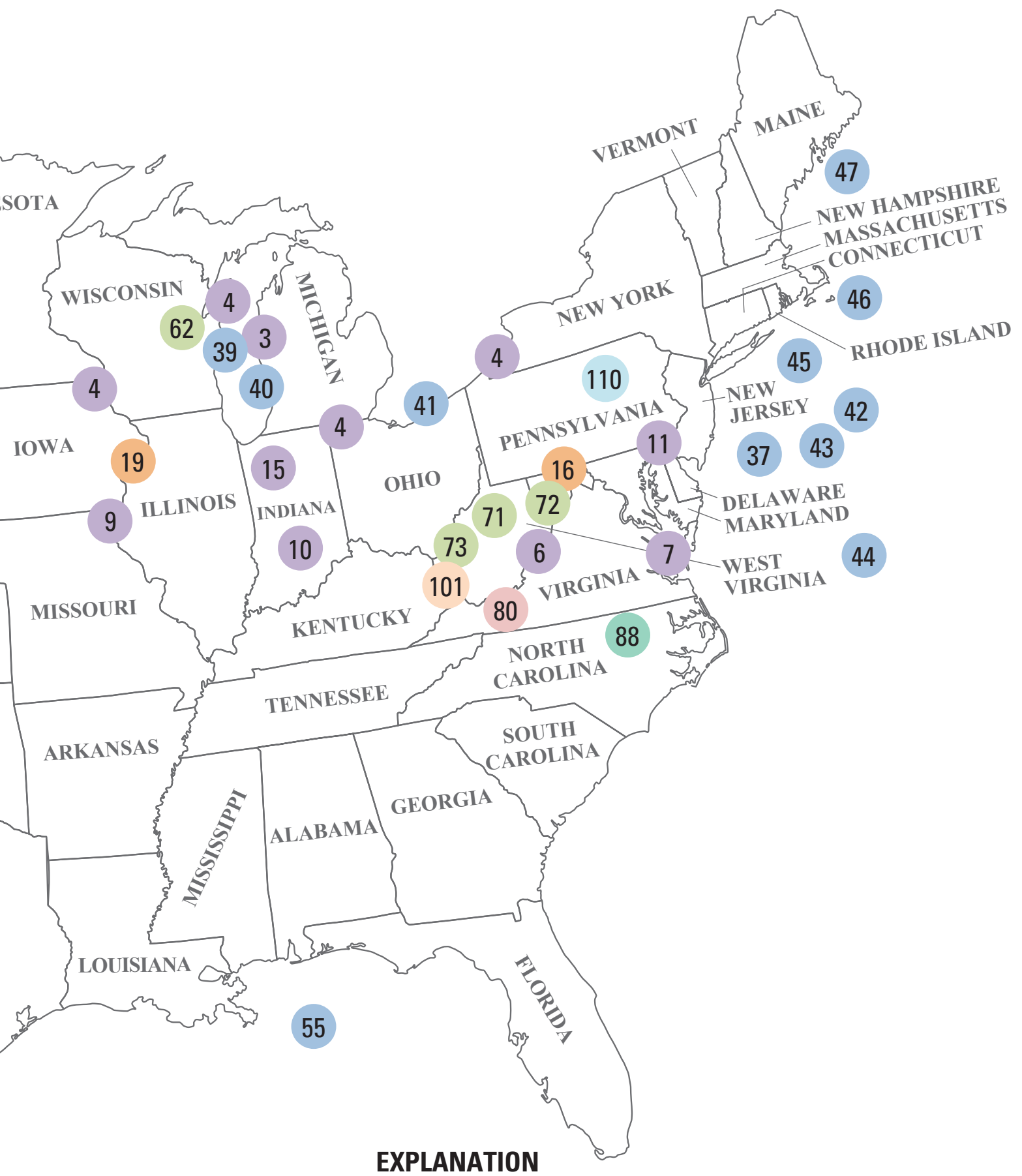

U.S. Geological Survey Energy and Wildlife project with a specific geographic, Tribal lands, or State focus-Number in circle corresponds to project number (page 2). Project numbers associated with each research topic are shown in parentheses. Not all projects are shown on the map

Bats (1-15)

Golden and bald eagles (16-30)

Condors and other raptors (31-36)

Great Lakes, coastal, and marine birds (37-55)
Grassland birds and waterbirds (56-73)

Desert tortoise (74-76)

Pollinators (77-79)

Other species (80-82)

Utility-scale solar energy (83-87)
Bioenergy (88-90)

Hydropower (91-93)

Landscape effects

(94-103)

Management support tools (104-118) 


\section{Project Descriptions}

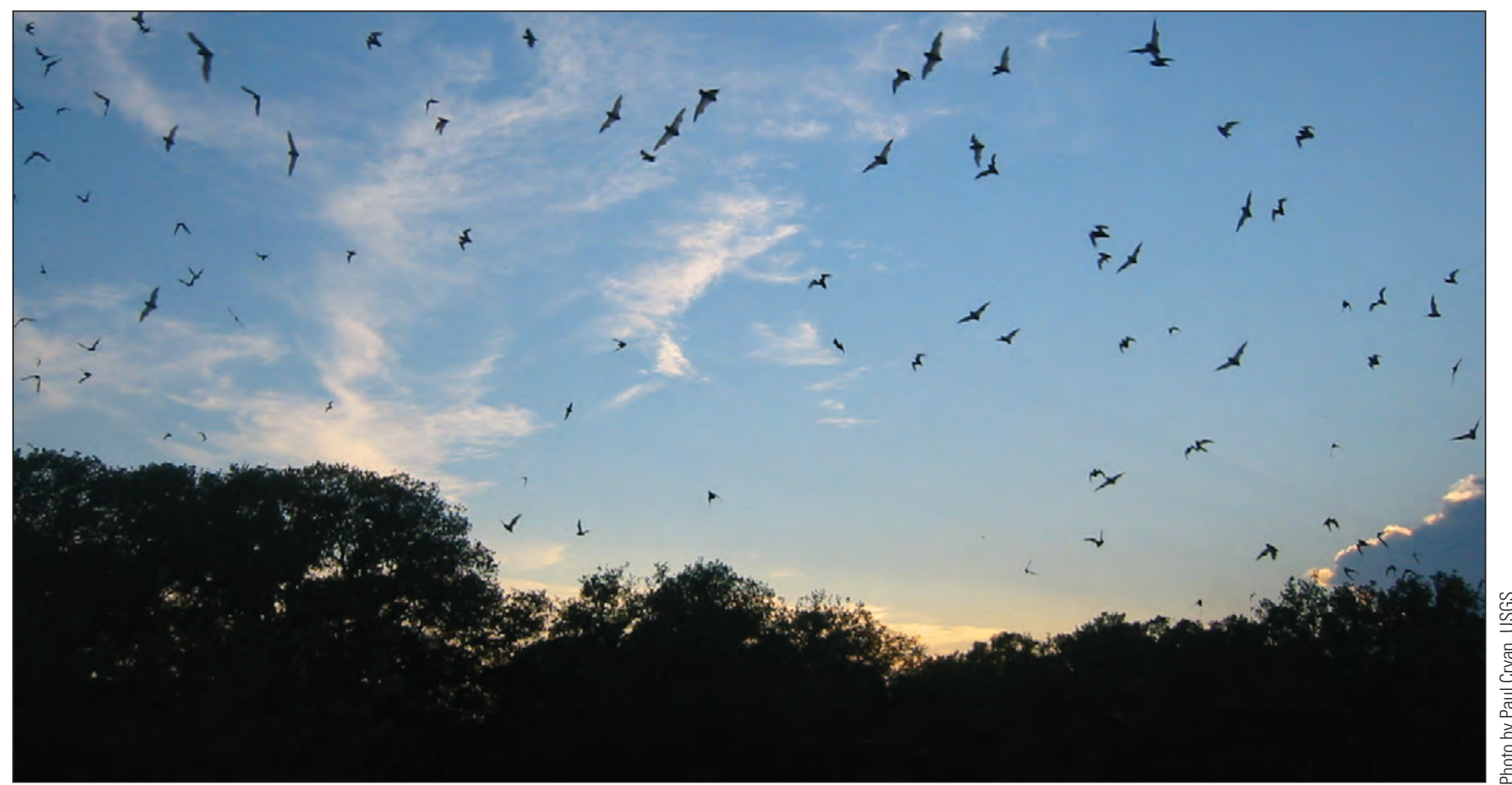

Bat colony flying at dusk.

\section{Bats}

\section{Understand Risks}

\section{Understanding and Reducing Bat Fatalities Associated With Wind Turbines}

Migratory bat species that roost in trees, or tree bats, are disproportionately affected by wind turbines, in part because they appear to be attracted to these structures. USGS research has led to new discoveries about these species, such as the consistent patterns in the way tree bats approach and dangerously interact with turbines at night (for example, making extremely close approaches on the downwind side of these structures), and identified areas of the continent where risk might be higher (such as the Great Plains, the Great Lakes region, and areas adjacent to coastal wintering areas). Working from this foundation, current USGS research aims to apply understanding of bat behaviors, seasonal distribution, and perception toward efficient and effective ways of reducing bat interactions with wind turbines.

\section{Contact}

Paul Cryan, USGS Fort Collins Science Center; cryanp@usgs.gov; (970) 226-9389

\section{Publications}

Castle, K.T., Weller, T.J., Cryan, P.M., Hein, C.D., and Schirmacher, M.R., 2015, Using sutures to attach miniature tracking tags to small bats for multimonth movement and behavioral studies: Ecology and Evolution, v. 5, no. 14, p. 2980-2989, http://dx.doi.org/10.1002/ece3.1584.

Cryan, P.M., Gorresen, P.M., Hein, C.D., Schirmacher, M.R., Diehl, R.H., Huso, M.M., Hayman, D.T.S., Fricker, P.D., Bonaccorso, F.J., Johnson, D.H., Heist, Kevin, and Dalton, D.C., 2014, Behaviors of bats at wind turbines: Proceedings of the National Academy of Sciences, v. 111, no. 42, p. 15126-15131, http://dx.doi.org/10.1073/pnas.1406672111.

Cryan, P.M., Stricker, C.A., and Wunder, M.B., 2014, Continental-scale, seasonal movements of a heterothermic migratory tree bat: Ecological Applications, v. 24, no. 4, p. 602-616, http://dx.doi.org/10.1890/13-0752.1.

Hayes, M.A., Cryan, P.M., and Wunder, M.B., 2015, Seasonally-dynamic presence-only species distribution models for a cryptic migratory bat impacted by wind energy development: PLOS ONE, v. 10, no. 7, p. e0132599, http://dx.doi.org/10.1371/journal.pone.0132599.

Hayes, M.A., Ozenberger, Katharine, Cryan, P.M., and Wunder, M.B., 2015, Not to put too fine a point on it—does increasing precision of geographic referencing improve species distribution models for a wide-ranging migratory bat?: Acta Chiropterologica, v. 17, no. 1, p. 159-169, http://dx.doi.org/10.3161/15081109ACC2015.17.1.013.

O'Shea, T.J., Cryan, P.M., Hayman, D.T.S., Plowright, R.K., and Streicker, D.G., 2016, Multiple mortality events in bats—A global review: Mammal Review, v. 46, no. 3, p. 175-190, http://dx.doi.org/10.1111/mam.12064. 


\section{Detecting and Understanding Bat Fatalities}

A USGS study conducted on north Oahu, Hawaii, simultaneously monitored bats at turbines with thermal and near-infrared cameras and nacelle-mounted acoustic detectors. Bats were more likely to be found near turbines when barometric pressure was low but rising, as well as during periods of low wind and warmer temperatures. Nightly insect and bat detections were significantly and positively correlated. This correspondence between bat and insect presence may be a relatively simple predictor of bat activity and could help refine curtailment strategies.

\section{Contact}

Marcos Gorresen, Hawaii Cooperative Studies Unit at the University of Hawaii at Hilo and USGS Pacific Islands Ecosystems Research Center; mgorresen@usgs.gov; (808) 985-6407

\section{Publication}

Gorressen, P.M., Cryan, Paul, Huso, Manuaela, Hein, Cris, Schirmacher, Michael, Johnson, Jessica, Montoya-Aiona, Kristina, Brinck, Kevin,

and Bonaccorso, Frank, 2015, Behavior of the Hawaiian hoary bat (Lasiurus cinereus semotus) at wind turbines and its distribution across the North Ko'olau mountains, O’ahu: Hilo, Hawaii, University of Hawaii at Hilo, Technical Report HCSU-064, 68 p., http://hdl.handle.net/10790/2585.

\section{Acoustic and Ultrasonic Recorders Track Bird and Bat Flight Activity}

The USGS and collaborators are using acoustic and ultrasonic recorders to monitor flight notes of birds and calls emitted by bats flying at low altitudes. Recorders, deployed at numerous locations along the shores of several of the Great Lakes, are used to estimate low-altitude flight activity of birds and bats, especially during migration periods, at sites where wind development appears likely. Objectives are to determine whether the recorders can be used to compare low-altitude flight activity among sites and to relate recorder results to numbers of dead birds and bats found at wind facilities.

\section{Contact}

Douglas H. Johnson, USGS Northern Prairie Wildlife Research Center; douglas_h_johnson@usgs.gov; (612) 624-4716

\section{Bat Activity in the Great Lakes and Implications for Wind Energy Development}

To examine bat activity and evaluate possible impacts from wind energy development in the Upper Midwest, the USGS and collaborators are monitoring 147 sites using acoustic recorders during periods of bat migration, both near the Great Lakes coasts and at inland areas throughout the Midwest. Activity recorded by ground-based detectors may help identify areas of high and low risk to bats from wind energy development.

Contact

Douglas H. Johnson, USGS Northern Prairie Wildlife Research Center; douglas_h_johnson@usgs.gov; (612) 624-4716

\section{Migratory Corridors and Habitat Use by Bats Across Nebraska}

Nebraska's vast wind resources are well suited for wind energy facilities. The potential negative impacts to Nebraska's wildlife and agriculture industry could be substantial if these resources are not considered when evaluating projects or developing siting criteria. For example, bats play a key ecological role in maintaining healthy ecosystems throughout Nebraska but are extremely vulnerable to wind projects. To address this issue, the USGS is conducting research to better understand the habitats and conditions that affect bat presence, activity, movement, and migration. By examining the activity of bats throughout the year, researchers hope to identify migratory patterns related to weather and landscape features. The results could help utility companies, wind energy developers, and facility owners avoid, manage, and mitigate the potential negative consequences of wind energy facilities.

Contact

Craig Allen, USGS Nebraska Cooperative Fish and Wildlife Research Unit; allencr@usgs.gov; (402) 472-0229 


\section{Pre- and Post-Hibernation and Migratory Activity of Bats in the Central Appalachians}

The USGS and Virginia Polytechnic Institute and State University are using fixed-site, long-term acoustical monitoring near cave systems and along mountain ridgelines and adjacent side slopes in Virginia and West Virginia to determine the timing of hibernation entry and exit and associated swarm-area habitat use for the endangered Indiana bat (Myotis sodalis) and threatened northern long-eared bat (Myotis septentrionalis). Additionally, this project is being conducted to examine the timing and location of migratory pulses for eastern red bats (Lasiurus borealis). These data can be used to inform siting criteria for proposed wind energy facilities to lessen the potential impacts on migratory bats that use Appalachian ridges as their primary migration corridors as well as to understand the potential risks for myotid bats making short-distance movements to swarm habitats in the fall and post-hibernation and maternity habitats in the spring.

Contact

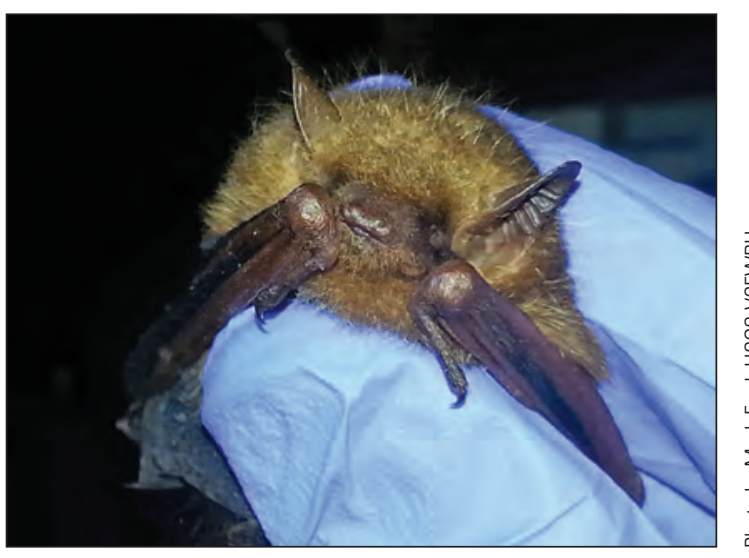

Northern long-eared bat, Rock Creek Park, Md.

Mark Ford, USGS Virginia Cooperative Fish and Wildlife Research Unit; wmford@vt.edu; (540) 231-5927

\section{Mid-Atlantic Coastal Bat and Acoustic Nano-Tag Study}

The Virginia Department of Game and Inland Fisheries, the USGS, and Virginia Polytechnic Institute and State University are studying migration timing and habitat use of eastern red bats in coastal areas of Virginia. With the move to develop coastal wind energy resources, there is a need to understand the potential for migration disruption and possible additive mortality of red bats and other migratory species. By understanding the timing of migration and offshore movements of these bats, it may be possible to design and implement wind energy mitigation measures, such as seasonal curtailment and (or) siting, to minimize interactions with bats. Red bats will be captured along the coast in Virginia, Maryland, and New Jersey prior to fall migration and in Virginia prior to spring migration and outfitted with very high frequency nano-tags. Fixed sensor towers capable of tracking multiple bats simultaneously are being placed along the Virginia outer coast and in the Chesapeake Bay.

Contact

Mark Ford, USGS Virginia Cooperative Fish and Wildlife Research Unit; wmford@vt.edu; (540) 231-5927

\section{The North American Bat Monitoring Program (NABat)}

North American bats face unprecedented risks from continuing and emerging threats and are experiencing unparalleled population declines. To better understand the ecological consequences of these large-scale population reductions, the USGS is leading the development and implementation of a multiorganizational North American Bat Monitoring Program (NABat). NABat is focused on the 47 species of bats that inhabit and migrate through Canada, the United States, and Mexico. The goal of NABat is to help resource managers detect early signs of population declines, better estimate extinction risk, establish conservation priorities, and evaluate the effectiveness of conservation actions.

NABat goals are to:

- provide staffing and information technology infrastructure to support a coordinated bat monitoring program across Tribal/aboriginal, national, State, provincial, and private land boundaries,

- create a statistically robust sampling design and standardized monitoring protocols,

- work with partners to collect data in the field, and

- provide statistical analyses and interpretation of bat population data at continental, national, and regional scales.

Currently, data management for the NABat program is provided by the USGS. A NABat advisory committee is composed of representatives from the U.S. Forest Service, USFWS, USGS, National Park Service (NPS), Canadian Wildlife Service, Canadian Wildlife Health Cooperative, Bat Conservation International, and Wildlife Conservation Society Canada.

Contact

Patricia Stevens, USGS Fort Collins Science Center; stevensp@usgs.gov; (970) 226-9499 


\section{Measure Impacts}

\section{Wind Energy Effects on the Indiana Bat}

The USGS developed a quantitative framework for understanding the effects of wind energy development on migratory bats by developing migratory connectivity models for the endangered Indiana bat. Using USFWS data to determine model parameters, this framework provides insight into the effects of wind energy on migratory patterns and spatial dynamics of bats and also examines the synergistic effects of white-nose syndrome (WNS) on bat mortality. Wind energy development and WNS affect bat populations differently. Wind energy development disproportionately affects small overwintering populations, whereas WNS will more likely extirpate large overwintering populations. These findings illustrate the importance of considering changes among groups of populations when managing the Indiana bat.

Contact

Wayne Thogmartin, USGS Upper Midwest Environmental Sciences Center; wthogmartin@usgs.gov; (608) 781-6309

Publications

Erickson, R.A., Eager E.A., Stanton J.C., Beston J.A., Diffendorfer J.E., and Thogmartin, W.E., 2015, Assessing local population vulnerability with branching process models - An application to wind energy development: Ecosphere, v. 6, no. 12, art254, 14 p., http://dx.doi.org/ 10.1890/es15-00103.1. [For more details, see https://sites.google.com/a/uwlax.edu/eric-eager/service/university-of-wisconsin---la-crossemath-bio-working-group.]

Erickson, R.A., Thogmartin, W.E., Russell, R.E., Diffendorfer, J.E., and Szymanski, J.A., 2014, A stage-structured, spatially explicit migration model for Myotis bats-Mortality location affects system dynamics: Letters in Biomathematics v. 1, no. 2, p. 157-172, http://dx.doi.org/ 10.1080/23737867.2014.11414477. [Code available at https://github.com/USGS-R/BatTool.]

\section{Using Genetic Tools to Examine the Biology of Summer-Roosting Indiana Bats}

Indiana bats are at risk from wind turbines, and wide-range populations of Indiana bats have declined by approximately half since 1967 when the species was listed as endangered under the Endangered Species Act. Traditional tracking techniques have not enabled researchers to regularly monitor individual bats throughout a field season. Recent advances in genetic techniques have made it possible to uniquely identify animals using deoxyribonucleic acid (DNA) in mark-recapture studies. Preliminary work by the USGS has shown that DNA can be extracted from Indiana bat fecal pellets collected beneath roost trees. It is now possible to explore the relatedness of Indiana batcolony members using genetic information and to estimate population sizes using DNA. Accurate demographic and relatedness information can assist conservation managers in the management and recovery of the Indiana bat.

Contact

Sara Oyler-McCance, USGS Fort Collins Science Center;

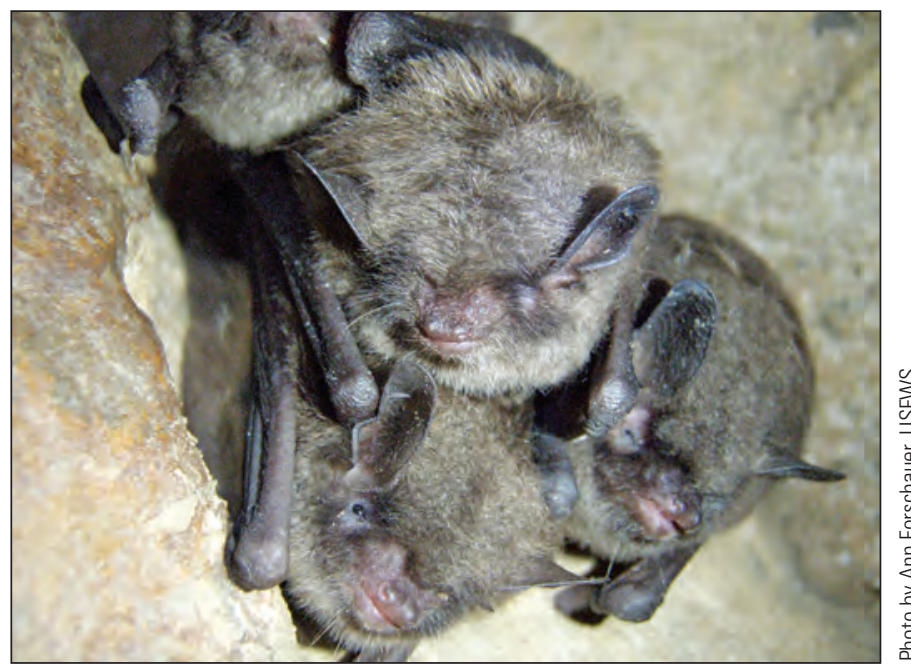

Indiana bats. sara_oyler-mccance@usgs.gov; (970) 226-9197

\section{Post-White-Nose Syndrome Assessment of Bat Distribution in the Mid-Atlantic and Northeast}

The USGS and Virginia Polytechnic Institute and State University, in cooperation with the USFWS, the National White-Nose Syndrome (WNS) Program, and the U.S. Army, are using multiyear acoustic data from more than 1,200 locations from the Appalachian Mountains to the Atlantic Coast, and from Virginia to New England, to determine post-WNS distribution and the community structure of bats. These data are being used to model current and future potential occupancy from individual forest to landscape level. Results can be used to inform managers and regulators of the likelihood that a rare, threatened, or endangered bat species will be found in or near wind energy development, surface mining, or oil and gas development activities on public lands. This project will also provide information on the level of effort required for acoustic monitoring of the endangered Indiana bat and threatened northern long-eared bat.

Contact

Mark Ford, USGS Virginia Cooperative Fish and Wildlife Research Unit; wmford@vt.edu; (540) 231-5927 


\section{Publications}

Coleman, L.S., Ford, W.M., Dobony, C.A., and Britzke, E.R., 2014, A comparison of passive and active acoustic sampling for a bat community impacted by white-nose syndrome: Journal of Fish and Wildlife Management, v. 5, no. 2, p. 217-226, http://dx.doi.org/ 10.3996/082013-jfwm-057.

Coleman, L.S., Ford, W.M., Dobony, C.A., and Britzke, E.R., 2014, Effect of passive acoustic sampling methodology on detecting bats after declines from white-nose syndrome: Journal of Ecology and the Natural Environment, v. 6, no. 2, p. 56-64, http://dx.doi.org/10.5897/ jene2013.0424.

Ford, W.M., Silvis, Alexander, Rodrigue, J.L., Kniowski, A.B. and Johnson, J.B., 2016, Deriving habitat models for northern long-eared bats from historical detection data-A case study using the Fernow Experimental Forest: Journal of Fish and Wildlife Management, v. 7, no. 1, p. 86-98, http://dx.doi.org/10.3996/012015-jfwm-004.

Powers, K.E., Reynolds, R.J., Orndorf, Wil, Ford, W.M., and Hobson, C.S., 2015, Post-white-nose syndrome trends in Virginia's cave bats, 2008-2013: Journal of Ecology and the Natural Environment, v. 7, no. 4, p. 56-64, http://dx.doi.org/10.5897/jene2015.0507

Reynolds, R.J., Powers, K.E., Orndorff, Wil, Ford, W.M., and Hobson, C.S., 2016, Changes in rates of capture and demographics of Myotis septentrionalis (northern long-eared bat) in Western Virginia before and after onset of white-nose syndrome: Northeastern Naturalist, v. 23, no. 2, p. 195-204, http://dx.doi.org/10.1656/045.023.0201.

\section{Inform Solutions}

\section{Ultraviolet Illumination as a Means of Reducing Bat Activity and Risk at Wind Turbines}

Insectivorous bats are known for their ability to find and pursue flying insect prey at close range by using echolocation, but they also rely heavily on vision. Using a cue that only bats might perceive, the USGS hopes to prevent bats from approaching wind turbines that might be mistaken for trees. In 2014, USGS scientists experimentally tested the ability of wild insectivorous bats to detect dim ultraviolet (UV) light and whether dim UV light could reduce bat activity. The scientists first confirmed that several species of bats were capable of detecting dim UV light. They then showed that Hawaiian hoary bat activity could be reduced in areas frequented by bats by illuminating trees with dim UV light. An operational turbine was subsequently illuminated with dim UV light prototypes and there was no indication of problems with the operations of the turbine when using this technique. Further research may determine whether dim UV light can reduce bat activity and fatality at operational wind farms, with the potential benefit of allowing operators to run turbines at maximum efficiency.

\section{Contacts}

Paul Cryan, USGS Fort Collins Science Center; cryanp@usgs.gov; (970) 226-9389

Marcos Gorresen, Hawaii Cooperative Studies Unit at the University of Hawaii at Hilo and USGS Pacific Islands Ecosystems Research Center; mgorresen@usgs.gov; (808) 985-6407
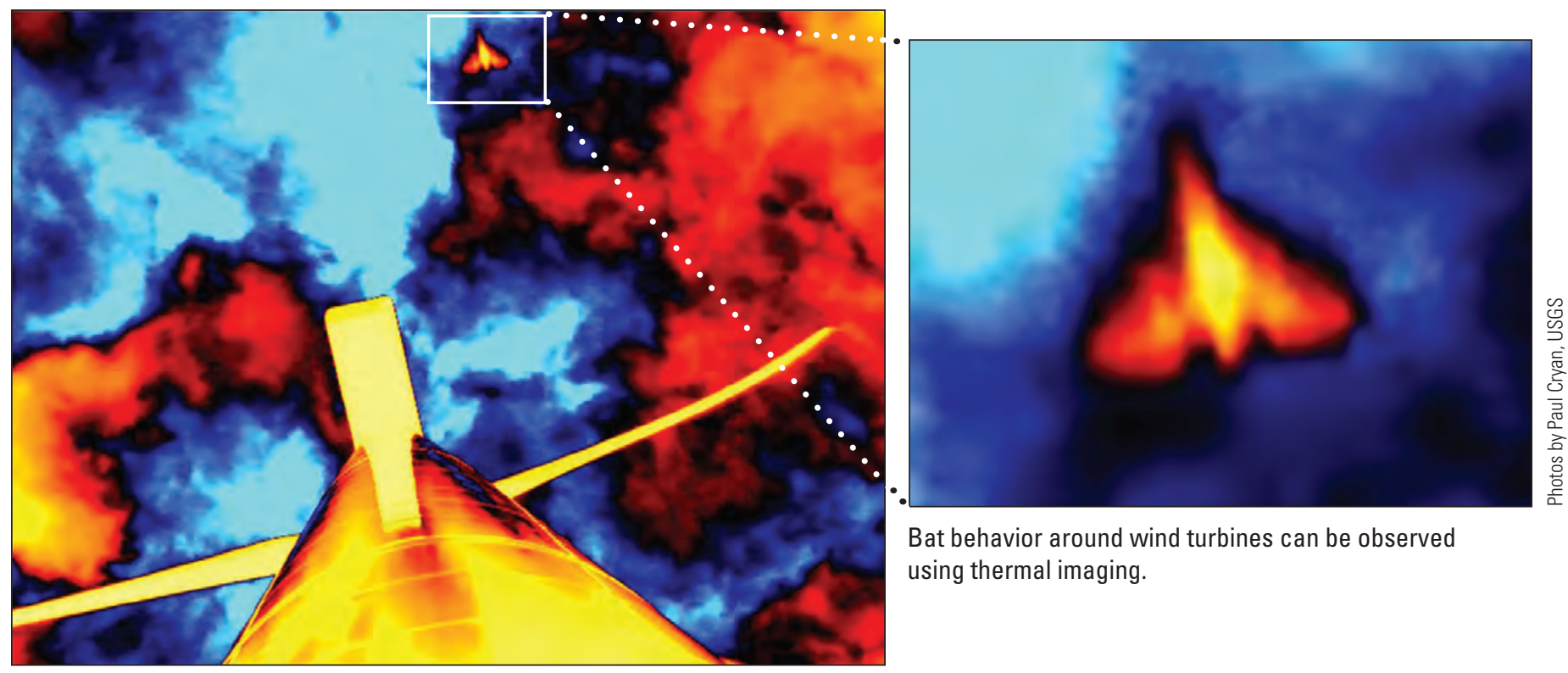

Bat behavior around wind turbines can be observed using thermal imaging. 
Publications

Gorresen, P.M., Cryan, P.M., Dalton, D.C., Wolf, Sandy, and Bonaccorso, F.J., 2015, Ultraviolet vision may be widespread in bats: Acta Chiropterologica, v. 17, no. 1, p. 193-198, http://dx.doi.org/10.3161/15081109acc2015.17.1.017.

Gorresen, P.M., Cryan, P.M., Dalton, D.C., Wolf, Sandy, Johnson, J.A., Todd, C.M., and Bonaccorso, F.J., 2015, Dim ultraviolet light as a means of deterring activity by the hoary bat Lasiurus cinereus semotus: Endangered Species Research, v. 28, no. 3, p. 249-257, http://dx.doi.org/10.3354/esr00694.

\section{Curtailment Strategies to Reduce Bat Fatalities}

Wildlife fatalities due to collisions with wind turbines have sparked efforts to reduce the number of fatalities through operational management. Recent studies have shown that altering turbine operations when winds are below certain speeds can decrease the number of bat fatalities, but questions remain regarding optimal management. The USGS and colleagues are modeling the proportion of bat fatalities occurring under varying meteorological conditions at Iberdrola Renewables Blue Creek Wind Farm in Ohio to identify conditions under which both bat fatalities and energy production loss can be minimized. Scientists are also investigating whether accurate and precise estimates of fatalities can be derived from carcass searches conducted at easily accessed areas, such as roads and pads beneath turbines.

Contact

Manuela Huso, USGS Forest and Rangeland Ecosystem Science Center; mhuso@usgs.gov; (541) 750-0948

\section{Comparing the Effectiveness of Ultrasonic Acoustic Deterrents to Operational Curtailment in Reducing Bat Fatalities}

Independent studies have shown that both operational curtailment and ultrasonic acoustic deterrents can be effective in reducing bat fatalities at wind energy facilities. A primary goal of this USGS and Bat Conservation International study is to directly compare the costs and benefits of the acoustic deterrents to operational curtailment. Fatality rates, when both curtailment and acoustic deterrents are applied singly and in combination, will be compared with fatality rates at untreated turbines to determine if one of these methods is more effective, if they are equally effective, or if they might act synergistically when employed simultaneously.

Contact

Manuela Huso, USGS Forest and Rangeland Ecosystem Science Center; mhuso@usgs.gov; (541) 750-0948

\section{Optimizing Acoustic Detection of Bats to Monitor Flight Activity Near Wind Turbines}

Monitoring bat activity at wind turbines often involves acoustic detectors placed outside of the rotor-swept zone. This spatial mismatch between the sampling location and the actual turbine sweep limits the models of the relationship between activity and fatality. USGS and Bat Conservation International scientists are collecting information about nightly bat activity measured by acoustic monitors located on turbine nacelles in the center of the rotor-swept zone. Scientists are combining this information with measurements of bat activity using near-infrared cameras centered on the nacelle and with estimates of bat fatality. If a direct, predictive relationship can be shown between fatality and activity, it may be useful in making pre-construction siting decisions and could suggest techniques to reduce fatalities post-construction.

Contact

Manuela Huso, USGS Forest and Rangeland Ecosystem Science Center; mhuso@usgs.gov; (541) 750-0948

\section{Publication}

Cryan, P.M., Gorresen, P.M., Hein, C.D., Schirmacher, M.R., Diehl, R.H., Huso, M.M., Hayman, D.T.S., Fricker, P.D., Bonaccorso, F.J., Johnson, D.H., Heist, Kevin, and Dalton, D.C., 2014, Behaviors of bats at wind turbines: Proceedings of the National Academy of Sciences, v. 111, no. 42, p. 15126-15131, http://dx.doi.org/10.1073/pnas.1406672111. 


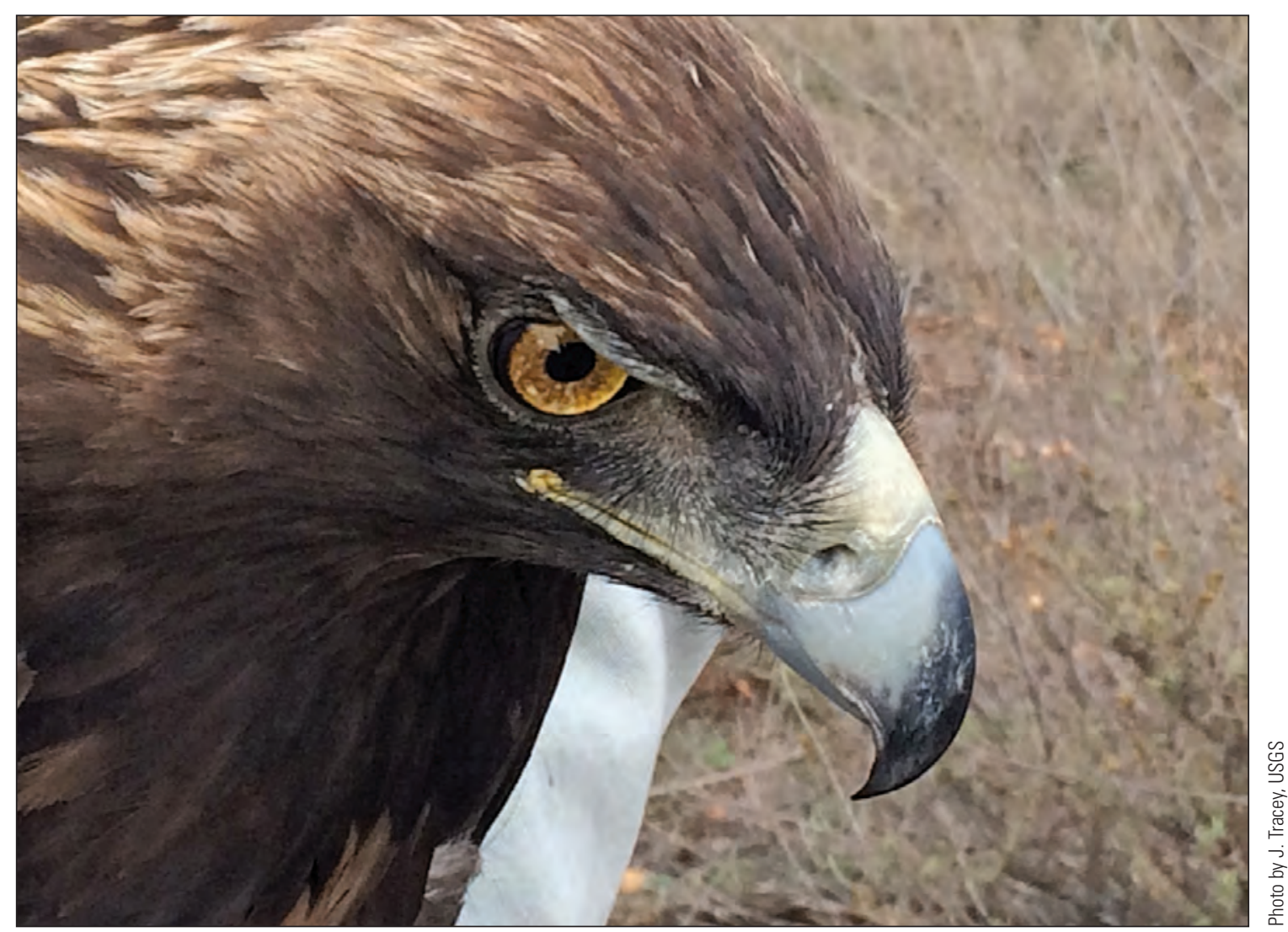

Golden eagle.

\section{Golden and Bald Eagles}

\section{Understand Risks}

\section{Golden Eagle Migration and Habitat Use}

The USGS is collecting information related to habitat use, home range, and population dynamics of golden eagles (Aquila chrysaetos) in the Central Appalachians, northeastern California, and the Mojave and Sonoran Deserts, using various methodologies including global positioning system-global system for mobile (GPS-GSM) communications telemetry, standard geographic information system (GIS) analyses, nest visits, and non-invasive genetic monitoring. The data collected have been used to model movement and to create risk models to assist resource management agencies in evaluating management options for this species. Results can inform resource managers about where and when eagles would be most at risk from disturbances associated with renewable energy structures. Data are being combined with datasets from other similar projects to create a framework and baseline to build an effective long-term golden eagle monitoring program in support of adaptive management.

\section{Contact}

Todd Katzner, USGS Forest and Rangeland Ecosystem Science Center; tkatzner@usgs.gov; (208) 426-5232

\section{Publications}

Braham, Melissa, Miller, Tricia, Duerr, A.E., Lanzone, Michael, Fesnock, Amy, LaPre, Larry, Driscoll, Daniel, and Katzner, Todd, 2015, Home in the heat-Dramatic seasonal variation in home range of desert golden eagles informs management for renewable energy development: Biological Conservation, v. 186, p. 225-232, http://dx.doi.org/10.1016/j.biocon.2015.03.020.

Dennhardt, A.J., Duerr, A.E., Brandes, David, and Katzner, T.E., 2015, Integrating citizen-science data with movement models to estimate the size of a migratory golden eagle population: Biological Conservation, v. 184, p. 68-78, http://dx.doi.org/10.1016/j.biocon.2015.01.003.

Dennhardt, A.J., Duerr, A.E., Brandes, David, and Katzner, T.E., 2015, Modeling autumn migration of a rare soaring raptor identifies new movement corridors in central Appalachia: Ecological Modeling, v. 303, p. 19-29, http://dx.doi.org/10.1016/j.ecolmodel.2015.02.010.

Duerr, A.E., Miller, T.A., Lanzone, Michael, Brandes, David, Cooper, Jeff, O’Malley, Kieran, Maisonneuve, Charles, Tremblay, J.A., and Katzner, Todd, 2014, Flight response of slope-soaring birds to seasonal variation in thermal generation: Functional Ecology, v. 29, no. 6, p. 779-790, http://dx.doi.org/10.1111/1365-2435.12381. 
Jachowski, D.S., Katzner, Todd, Rodrigue, J.L., and Ford W.M., 2015, Monitoring landscape-level distribution and migration phenology of raptors using a volunteer camera-trap network: Wildlife Society Bulletin, v. 39, no. 3, p. 553-563, http://dx.doi.org/10.1002/wsb.571.

Katzner, T.E., Turk, P.J., Duerr, A.E., Miller, T.A., Lanzone, M.J., Cooper, J.L., Brandes, David, Tremblay, J.A., and Lemaître, Jérôme, 2015, Use of multiple modes of flight subsidy by a soaring terrestrial bird, the golden eagle Aquila chrysaetos, when on migration: Journal of the Royal Society Interface, v. 12, no. 112, [publisher item identifier no.] 20150530, http://dx.doi.org/10.1098/rsif.2015.0530.

Mallon, J.M., Bildstein, K.L., and Katzner, T.E., 2016, In-flight turbulence benefits soaring birds: The Auk, v. 133, no. 1, p. 79-85, http://dx.doi.org/10.1642/auk-15-114.1.

Miller, T.A., Brooks, R.P., Lanzone, M.J., Brandes, David, Cooper, Jeff, Tremblay, J.A., Wilhelm, Jay, Duerr, Adam, Katzner, T.E., and Kelly, Jeff, eds., 2015, Limitations and mechanisms influencing the migratory performance of soaring birds: Ibis, v. 158, no. 1, p. 116-134, http://dx.doi.org/10.1111/ibi.12331.

Morneau, François, Tremblay, J.A., Todd, Charles, Chubbs, T.E., Maisonneuve, Charles, Lemaître, Jérôme, and Katzner, Todd, 2015, Known breeding distribution and abundance of golden eagles in eastern North America: Northeastern Naturalist, v. 22, no. 2, p. 236-247, http://dx.doi.org/10.1656/045.022.0201.

Poessel, S.A., Bloom, P.H., Braham, M.A., and Katzner, T.E., 2016, Age- and season-specific variation in local and long-distance movement behavior of golden eagles: European Journal of Wildlife Research, v. 62, no. 4, p. 377-393, http://dx.doi.org/10.1007/s10344-016-1010-4.

\section{Golden Eagle Movement and Conservation in San Diego County}

Using a combination of population surveys, biotelemetry methods, and genetic sampling, the USGS and collaborators are examining the relationships between human use and territory occupancy, nesting success, and movements of golden eagles in western San Diego County, California, and northern Baja California, Mexico. Researchers are also exploring the genetic distinctiveness of this population of golden eagles relative to other golden eagle populations in western North America. A multiyear golden eagle survey and tracking program began in 2014, and this year a USGS Data Series was released that presents biotelemetry data associated with 26 golden eagles tracked through February 2016. The report contains maps showing location data for each eagle. Results of the tracking program will provide local managers with information about the location and status of nesting and foraging areas for golden eagles, and the data can be used to inform decisions regarding potential disturbance and other

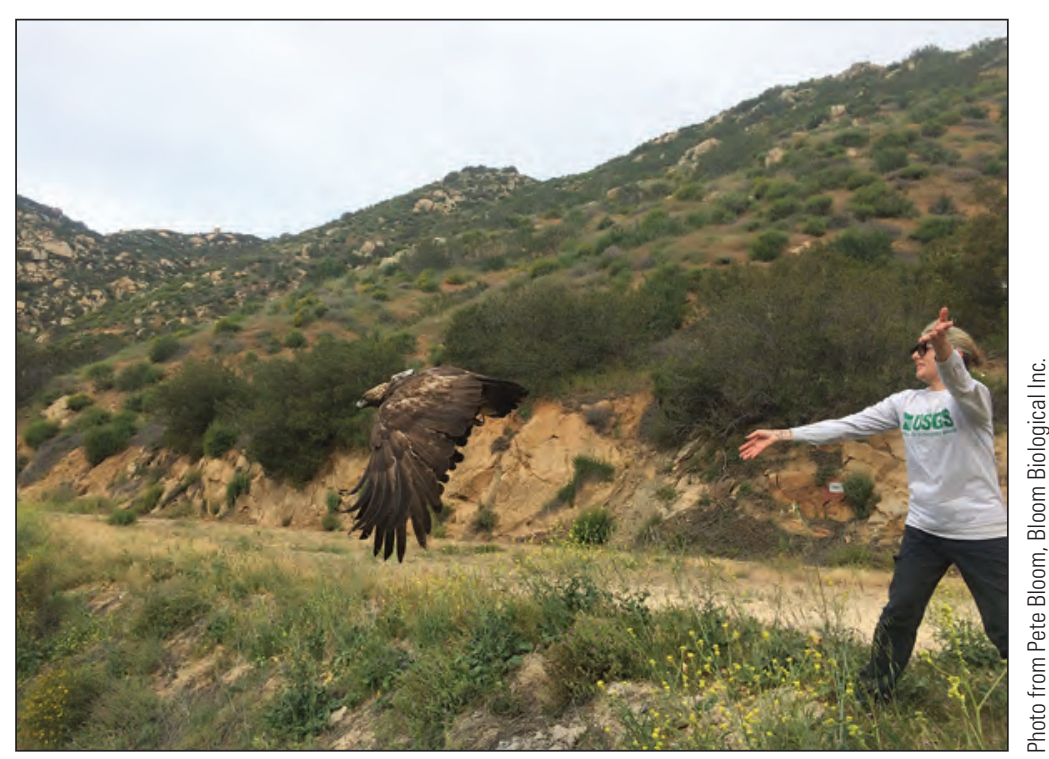

A USGS scientist releases a golden eagle with a solar-powered GPS transmitter, San Diego County, Calif.

adverse impacts. By standardizing sampling designs and monitoring protocols with other ongoing studies of golden eagles in California, this research will contribute to a broader understanding of the population status, demography, resource use, and genetic structure of golden eagles across a wide gradient of environmental conditions.

\section{Contacts}

Robert Fisher, USGS Western Ecological Research Center; rfisher@usgs.gov; (619) 225-6422

Jeff Tracey, USGS Western Ecological Research Center; jtracey@usgs.gov; (619) 225-6457

Melanie Madden, USGS Western Ecological Research Center; mmadden@usgs.gov; (619) 225-6450

David Wiens, USGS Forest and Rangeland Ecosystem Science Center; jwiens@usgs.gov; (541) 750-0961

Todd Katzner, USGS Forest and Rangeland Ecosystem Science Center; tkatzner@usgs.gov; (208) 426-5232

\section{Publication}

Tracey, J.A., Madden, M.C., Sebes, J.B., Bloom, P.H., Katzner, T.E., and Fisher, R.N., 2016, Biotelemetry data for golden eagles (Aquila chrysaetos) captured in coastal southern California, November 2014-February 2016: U.S. Geological Survey Data Series 994,32 p., http://dx.doi.org/10.3133/ds994. 


\section{Golden Eagles in New Mexico}

The BLM manages large areas in New Mexico that have a high potential for wind energy development. The USGS is conducting research to assess the risk that proposed wind energy developments in southeastern and south-central New Mexico may have on resident and migratory golden eagles. The study will assess habitat and space use of migratory and resident golden eagles; identify nest sites; estimate productivity and survival, origin, and migration patterns; and determine factors affecting golden eagle distribution. Results of the study may be used to inform the development of mitigation strategies that can reduce potential negative effects from proposed wind energy developments.

Contact

James Cain, USGS New Mexico Cooperative Fish and Wildlife Research Unit; jwcain@usgs.gov; (575) 646-3382

\section{Tracking Bald Eagles Near Wind Energy Facilities in the Central Great Plains}

The Central Great Plains is an important focus area for the development of new wind facilities. The USGS is leading an effort to track bald eagles (Haliaeetus leucocephalus) using GPS-GSM telemetry to acquire information that will help wildlife managers address potential conflict between bald eagles and wind turbines in parts of Oklahoma, Iowa, and Illinois. Researchers are collecting information on topography, weather, and land cover to understand how environmental conditions may put eagles at risk from collisions with turbines.

Contact

Todd Katzner, USGS Forest and Rangeland Ecosystem Science Center; tkatzner@usgs.gov; (208) 426-5232

\section{Assessing Eagle Use Frequency at Wind Energy Facilities}

Operation of wind energy facilities can adversely affect eagles, among other wildlife. USFWS guidelines suggest wind facility operators or developers survey eagle use and calculate the risk to eagles across the project area; however, questions have arisen concerning the degree to which data from survey plots represent eagle use over an entire project area. The USGS is using existing telemetry data on golden eagles in the Mojave Desert, California, to help the USFWS compare eagle use within a plot to eagle use over an entire project area. Results will add to understanding of golden eagle activity and provide a context for interpreting survey data collected at potential wind energy facilities.

Contact

Todd Katzner, USGS Forest and Rangeland Ecosystem Science Center; tkatzner@usgs.gov; (208) 426-5232

\section{Linking Habitat and Prey Availability to Golden Eagle Ecology in the Mojave Desert}

The USGS is assessing food habits, reproductive success, and prey availability of nesting golden eagles in the Mojave Desert. The results will be used to construct predictive models of prey availability that can then be used to link prey availability and abundance to eagle productivity and survival across the Desert Southwest. Information from this project can inform managers in California and Nevada in the design of conservation strategies as part of the Desert Renewable Energy Conservation Plan and in solar energy zones by providing information on potential loss of important foraging habitat for golden eagles.

\section{Contacts}

Kathleen Longshore, USGS Western Ecological Research Center; longshore@usgs.gov; (702) 564-4505

Todd Esque, USGS Western Ecological Research Center; tesque@usgs.gov; (702) 564-4506

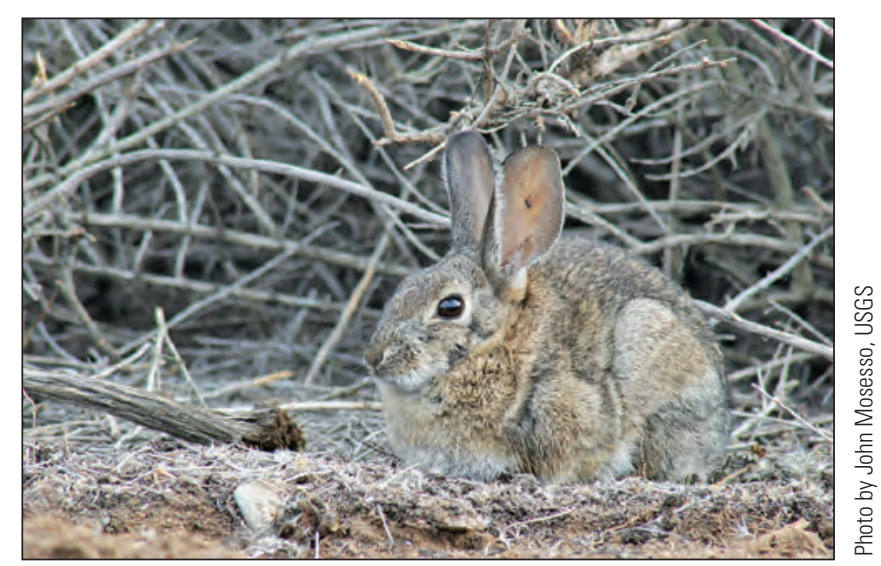

Desert cottontail in California.

\section{Publications}

Simes, M., Johnson, D., Streit, J., Longshore, K., Nussear, K., and Esque, T., in press, Common raven (Corvus corax) Kleptoparasitism at golden eagle (Aquila chrysaetos) nest in southern Nevada: The Wilson Journal of Ornithology.

Mojave Golden Eagle video: U.S. Geological Survey, 2016, Mojave golden eagles [Stephen M. Wessells, producer; Justin Louis, narrator]: U.S. Geological Survey video, 5:13 min., https://www.youtube.com/watch?v=6s--e_utRMDY. 


\section{Ecology of Leporids in the Western United States and Their Significance to Golden Eagles}

Several species of Leporids (rabbits, that is, Lepus spp. and Sylvilagus spp.) are well-documented as prey for golden eagles, and eagle demographics are linked to the abundance of rabbit populations. Yet there is no comprehensive analysis of rabbit ecology for the Western United States. Scientists at the USGS, USFWS, and the University of Nevada at Reno conducted a review and synthesis of population status, demographic patterns, general ecology, and the ecological significance of certain rabbit species to golden eagles across the Western United States. This information is fundamental to understanding the direct and indirect impacts of renewable energy development on eagle ecology. The results of this work can be incorporated into monitoring plans for golden eagles and their habitats and will be used as inputs to ecological models of eagle populations as the work advances.

\section{Contacts}

Todd Esque, USGS Western Ecological Research Center; tesque@usgs.gov; (702) 564-4506

Kathleen Longshore, USGS Western Ecological Research Center; longshore@usgs.gov; (702) 564-4505

\section{Publication}

Simes, M.T., Longshore, K.M., Nussear, K.E., Beatty, G.L., Brown, D.E., and Esque, T.C., 2015, Black-tailed and white-tailed jackrabbits in the American West-History, ecology, ecological significance, and survey methods: Western North American Naturalist, v. 75, no. 4, p. 491-519, http://dx.doi.org/10.3398/064.075.0406.

\section{Wintering Distribution of Golden Eagles in the Southern Great Plains}

The Southern Great Plains, which comprises eastern New Mexico and the panhandles of Oklahoma and Texas, is experiencing rapid wind energy development. The region has traditionally been an important wintering area for golden eagles. The USGS is assessing the distribution and abundance of wintering golden eagles in relation to land-cover and land-use types across this region. The results of this study will provide industry managers with insight into whether landscape features pose potential conflicts between wind energy development and eagles.

Contact

Clint Boal, USGS Texas Cooperative Fish and Wildlife Research Unit; cboal@usgs.gov; (806) 834-6536

\section{Eagle Surveys, Monitoring, and Distribution}

The USGS is reviewing the utility of the recommended golden eagle survey methodology given in the 2013 USFWS Eagle Conservation Plan Guidance (https://www.fws.gov/migratorybirds/pdf/management/eagleconservationplanguidance.pdf) with a goal of assessing the influence of different survey time intervals, sampling periods, and landscapes on detectability and occupancy estimates of golden eagles. Repeat 800-meter radius, 1-hour point count surveys were conducted during two sampling periods at 50 sample points in three areas over two consecutive breeding seasons. A total of 1,500 hours of survey data are being evaluated to determine the level of survey effort necessary to adequately evaluate eagle occurrence depending on area, season, and year. Subsequent simulation of detection probabilities and survey effort will help inform the temporal and spatial effort necessary to improve the efficacy of point count surveys in evaluating golden eagle occurrence.

Contact

Clint Boal, USGS Texas Cooperative Fish and Wildlife Research Unit; cboal@usgs.gov; (806) 834-6536

\section{Measure Impacts}

\section{Golden Eagle Monitoring Protocol for the Desert Renewable Energy Conservation Plan}

The Desert Renewable Energy Conservation Plan (DRECP) was developed to provide protection of Mojave and Colorado Desert ecosystems, while allowing for the appropriate development of renewable energy projects. Effective surveys for golden eagles and monitoring of their status are needed to assess the effects of energy development. The USGS is developing survey sample designs and field procedures to determine the distribution and demography of golden eagles in the DRECP area. The protocol will be designed to provide information required to promote golden eagle conservation and compatible renewable energy development. Information collected will be especially critical in determining whether regulatory requirements and goals of the conservation plan are being met.

Contact

David Wiens, USGS Forest and Rangeland Ecosystem Science Center; jwiens@usgs.gov; (541) 750-0961 


\section{Golden Eagles Around the Altamont Pass Wind Resource Area, California}

The Altamont Pass Wind Resource Area in California is estimated to have been responsible for the fatalities of more than 1,000 golden eagles since becoming fully operational. This study aims to determine whether the breeding population of golden eagles in the surrounding area has the resiliency to absorb estimated levels of wind turbine blade-strike fatalities over time. The USGS and partners are using historical and current eagle data to assess territory occupancy, abundance, breeding success, survival, and habitat use of different age classes of golden eagles. This information is being used to develop a predictive model of how the local population of golden eagles might respond to estimated fatalities. Additionally, results from this study provide data on spatial patterns of density and reproductive success of golden eagles during a period of extreme drought in central California, which can help managers identify and prioritize important areas for conservation.

\section{Contacts}

David Wiens, USGS Forest and Rangeland Ecosystem Science Center; jwiens@usgs.gov; (541) 750-0961

Todd Katzner, USGS Forest and Rangeland Ecosystem Science Center; tkatzner@usgs.gov; (208) 426-5232

\section{Publications}

Katzner, T.E., Nelson, D.M., Braham, M.A., Doyle, J.M., Fernandez, N.B., Duerr, A.E., Bloom, P.H., Fitzpatrick, M.C., Miller, T.A., Culver, R.C.E., Braswell, Loan, and DeWoody, J.A., in press, Golden eagle fatalities demonstrate the continental-scale consequences of local-scale renewable energy generation: Conservation Biology.

Wiens, J.D., Kolar, P.S., Fuller, M.R., Hunt, W.G., and Hunt, Teresa, 2015, Estimation of occupancy, breeding success, and abundance of golden eagles (Aquila chrysaetos) in the Diablo Range, California, 2014: USGS Open-File Report 2015-1039, 23 p., http://dx.doi.org/ 10.3133/ofr20151039.

\section{Using Drones to Detect Golden Eagle Carcasses}

The USGS, in collaboration with Oregon State University and the Confederated Tribes of Warm Springs, is investigating the use of unmanned aircraft systems, or drones, to detect golden eagle carcasses at wind energy facilities. The objectives of the investigation are to use change-detection software to compare ground images taken by drones on separate flights over time to detect the timing of carcass appearance and to evaluate whether detection is affected by vegetation or carcass size.

Contact

Manuela Huso, USGS Forest and Rangeland Ecosystem Science Center; mhuso@usgs.gov; (541) 750-0948
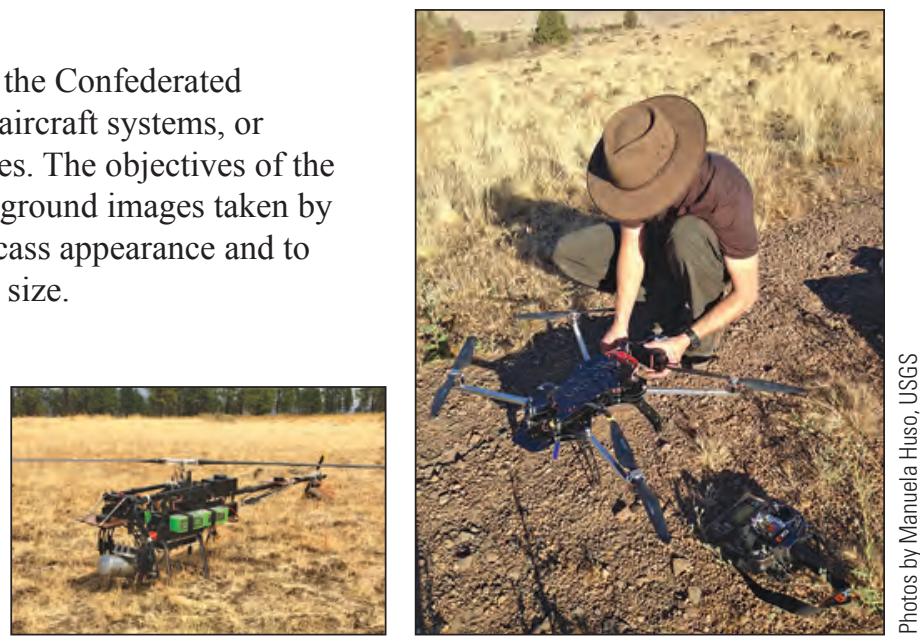

Testing drones as a tool for detecting eagle carcasses.

\section{Inform Solutions}

\section{Predicting Golden Eagle Fatalities at Wind Facilities}

The USGS, working with the USFWS, has developed a predictive model of golden eagle "take" at a given wind facility. The model is based on preconstruction eagle-use surveys and design considerations. The USFWS uses the model to work with facility applicants at the design and permitting stages. This model serves as the basis for compensatory mitigation, which may be needed. Researchers also are helping develop eagle population models at the regional level to evaluate the effect of the cumulative take on population dynamics. Both efforts explicitly acknowledge uncertainty and, by doing so, permit risk analysis and the implementation of adaptive management.

Contact

Michael Runge, USGS Patuxent Wildlife Research Center; mrunge@usgs.gov; (301) 497-5748

\section{Publication}

New, Leslie, Bjerre, Emily, Millsap, Brian, Otto, M.C., and Runge, M.C., 2015, A collision risk model to predict avian fatalities at wind facilities-An example using golden eagles, Aquila chrysaetos: PLOS ONE, v. 10, no.7, e0130978, http://dx.doi.org/10.1371/ journal.pone.0130978. 


\section{Golden Eagle Late-Summer Occupancy in Wyoming}

The USGS is developing golden eagle habitat-occupancy models to overlay with maps of potential energy development, including wind energy in Wyoming and other parts of the Western United States. Models and maps will highlight biological strengths and weaknesses, or high and low quality habitat, across the landscape. Map overlays explicitly delineate opportunities for conservation - areas of high quality habitat where the energy-generating potential is low — and imminent threats - areas of high quality habitat where the energy-generating potential is high. These tools can assist resource managers in their efforts with industry concerning siting for energy development and the identification of areas for off-site mitigation.

\section{Contact}

Zachary Bowen, USGS Fort Collins Science Center; bowenz@usgs.gov; (970) 226-9218

\section{Publication}

Tack, J.D., and Fedy, B.C., 2015, Landscapes for energy and wildlife - Conservation prioritization for golden eagles across large spatial scales: PLOS ONE, v. 10, no. 8, e0134781, http://dx.doi.org/10.1371/journal.pone.0134781.

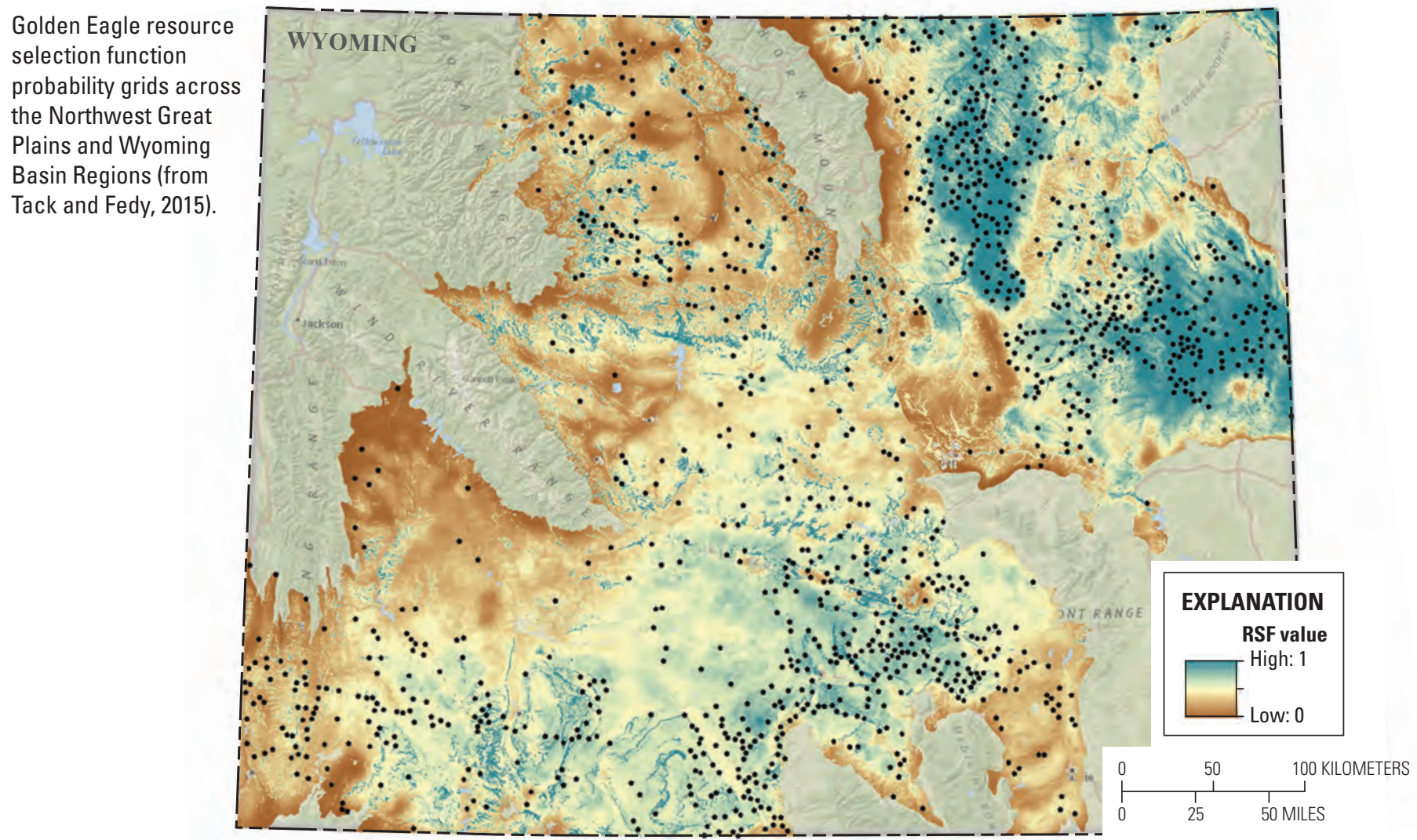

\section{Habitat Prioritization for Raptors in Wyoming}

The USGS is leading a project to develop predictive models of the relationship between the available habitat of raptors, such as golden eagle (Aquila chrysaetos), ferruginous hawk (Buteo regalis), northern harrier (Circus cyaneus), and prairie falcon (Falco mexicanus), and their habitat use in Wyoming. This project will create models and maps that can be used to identify priority habitat areas and assist resource managers with raptor conservation by providing information that can be used in the siting of wind power infrastructure and prioritization of locations for strategic and focused conservation efforts.

Contact

Zachary Bowen, USGS Fort Collins Science Center; bowenz@usgs.gov; (970) 226-9218

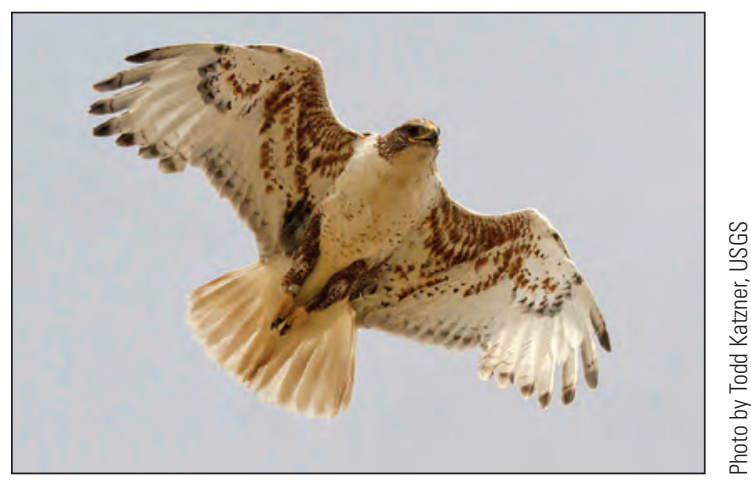

Ferruginous hawk in flight. 


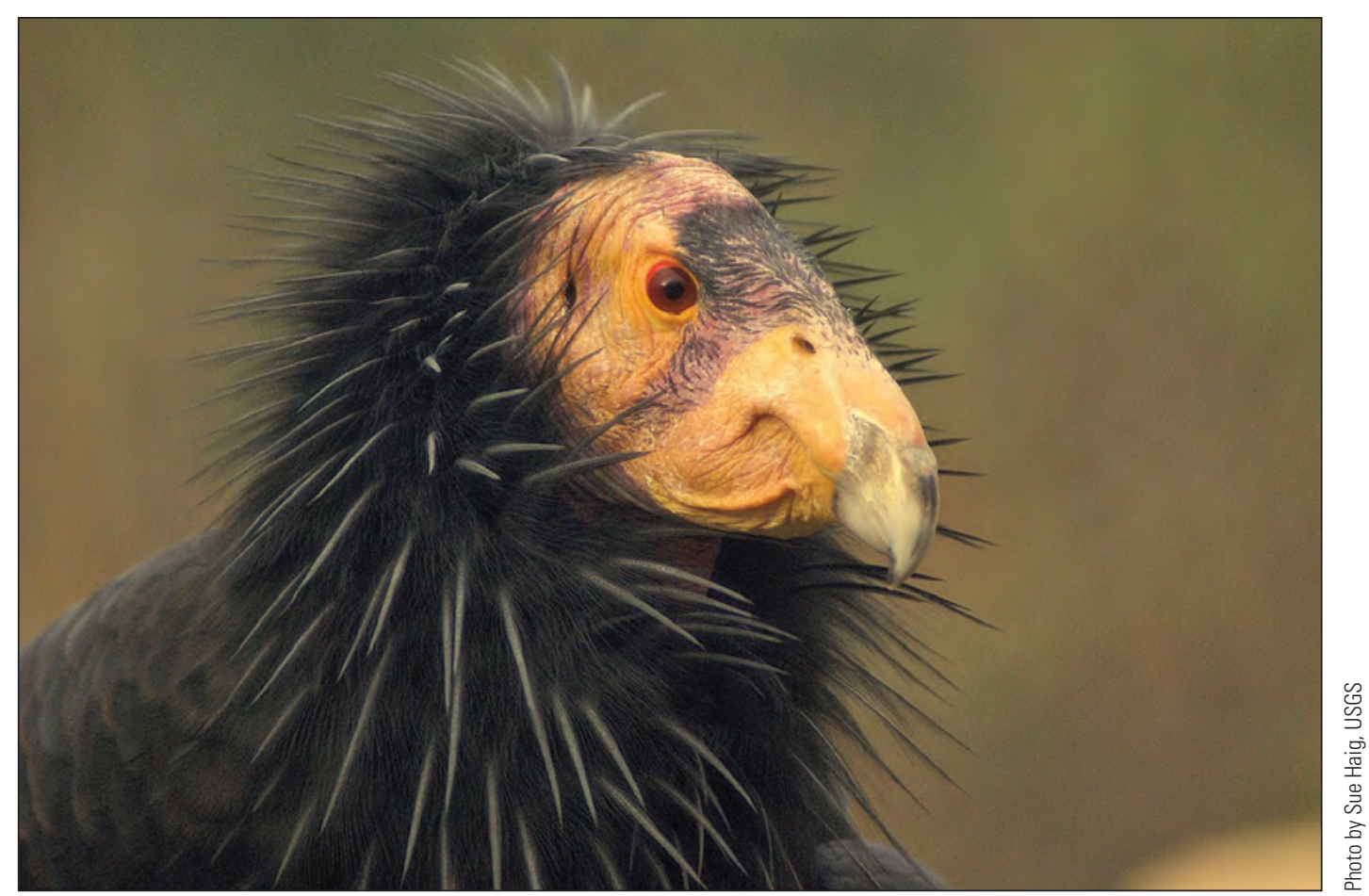

California condor at the Portland Zoo.

\section{Condors and Other Raptors}

\section{Raptor Density and Distributions in Southern California Deserts}

The USGS and colleagues determined predatory bird distribution in areas designated for protection under the DRECP and how this distribution is affected by existing development. Researchers used a unique approach to compare current bird count data to counts from approximately 20 years ago. Results indicated that human development and activity in the Mojave Desert have likely increased numbers of red-tailed hawks (Buteo jamaicensis), American kestrels (Falco sparverius), and loggerhead shrikes (Lanius ludovicianus), yet populations of prairie falcons (Falco mexicanus) and golden eagles (Aquila chrysaetos) seem to have declined. The species that have increased in number show associations with human activity in contrast to the species that have declined in number. The results of this comparison provide baseline data on raptor abundance and density in the DRECP for future comparisons.

\section{Contact}

Todd Katzner, USGS Forest and Rangeland Ecosystem Science Center; tkatzner@usgs.gov; (208) 426-5232

\section{Publication}

Duerr, A.E., Miller, T.A., Cornell-Duerr, K.L., Lanzone, M.J., Fesnock, Amy, and Katzner, T.E., 2015, Landscape-scale distribution and density of raptor populations wintering in anthropogenic-dominated desert landscapes: Biodiversity and Conservation, v. 24, no. 10, p. 2365-2381, http://dx.doi.org/10.1007/s10531-015-0916-6.

\section{Using GPS-GSM Telemetry to Study Condor Flight}

Condor populations recovering in California face numerous threats, including the development of wind energy facilities. To understand how condor flight behavior may expose them to risk from wind energy, scientists from the USGS, USFWS, California Department of Fish and Wildlife, and BLM are initiating a new study to track condor flight using high-frequency GPS-GSM telemetry systems. Researchers will record movements of California condors (Gymnogyps californianus) to understand how their flight behavior, especially flight altitude, responds to variation in topography and weather. This information can be used to identify wind and topographic variables that may be preferentially used by condors and to predict risk to birds from existing and proposed turbines.

\section{Contact}

Todd Katzner, USGS Forest and Rangeland Ecosystem Science Center; tkatzner@usgs.gov; (208) 426-5232 


\section{California Condor Movement Behavior and Habitat Use}

The USGS and the San Diego Zoo's Institute for Conservation Research are using GPS telemetry to collaborate on a project to model the three-dimensional home range of California condors. The primary goal of the project is to study the movement behavior and habitat use of California condors released in Baja, Mexico. This information can be used to improve the precision of space-use models of the California condor, improve assessments of condor space use and the potential intersection with three-dimensional objects, such as buildings, and help evaluate risks from encounters with wind facilities.

\section{Contact}

Jeff Tracey, USGS Western Ecological Research Center; jtracey@usgs.gov; (619) 225-6457

\section{Publications}

Tracey, J.A., Sheppard, J.K., Lockwood, G.K., Chourasia, Amit, Tatineni, Mahidhar, Fisher, R.N., Sinkovits, R.S., 2014, Efficient 3D movement-based kernel density estimator and application to wildlife ecology, in Proceedings of the XSEDE14 ConferenceEngaging Communities-July 13-18, 2014, Marriott Marquis, Atlanta, Georgia: XSEDE '14 Annual Conference of the Extreme Science and Engineering Discovery Environment, 3rd, Atlanta, Georgia, 2014, published by Association for Computing Machinery, New York, N.Y., article no. 14, unpaged, http://dx.doi.org/10.1145/2616498.2616522.

Tracey, J.A., Sheppard, James, Zhu, Jun, Wei, Fuwen, Swaisgood, R.R., Fisher, R.N., and Sueur, Cédric, eds., 2014, Movement-based estimation and visualization of space use in 3D for wildlife ecology and conservation: PLOS ONE, v. 9, no. 7, e101205, http://dx.doi.org/10.1371/journal.pone.0101205.

\section{A movement-based kernel density estimator and computer visualization showing $3 \mathrm{D}$ home range for a California condor. The contours in transparent white, yellow, orange, and red represent the $99 \%, 95 \%, 75 \%$, and $50 \%$ 3D movement-based kernel density estimator volumes, respectively (from Tracey and others, 2014).}

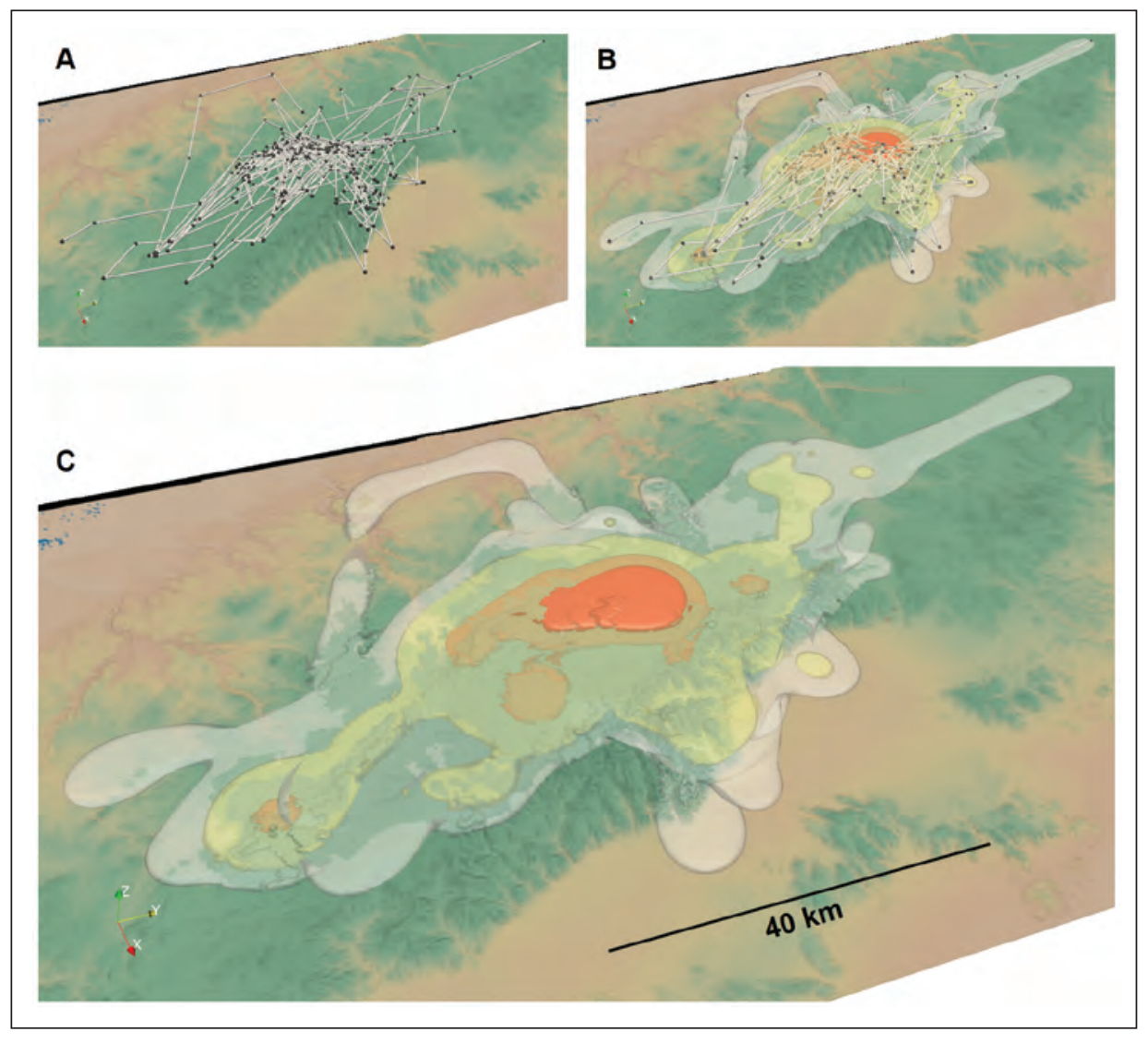

\section{California Condor Space Use and Wind Resources}

The USGS evaluated how wind resources in California affect patterns of condor use and movement through various habitats. Analyses and modeling addressed variation in condor home range, habitat selection, and relationships between condor occurrence and atmospheric properties, particularly thermal and wind, throughout the annual cycle. Researchers found that condor resource selection varied relative to habitat type: dune and rock habitats along coastal areas were preferred, whereas shrubland and evergreen forest habitats were used substantially less. Differential use of habitats was often linked to proximity of release site; however, meteorological conditions, such as thermal height, thermal velocity, and wind speed, were linked to condor use of ecological subregions. Habitat and meteorological conditions may interact in complex ways to influence condor resource selection across the landscape. 


\section{Contact}

Sue Haig, USGS Forest and Rangeland Ecosystem Science Center; susan_haig@usgs.gov; (541) 750-0981

Publications

Rivers, J.W., Johnson, J.M., Haig, S.M., Schwarz, C.J., Burnett, L.J., Brandt, Joseph, George, Daniel, and Grantham, Jesse, 2014, An analysis of monthly home range size in the critically endangered California Condor Gymnogyps californianus: Bird Conservation International, v. 24, no. 4, p. 492-504, http://dx.doi.org/10.1017/s0959270913000592.

Rivers, J.W., Johnson, J.M., Haig, S.M., Schwarz, C.J., Burnett, L.J., Brandt, Joseph, George, Daniel, and Grantham, Jesse, 2014, An analysis of monthly home range size in the critically endangered California Condor Gymnogyps californianus-CORRIGENDUM: Bird Conservation International, v. 25, no. 2, p. 258, http://dx.doi.org/10.1017/s0959270915000039.

\section{Potential Interactions of Migrating Raptors and Wind Energy Sites at the International Scale}

Swainson's hawks (Buteo swainsoni) are long-distance migratory raptors that breed across western North America and migrate to Argentina for the winter. This annual round trip of approximately 12,500 miles takes the hawks over 12 countries, which all have interests in wind energy development. The USGS is using GPS transmitters to determine precise migration routes, which are then overlaid on maps of wind energy potential. This provides the means to identify high-risk areas for migrating raptors at the international scale. Analysis of 3 years of data for adult hawks is underway, and field data collection is now being shifted to include young hawks.

Contact

Clint Boal, USGS Texas Cooperative Fish and Wildlife Research Unit; cboal@usgs.gov; (806) 742-2851

\section{Re-0ccupancy of Breeding Territories by Ferruginous Hawks in Wyoming}

A USGS-led study used design-based sampling and occupancy models to test relationships of environmental factors that influence raptor demographics with reoccupancy of breeding territories by ferruginous hawks across Wyoming in 2011-13. The study also tested correlations of territory reoccupancy with oil and gas infrastructure, a leading cause of habitat modification throughout the range of this species of conservation concern.

Contact

Katie Dugger, USGS Oregon Cooperative Fish and Wildlife Research Unit; katie.dugger@oregonstate.edu; (541) 737-2473

Publication

Wallace, J.P., Kennedy, P.L., Squires, J.R., Oakleaf, R.J., Olson, L.E., Dugger, K.M., and Jiang, Zhiang, eds., 2016, Re-occupancy of breeding territories by ferruginous hawks in Wyoming - Relationships to environmental and anthropogenic factors: PLOS ONE, v. 11, no. 4, e0152977 http://dx.doi.org/10.1371/journal.pone.0152977.

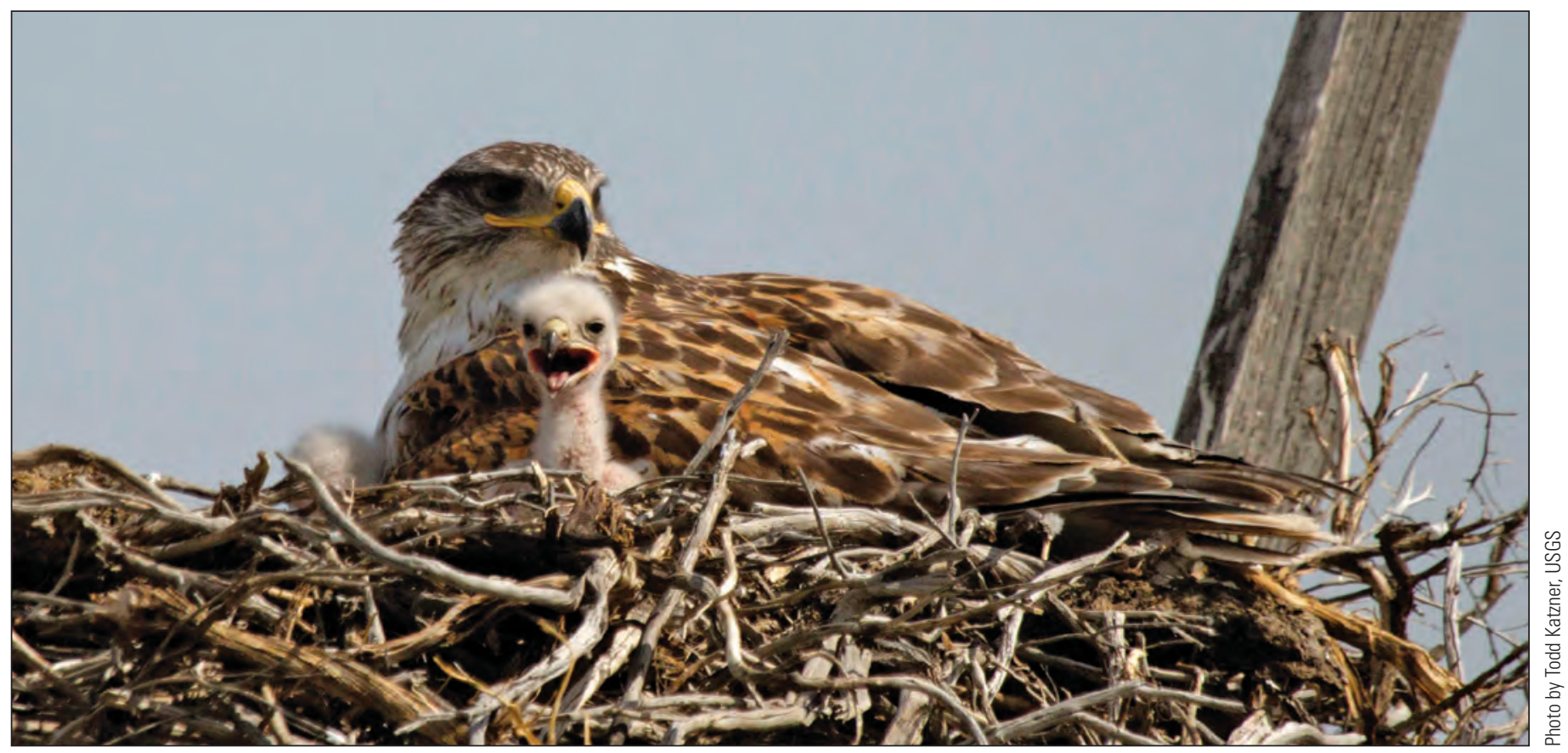

Ferruginous hawk with nestlings. 


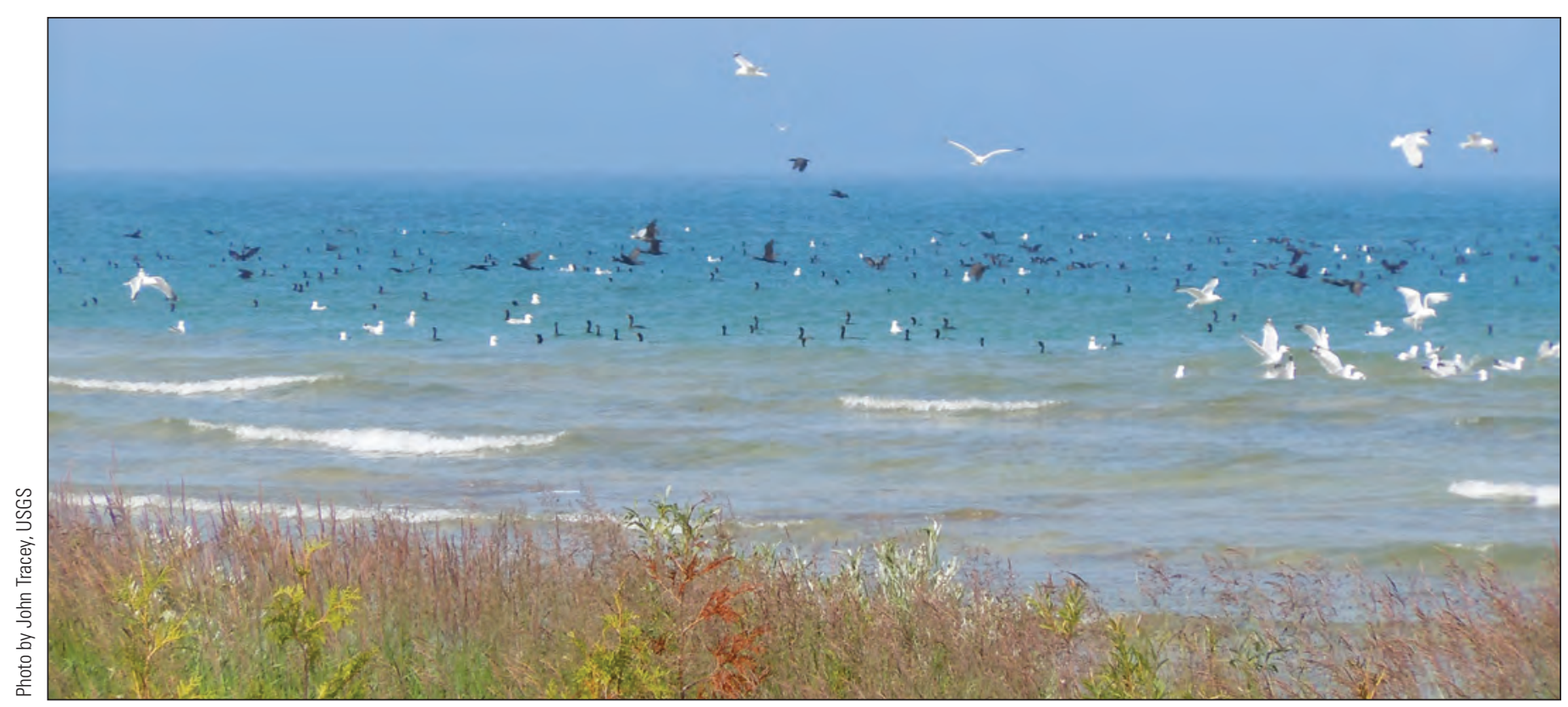

Birds on the shore of Lake Michigan.

\section{Great Lakes, Coastal, and Marine Birds}

\section{Understand Risks}

\section{Statistical Guidelines for Sampling of Marine Avian Populations}

Interest in development of offshore renewable energy facilities has led to a need for high-quality, statistically robust information on marine wildlife distributions. The USGS developed a practical approach to estimate the amount of sampling effort required to have sufficient statistical power to identify species-specific "hotspots" and "coldspots" of marine bird abundance and occurrence in an offshore environment divided into discrete spatial units, or lease blocks. Hotspots and coldspots are defined relative to a regional mean abundance and (or) occurrence probability for each species of interest. A method was also developed for testing the statistical significance of possible hotspots and coldspots. Both methods are illustrated with historical bird survey data from the Atlantic Seabird Compendium.

\section{Contact}

Allan O’Connell, USGS Patuxent Wildlife Research Center; aoconnell@usgs.gov; (301) 497-5525

\section{Publication}

Zipkin, E.F., Kinlan, B.P., Sussman, Allison, Rypkema, Diana, Wimer, Mark, and O’Connell, A.F., 2015, Statistical guidelines for assessing marine avian hotspots and coldspots - A case study on wind energy development in the U.S. Atlantic Ocean: Biological Conservation,

v. 191, November, p. 216-223, http://dx.doi.org/10.1016/j.biocon.2015.06.035.

\section{Possible Effects of Turbine Noise on Diving Birds}

Construction and maintenance of wind turbines can increase in-air and underwater noise levels from pile driving, shipping of materials, turbine operation, and other activities. USGS measured in-air auditory thresholds in diving bird species, using behavioral and electrophysiological (auditory brainstem response [ABR]) techniques. All 10 species tested shared a common region of the greatest sensitivity, from 1,000 to 3,000 hertz, although audiograms differed significantly across species. Thresholds of all duck species tested were more similar to each other than to the two non-duck species tested; however, ABR thresholds were higher than psychoacoustic thresholds at all frequencies. At present both of these methodologies are being tested on long-tailed ducks (Clangula hyemalis) and lesser scaup (Aythya affinis) in the underwater environment. These data will be the first evaluation of underwater hearing abilities of seabirds with the ultimate goal of evaluating the impacts of underwater noise activities on seabirds.

Contact

Alicia M. Berlin, USGS Patuxent Wildlife Research Center; aberlin@usgs.gov; (301) 497-5730 


\section{Publications}

Crowell, S.E., Wells-Berlin, A.M., Carr, C.E., Olsen, G.H., Therrien, R.E., Yannuzzi, S.E., and Ketten, D.R., 2015, A comparison of auditory brainstem responses across diving bird species: Journal of Comparative Physiology A, v. 201, no. 8, p. 803-815, http://dx.doi.org/10.1007/ s00359-015-1024-5.

Crowell, S.E., Wells-Berlin, A.M., Therrien, R.E., Yannuzzi, S.E., and Carr, C.E., 2016, In-air hearing of a diving duck-A comparison of psychoacoustic and auditory brainstem response thresholds: Journal of the Acoustical Society of America, v. 139, no. 5, p. 3001-3008, http://dx.doi.org/10.1121/1.4948574.

\section{The Great Lakes}

\section{Monitoring and Mapping Avian Resources in Nearshore and Open Waters of Lake Michigan}

USGS scientists have surveyed pelagic bird use in priority areas of Lake Michigan during fall and winter periods over a 4-year period to determine distribution patterns and abundance in nearshore and open water areas for the common loon (Gavia immer), red-throated loon (G. stellata), white-winged scoter (Melanitta deglandi), black scoter (M. nigra), surf scoter (M. perspicillata), long-tailed duck (Clangula hyemalis), common merganser (Mergus merganser), red-breasted merganser (M. serrator), red-necked grebe (Podiceps grisegena), horned grebe (P. auritus), greater scaup (Aythya marila), lesser scaup (A. affinis), and other waterbirds.

Contact

Kevin Kenow, USGS Upper Midwest Environmental Sciences Center; kkenow@usgs.gov; (608) 781-6278

\section{Documenting Movements, Habitat Use, and Foraging Patterns of Common Loons}

USGS scientists are employing both satellite telemetry and archival geolocator tags to document the movements, habitat use, and foraging patterns of common loons across the Great Lakes during migration relative to future wind energy development. Additional work is planned for fall 2016 to tag birds and determine local movement patterns of long-tailed ducks on Lake Michigan. Data on waterbird seasonal movement patterns and core use areas based on aerial surveys and telemetry will be used to inform an environmental impact assessment of potential wind turbine placement and to assist with identifying, evaluating, and recommending alternative wind facility sites in the Great Lakes.

Contact

Kevin Kenow, USGS Upper Midwest Environmental Sciences Center; kkenow@usgs.gov; (608) 781-6278

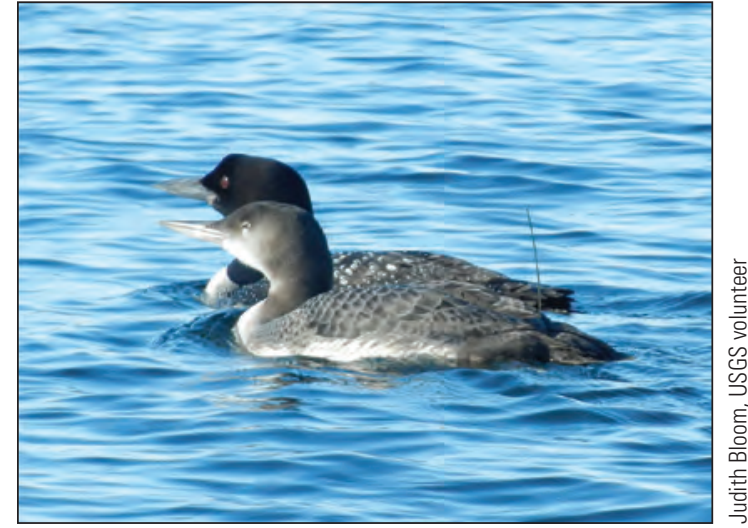

A juvenile common loon wearing a satellite transmitter antenna follows an adult at Tomahawk Lake, Wis.

\section{Airspace Use by Migrating Landbirds at Lake Erie}

Interest is growing to develop wind energy capacity along Great Lakes shorelines both onshore and offshore. With this growth comes the consideration of potential impacts to the large concentrations of landbirds that use the southern Lake Erie shoreline during spring and fall migration. The USGS is using two marine radars operated simultaneously at shoreline and inland sites at 3 or 15 miles. The data will be used to describe movement patterns of night-migrating landbirds, estimate ascent and descent flight profiles for night-migrating landbirds in relation to distance from the southwestern Lake Erie shoreline, and estimate intensity of nightly bird movements using radar and relate the results to data on banded birds.

Contact

Eileen Kirsch, USGS Upper Midwest Environmental Sciences Center; ekirsch@usgs.gov; (608) 781-6226 


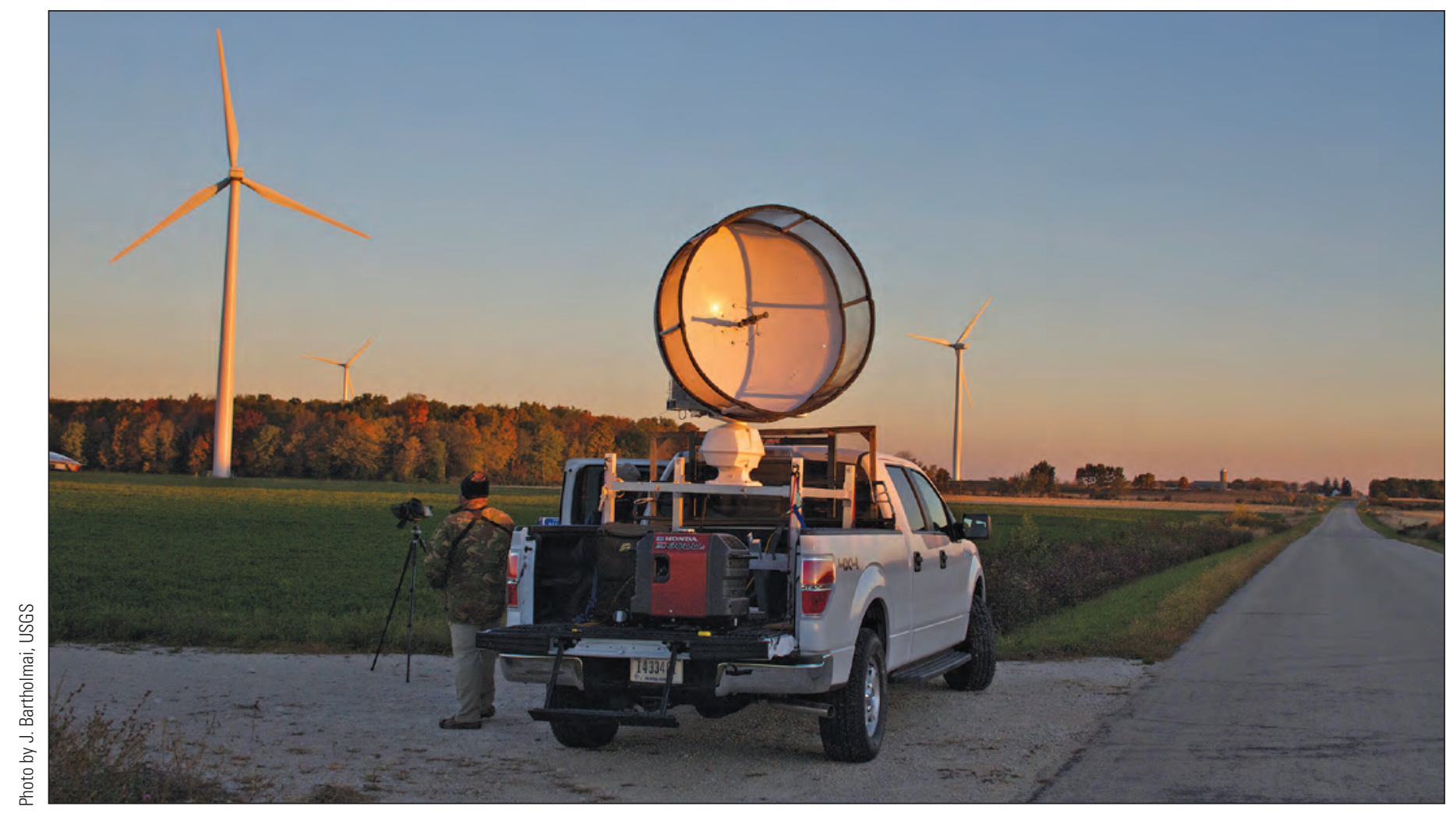

Portable radar is used to track bird flight near wind turbines.

\section{The Atlantic}

\section{Satellite Tracking Offshore Habitat Use in Diving Bird Species}

USGS scientists are using platform terminal transmitter satellite tracking tags to determine occurrence and local movement patterns of red-throated loons (Gavia stellata), surf scoters (Melanitta perspicillata), and northern gannets (Morus bassanus) in federal waters of the mid-Atlantic region of the United States during migration and winter. From 2012 to 2016 , scientists tracked the movements of 75 gannets and 66 loons, and from 2001 to 2016, scientists tracked 217 scoters on their northward migration to their breeding colonies and on their southward migration back to and through the mid-Atlantic region. Data are presently being analyzed and can inform siting, permitting, and regulation of future offshore wind development and provide important information on key habitat use and migration of a suite of species with different ecological niches.

\section{Contact}

Alicia M. Berlin, USGS Patuxent Wildlife Research Center; aberlin@usgs.gov; (301) 497-5730

\section{External GPS-GSM-Based Transmitters for Tracking Seabirds}

USGS researchers are testing solar-powered GPS-GSM-based transmitters on seabirds to provide data with the necessary precision to capture fine-scale movement patterns. This new information will allow them to better relate the influence of weather, resource availability, and hazardous conditions for seabirds and thus predict conflict with offshore wind power facilities along the Atlantic coast. Preliminary data have corroborated previous platform terminal transmitter tracking data from these species and are also providing preliminary altitudinal data. The deployment of additional transmitters will be instrumental in modeling habitat use, mortality risk, and the impact of weather on flight behavior for these species in the face of multiple proposed offshore wind facilities along the Atlantic coast.

\section{Contact}

Alicia M. Berlin, USGS Patuxent Wildlife Research Center; aberlin@usgs.gov; (301) 497-5730 


\section{The Atlantic Seabird Compendium}

To assess the impacts of alternative energy on marine bird populations, large amounts of occurrence information are required along with biophysical data that influence species distributions. Before a model is constructed, data need to be retrieved, reconfigured, synthesized, and vetted. USGS researchers have created a catalog of more than 100 datasets, developed computer programs to facilitate comparisons between historical and recent surveys, and standardized survey sampling efforts for the Atlantic Outer Continental Shelf. This database is the single largest repository of marine bird information available for the western Atlantic. It includes information dating back to the 1970s and more than 350,000 seabird occurrence records from Florida to Maine, and one from Atlantic Canada.

Contact

Mark Wimer, USGS Patuxent Wildlife Research Center; mwimer@usgs.gov; (301) 497-5596

\section{Publication}

O'Connell, Allan, Spiegel, C.S., and Johnson, Scott, 2011, Compendium of avian occurrence information for the continental shelf waters along the Atlantic Coast of the United States - Final Report (Database Section-Shorebirds): U.S. Geological Survey and Bureau of Ocean Energy Management, OCS Study, Hadley, Mass., BOEM 2012-076, 35 p., http://tethys.pnnl.gov/sites/default/files/publications/BOEM-2012-076.pdf.

\section{Modeling of Atlantic Coast Seabird Distributions}

The USGS used occurrence information from the Atlantic Seabird Compendium, focusing on the Atlantic Flyway Sea Duck Survey, Massachusetts Audubon surveys, Rhode Island offshore marine surveys, and deposition data collected by Seabird Ecological Assessment Network to develop hierarchical models for marine avian populations. These data can be used to assess the impacts of proposed energy developments and show the importance of seasonality, the North Atlantic Oscillation, sea surface temperature, chlorophyll, and other factors in estimating the distributions and relative abundance for a suite of species. Occupancy estimates will be used to assemble a seabird community model in Nantucket Sound and off the coast of Rhode Island.

Contact

Allan O’Connell, USGS Patuxent Wildlife Research Center; aoconnell@usgs.gov; (301) 497-5525

Publication

Flanders, N.P, Gardner, B., Winiarski, K.J., Paton, P.W.C., Allison, T., and O’Connell, A.F., 2015, Key seabird areas in southern New England identified using a community occupancy model: Marine Ecology Progress Series, v. 533, p. 277-290, http://dx.doi.org/10.3354/meps11316.

\section{Potential Impacts of Offshore Wind Energy Projects on Endangered Roseate Terns}

Offshore wind energy projects have been permitted for two coastal areas in Massachusetts and Rhode Island and have been proposed for offshore areas of New York. Fish-eating terns traveling through these offshore areas could be impacted by the construction and operation of wind turbines. The "Cape and Islands" area of southeastern Massachusetts is a particularly important area for the endangered northwest Atlantic roseate tern (Sterna dougallii) population because most roseate terns congregate in this area in large numbers for several months during the postbreeding staging period prior to fall migration. USGS researchers will examine long-term temporal variation in staging site use and estimate postfledging survival of hatch year roseate terns and age-specific "survival-and-return-north" of adults prior to the construction of offshore wind turbine operations. Data on temporal variation in the use and estimates of the length-of-stay at staging sites could be useful for evaluating the timing or risks to roseate terns from proposed offshore wind energy projects.

\section{Contact}

Jeffrey Spendelow, USGS Patuxent Wildlife Research Center; jspendelow@usgs.gov; (301) 497-5665

\section{Publication}

Nisbet, I.C.T., Monticelli, David, Spendelow, J.A., Szczys, Patricia, and Frederiksen, Morten, eds., 2016, Pre-breeding survival of roseate terns Sterna dougallii varies with sex, hatching order and hatching date: Ibis, v. 158, no. 2, p. 327-334, http://dx.doi.org/10.1111/ibi.12359.

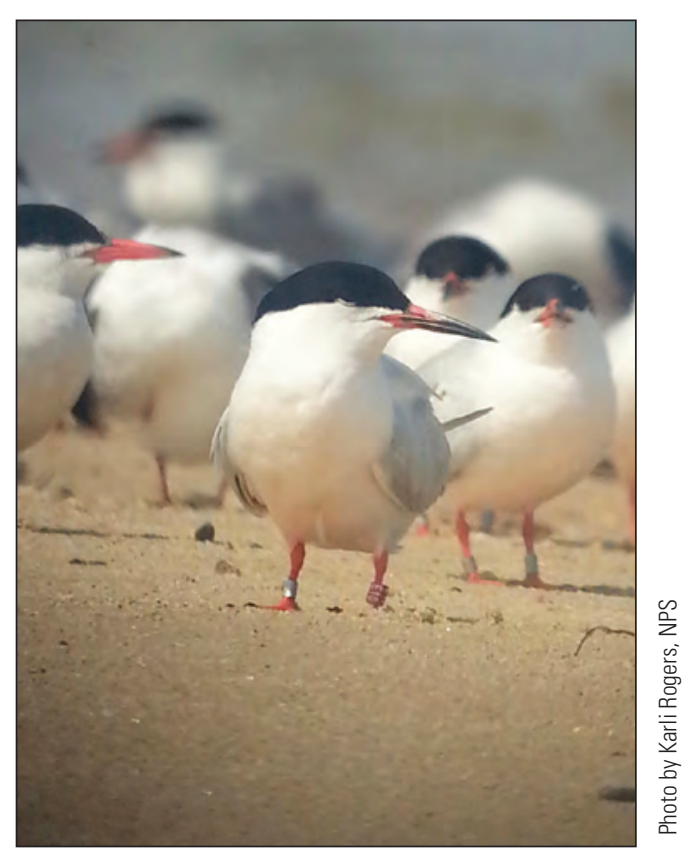

Endangered northwest Atlantic roseate tern. 


\section{Survey of Biological Hotspots in the Gulf of Maine Coastal Marine Ecosystem}

The USGS is collecting data needed to inform management needs and increase the understanding of the ecologically and economically productive Gulf of Maine ecosystem. This endeavor will be achieved through multidisciplinary surveys, combined with research on life-history characteristics of selected species, to acquire detailed measurements of the physical characteristics of the system as well as the distribution and abundance of organisms across food webs. These data will be used to build habitat models for species of greatest concern and to calculate biological hotspot index values. This information can support planning efforts and habitat management by delineating ecologically important areas. This project will also provide critical baseline data for monitoring and evaluating future changes to the region.

Contact

Cynthia Loftin, USGS Maine Cooperative Fish and Wildlife Unit; cynthia.loftin@maine.edu; (207) 581-2843

\section{The Pacific}

\section{Pacific Continental Shelf Environmental Assessment}

Understanding critical marine habitats, including seabird and marine mammal hotspots at sea, will help inform offshore energy siting along the U.S. Pacific Coast. The USGS recently completed seabird and marine mammal surveys for the BOEM Pacific Outer Continental Shelf (OCS) region to inform future alternative energy plans. The primary survey area, named the Pacific Continental Shelf Environmental Assessment, extends from Fort Bragg, California, to Grays Harbor, Washington. Marine spatial planning, including potential site selection for offshore energy development, requires updated information on species-specific community patterns and distributions in this region. The USGS is using aircraft surveys to conduct seabird and marine mammal counts concurrently with oceanographic remote-sensing equipment to record habitat features throughout this span of the Pacific OCS region and is compiling regional at-sea

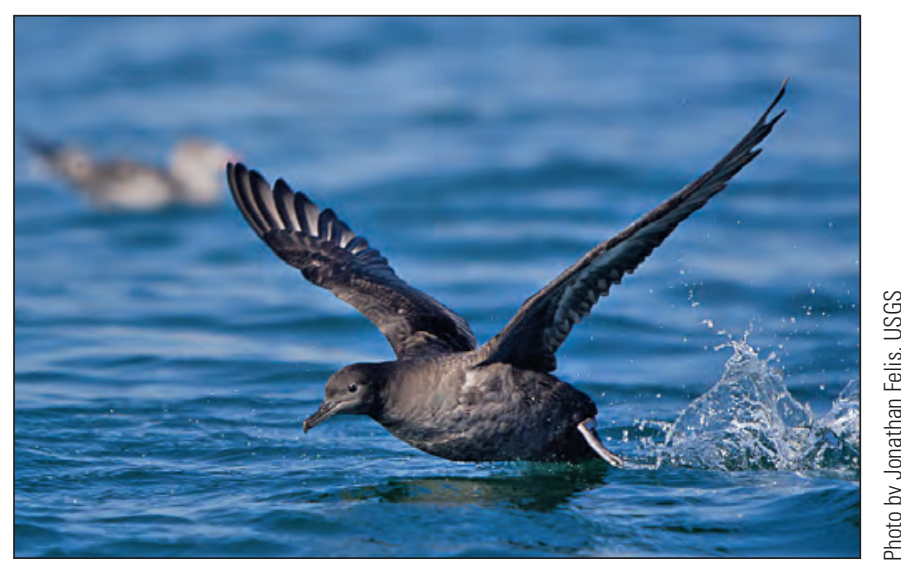

A sooty shearwater (Ardenna grisea) takes off just offshore of Capitola, Calif. tracking data from marine birds to create an atlas illustrating habitat-use patterns for multiple species. This work will increase the understanding of overall species distribution patterns throughout the California Current System.

\section{Contact}

Josh Adams, USGS Western Ecological Research Center; josh_adams@usgs.gov; (831) 460-7566

\section{Publications}

Adams, Josh, Felis, J.J., Mason, J.W., and Takekawa, J.Y., 2014, Pacific Continental Shelf Environmental Assessment (PaCSEA)—Aerial seabird and marine mammal surveys off northern California, Oregon, and Washington, 2011-2012 - Data summary: Camarillo, Calif., Bureau of Ocean Energy Management, U.S. Department of the Interior, OCS Study BOEM 2014-003, 266 p., https://www.sciencebase.gov/ catalog/item/55773437e4b032353cba3080.

Adams, Josh, Felis, J.J., Mason, J.W., and Takekawa, J.Y., 2015, Pacific Continental Shelf Environmental Assessment (PaCSEA) GIS resource database-Aerial seabird and marine mammal surveys off northern California, Oregon, and Washington, 2011-2012: U.S. Geological Survey Data Release, http://dx.doi.org/10.5066/F7668B7V.

\section{Seabird Vulnerability Assessment for Renewable Energy Projects}

The eastern Pacific supports abundant breeding seabirds, shorebirds, and other waterbirds, including species protected under the Migratory Bird Treaty Act and Endangered Species Act. Whereas data on distribution and abundance of seabirds can inform decisions regarding the siting of renewable energy projects, more comprehensive site evaluations require an understanding of species-specific variability in habitat use, ranging behaviors, and cumulative threats at sea. The USGS is conducting research to increase the understanding of the flight and diving behavior of seabirds and to combine this information with knowledge of the seasonal distribution and abundance among birds at sea in order to rank and assess population collision vulnerability and population displacement vulnerability among 81 species of marine birds inhabiting the California Current System of the Pacific OCS.

\section{Contact}

Josh Adams, USGS Western Ecological Research Center; josh_adams@usgs.gov; (831) 460-7566 


\section{Predictive Modeling of Marine Bird Spatial Distributions on the Pacific Outer Continental Shelf}

The States of California, Oregon, and Washington are engaged with BOEM in various ways to plan the siting of offshore energy projects within the territorial sea and OCS regions. The USGS and collaborators are using at-sea transect survey and individual tracking data throughout the Pacific OCS in addition to oceanographic and environmental data to develop predictive models on distribution and abundance and hotspot/coldspot areas and relative bird occurrence and abundance throughout a large region of the California Current System.

Contact

Josh Adams, USGS Western Ecological Research Center; josh_adams@usgs.gov; (831) 460-7566

\section{Main Hawaiian Islands Seabird Tracking}

The Main Hawaiian Islands and associated offshore areas provide substantial breeding habitat for more than 19 seabird species. The BOEM and the State of Hawaii have received proposals to develop offshore renewable energy-related projects within waters surrounding the main islands. These projects have the potential to negatively affect seabirds through interactions with wind-turbine structures, lighted facilities, elevated power lines on land, and lighted ships offshore. The USGS, in collaboration with others, is continuing at-sea tracking studies of seabirds in this area to provide information to assess potential risks posed by proposed offshore energy developments. Information collected includes intra- and inter-seasonal and inter-colony differences in foraging behaviors, variability in sea habitat use, and ranging behaviors among seabird species including two species listed under the U.S. Endangered Species Act - the Hawaiian petrel (Pterodroma sandwichensis) and Newell's shearwater (Puffinus newelli).

\section{Contact}

Josh Adams, USGS Western Ecological Research Center; josh_adams@usgs.gov; (831) 460-7566

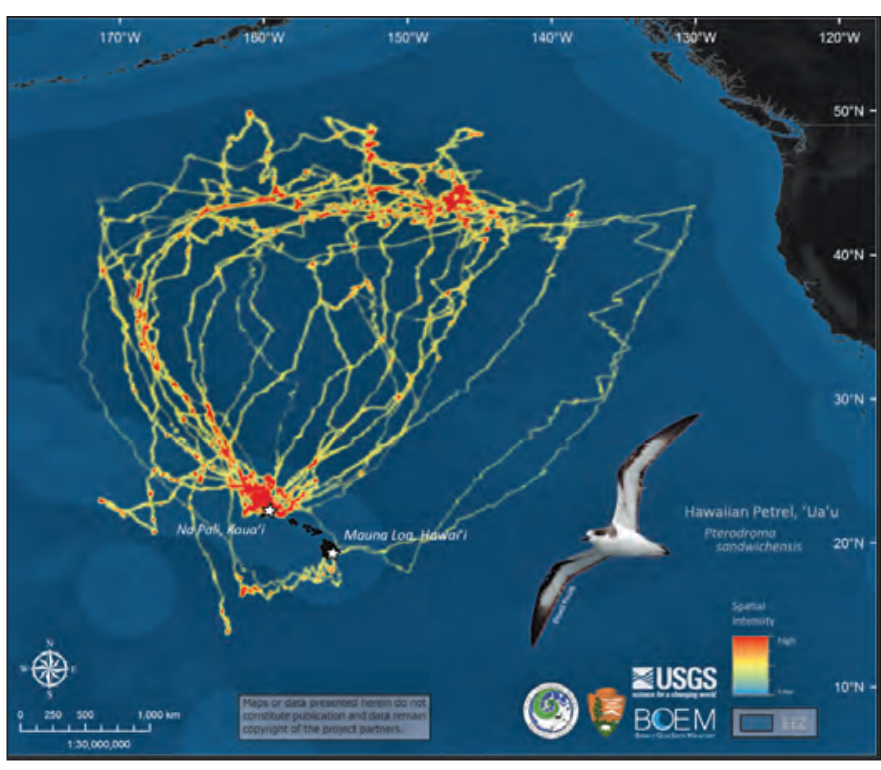

Hawaiian petrel at-sea movements from several breeding colonies in Hawaii (from USGS, http://www.werc.usgs.gov/ProjectSubWebPage. aspx?SubWebPagelD=3\&Project|D=254)

\section{North Pacific Pelagic Seabird Survey Data}

The USGS has released the North Pacific Pelagic Seabird Database, an online resource compiling the results of 40 years of surveys by biologists from the United States, Canada, Japan, and Russia. The database documents the abundance and distribution of 160 seabird and 41 marine mammal species over a 10-million-square-mile region of the North Pacific. This database offers a powerful tool for analysis of climate change effects on marine ecosystems of the Arctic and North Pacific and for monitoring the impact of fisheries, vessel traffic, and oil development on marine bird communities over a vast region. It also creates an unprecedented opportunity to study the biogeography and marine ecology of dozens of species of seabirds and marine mammals throughout their range in continental shelf waters of the United States.

\section{Contacts}

John Piatt, USGS Alaska Science Center; jpiatt@usgs.gov; (360) 774-0516

Gary Drew, USGS Alaska Science Center; gdrew@usgs.gov; (907) 786-7168

\section{Publication}

Drew, G.S., Piatt, J.F., and Renner, M., 2015, User's guide to the North Pacific Pelagic Seabird Database 2.0: U.S. Geological Survey Open-File Report 2015-1123, 52 p., http://dx.doi.org/10.3133/ofr20151123.

\section{Status of Seabirds and Forage Fish in Cook Inlet, Alaska}

Seabird densities in lower Cook Inlet are among the highest in Alaska, which is one reason this location suffered the greatest damage to marine bird populations from the Exxon Valdez oil spill. Large resident and migratory seabird populations are sustained by locally abundant stocks of key forage fish species. Monitoring of seabird populations and forage fish stocks in potential oil and gas lease areas has been a BOEM priority, both to mitigate impacts of development and to assess the impact 
of potential oil spills. Following intensive investigations of seabirds and forage fish in lower Cook Inlet during 1995-2000, collection of such data in lower Cook Inlet has been limited. USGS is collecting new data in 2016-19 to update our knowledge on forage fish and seabird populations in Cook Inlet and to support environmental analysis for potential lease sales and associated activities in Cook Inlet during 2017 and beyond.

Contact

John Piatt, USGS Alaska Science Center; jpiatt@usgs.gov; (360) 774-0516

\section{Integrated Predator-Prey Surveys: Humpback Whales, Marine Birds, Forage Fish}

In collaboration with National Oceanic and Atmospheric Administration (NOAA), USFWS, and Prince William Sound Science Center, the USGS is leading an integrated study of whales, seabirds, and forage fish funded under the Gulf Watch program of the Exxon Valdez Oil Spill Trustee Council. From 2017 to 2022, the USGS plans to integrate three different predator studies with an ongoing study of forage fish to obtain comparable information on both predator density and prey availability. The forage fish survey will focus on prey availability, distribution relative to predators and geography, energy density, and water column depth. Seabird diet sampling at nearby Middleton Island will add to the understanding of population dynamics of key forage species in the Gulf of Alaska, including capelin (Mallotus villosus), sand lance (Ammodytes marinus), myctophids, Pacific herring (Clupea pallasi), juvenile sablefish (Anoplopoma fimbria), and hatchery-produced juvenile pink (Oncorhynchus gorbuscha) and chum salmon (O. keta) from Prince William Sound and southeast Alaska.

\section{Contacts}

Mayumi Arimitsu, USGS Alaska Science Center; marimitsu@usgs.gov; (907) 364-1593

John Piatt, USGS Alaska Science Center; jpiatt@usgs.gov; (360) 774-0516

\section{The Gulf of Mexico}

\section{Spatial and Reproductive Ecology of Brown Pelicans in the Gulf of Mexico}

Although the Gulf of Mexico contains a high density of oil infrastructure as well as a rich assemblage of seabirds, baseline data on at-sea distribution and habitat use of these species are poorly understood. Given its distribution patterns, behavior, and known sensitivity to chemical and oil contaminants exposure, the brown pelican (Pelecanus occidentalis) is a focal species for investigations of risk exposure in the marine environment. The USGS is leading a study focusing on colony-specific movement patterns, habitat use at sea, and reproductive parameters for brown pelicans across the northern Gulf from Corpus Christi Bay to the Florida Panhandle. USGS scientists deployed GPS satellite tags on 85 adult pelicans breeding in the region to assess spatial ecology. Data were also collected on colony diet, behavior, and reproduction. Data may be used by the BOEM, USFWS, State agencies, and the Gulf Avian Monitoring Network to develop management plans and future research and monitoring efforts.

Contact

Patrick Jodice, USGS South Carolina Cooperative Fish and Wildlife Research Unit; pjodice@clemson.edu; (864) 656-6190

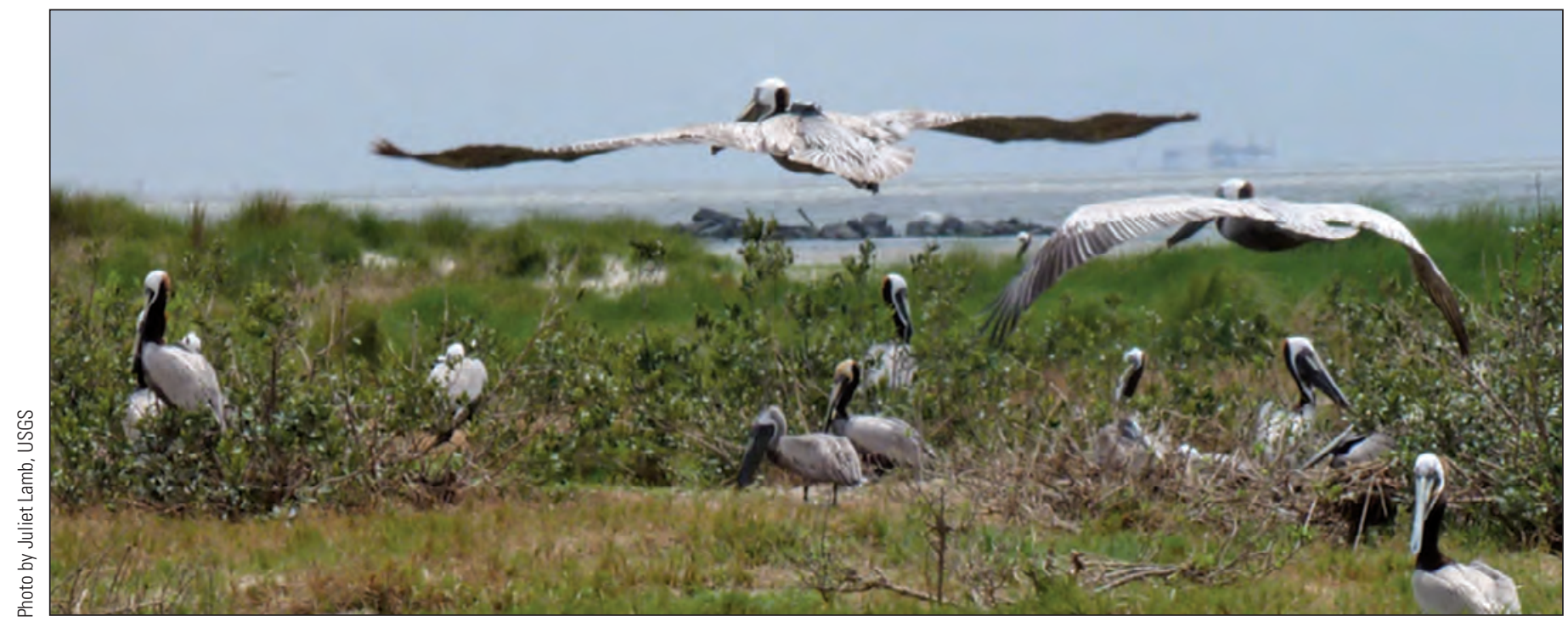

Brown Pelican at breeding colony, Raccoon Island, La. 


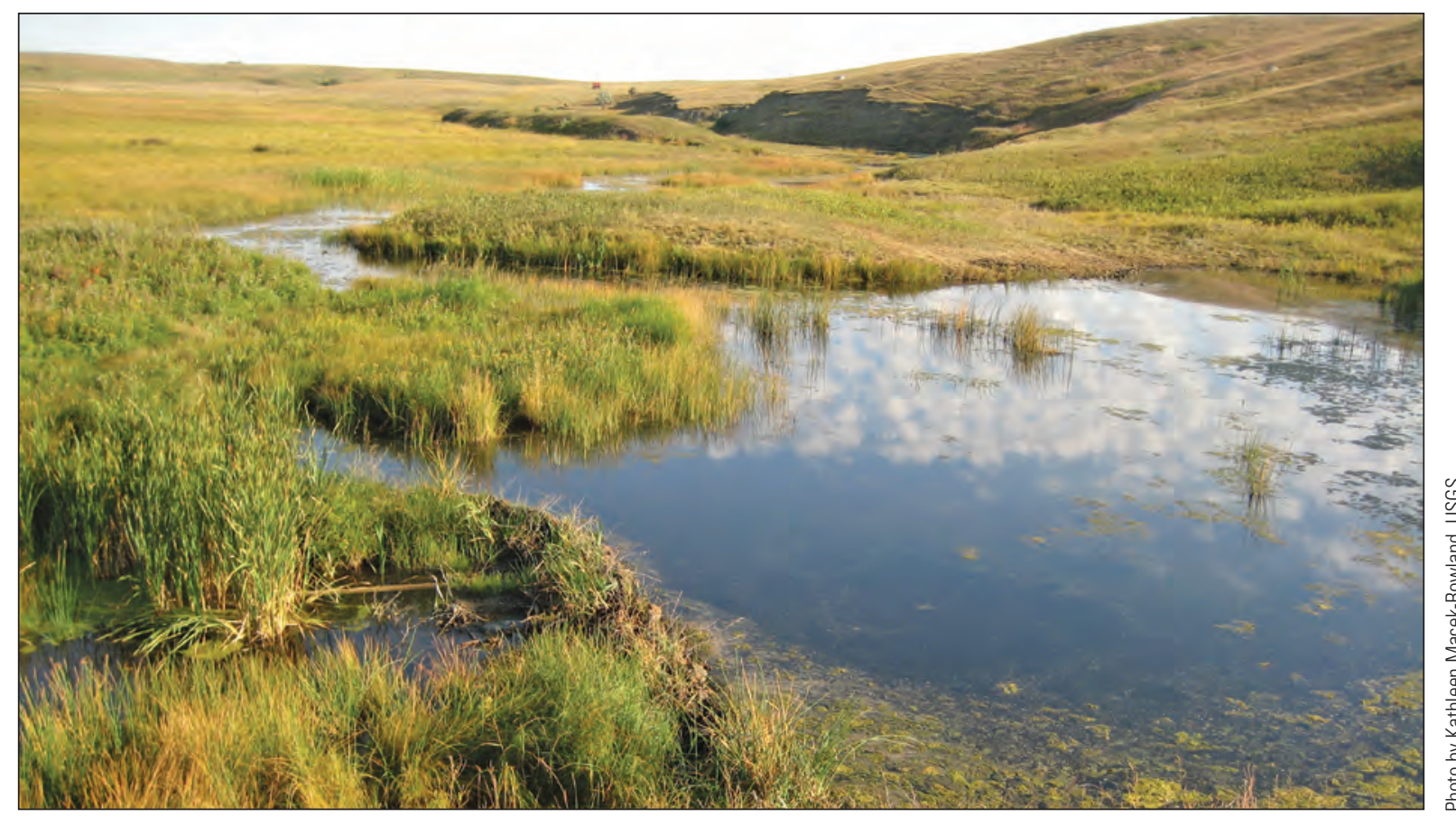

A meandering stream in North Dakota.

\section{Grassland Birds and Waterbirds}

\section{Northern Prairie and the Great Plains}

\section{Direct Mortality to Avifauna From Wind Energy Facilities in the Dakotas}

Potential impacts of large wind energy developments to migratory and resident bird populations in the Prairie Pothole Region within North Dakota and South Dakota remain understudied even though 2,230 turbines are actively generating power in these States and numerous wind energy projects have been proposed. No information on potential direct mortality from wind turbines is available for the Missouri Coteau portion of the region across multiple avian guilds. The USGS is leading a study to evaluate the influence of landscape composition on potential wind turbine-related direct mortality to migratory and resident birds in the south-central Missouri Coteau during spring migration and nesting periods. The study will also evaluate the influence of nesting density on wind turbine-related direct mortality of raptors, identify those species most at risk to mortality from wind-turbine strikes, and calculate fatality rates for species of concern.

\section{Contact}

Joshua Stafford, South Dakota Cooperative Fish and Wildlife Research Unit; joshua.stafford@sdstate.edu; (605) 688-5759

\section{Publication}

Graff, B.J., Jenks, J.A., Stafford, J.D., Jensen, K.C., and Grovenburg, T.W., 2016, Assessing spring direct mortality to avifauna from wind energy facilities in the Dakotas: Journal of Wildlife Management, v. 80, no. 4, p. 736-745, http://dx.doi.org/10.1002/jwmg.1051.

\section{Wind Energy Effects on Distribution of Grassland Birds in the Dakotas}

The USGS has completed a 10-year field study of the influence of wind facilities on breeding grassland birds. The study showed that wind facilities placed in mixed-grass prairies influence the distribution of grassland birds for years after construction. The study included a before-after-control-impact, or BACI, design that incorporated multiple years, nine species, and replicated impact and reference sites within three facilities. The approach is one of the most rigorous uses of an optimal impact assessment design to evaluate wind facilities. This long-term study distinguished between immediate, short-term effects, and delayed or sustained effects. The study also determined distances at which individual bird species displayed avoidance or attraction to wind facilities.

\section{Contact}

Jill Shaffer, USGS Northern Prairie Wildlife Research Center; jshaffer@usgs.gov; (701) 253-5547

\section{Publication}

Shaffer, J.A., and Buhl, D.A., 2015, Effects of wind-energy facilities on grassland bird distributions: Conservation Biology, v. 30, no. 1, p. 59-71, http://dx.doi.org/10.1111/cobi.12569. 


\section{Avoidance of Oil Wells and Roads Exacerbates Habitat Loss for Grassland Birds}

Oil development in the shale region of the Bakken Formation in Montana and North Dakota has increased rapidly as a result of new technologies and strong demand for fossil fuel. This region also supports a particularly high density and diversity of grassland bird species, which are declining across North America. The USGS led a study to examine grassland bird response to unconventional oil extraction sites and associated roads in North Dakota. This study quantifies environmental degradation caused by oil development to assist managers in understanding how to better mitigate potential harm to wildlife populations from this development.

\section{Contact}

Douglas H. Johnson, USGS Northern Prairie Wildlife Research Center; douglas_h_johnson@usgs.gov; (612) 624-4716

\section{Publication}

Thompson, S.J., Johnson, D.H., Nieumuth, N.D., and Ribic, C.A., 2015, Avoidance of unconventional oil wells and roads exacerbates habitat loss for grassland birds in the North American Great Plains: Biological Conservation, v. 192, p. 82-90, http://dx.doi.org/10.1016/ j.biocon.2015.08.040.

\section{Birds and the Bakken Formation: Integration of Oil Well, Land Cover, and Species Distribution Data to Inform Conservation}

The USGS is leading a project that will measure the effects of well development on birds in the Williston Basin in eastern Montana, western North Dakota, and South Dakota. Researchers will create maps that combine data on habitat conversion and species distribution to describe the effects of disturbance from oil well pads on biodiversity. Models will also be developed to display past and potential future effects of energy development on grassland birds. This information can assist managers with prioritizing areas for conservation in the Williston Basin.

Contact

Todd Preston, USGS Northern Rocky Mountain Science Center; tmpreston@usgs.gov; (406) 994-5034

\section{Lesser Prairie-Chicken Population and Habitat Ecology}

The lesser prairie-chicken (Tympanuchus pallidicinctus) currently occupies a range that includes portions of Colorado, Kansas, New Mexico, Oklahoma, and Texas. This species has experienced population declines due to both direct and indirect habitat loss, including conversion of native rangeland to cropland and disturbance from energy development. A new study by the USGS and collaborators predicts habitat suitability for lesser prairie-chicken leks by exploring lesser prairie-chicken occurrence in relation to landscape characteristics such as land cover and anthropogenic effects such as distance to active wells, roads, highways, transmission lines, and tall structures. Habitat suitability models, combined with other landscape information, form the basis of a habitat assessment tool that can be used to guide siting of development projects and targeting of areas for conservation.

\section{Contacts}

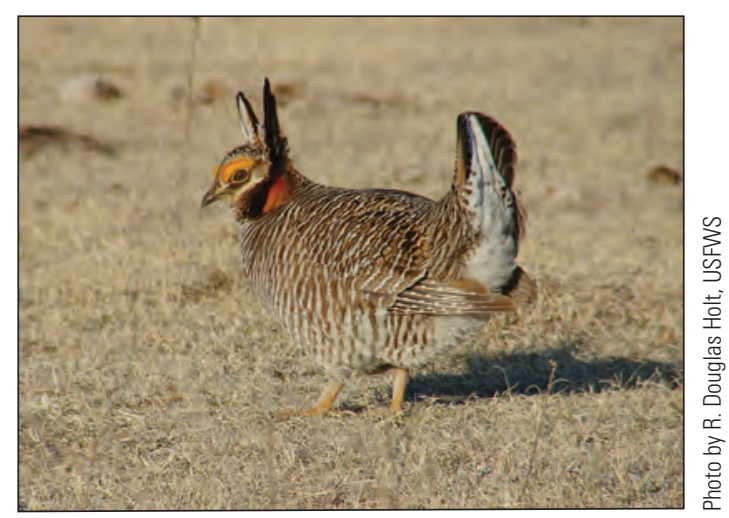

Lesser prairie-chicken.

Catherine Jarnevich, USGS Fort Collins Science Center; jarnevichc@usgs.gov; (970) 226-9439

Dave Haukos, USGS Kansas Cooperative Fish and Wildlife Research Unit; dhaukos@ksu.edu; (785) 532-5761

Clint Boal, USGS Texas Cooperative Fish and Wildlife Research Unit; cboal@usgs.gov; (806) 742-2851

Scott Carleton, USGS New Mexico Cooperative Fish and Wildlife Research Unit; scarleton@usgs.gov; (575) 646-7196

\section{Publications}

Boal, C.W., and Pirius, N.E., 2012, Winter ecology and habitat use of lesser prairie-chickens in west Texas, 2008-11: U.S. Geological Survey Open-File Report 2012-1073, 9 p., http://pubs.usgs.gov/of/2012/1073/.

Grisham, B.A., Borsdorf, P.K., Boal, C.W., and Boydston, K.K., 2014, Nesting ecology and nest survival of lesser prairie-chickens on the southern High Plains of Texas: The Journal of Wildlife Management, v. 78, no. 5, p. 857-866, http://dx.doi.org/10.1002/jwmg.716.

Haukos, D.A., and Boal, C.W., eds., 2016, Ecology and conservation of lesser prairie-chickens: Boca Raton, Fla., CRC Press, 376. p.

Jarnevich, C.S., Holcombe, T.R., Grisham, B.A., Timmer, Jennifer, Boal, C.W., Butler, M.J., Pitman, James, Kyle, S.C., Klute, David, Beauprez, G.M., Janus, Allan, and Van Pelt, W.E., 2016, Assessing range-wide habitat suitability for the lesser prairie-chicken: Avian Conservation and Ecology, v. 11, no. 1, unpaginated, http://dx.doi.org/10.5751/ace-00807-110102. 
Jarnevich, C.S., and Laubhan, M.K., 2011, Balancing energy development and conservation-A method utilizing species distribution models: Environmental Management, v. 47, no. 5, p. 926-936, http://dx.doi.org/10.1007/s00267-011-9651-2.

Timmer, J.M., Butler, M.J., Ballard, W.B., Boal, C.W., and Whitlaw, H.A., 2013, Abundance and density of lesser prairie-chickens and leks in Texas: Wildlife Society Bulletin, v. 37, no. 4, p. 741-749, http://dx.doi.org/10.1002/wsb.304.

\section{Indirect Effects of Wind Energy Development on Breeding Grassland Songbirds}

Emphasis has been placed on determining the direct mortality of birds and bats in the vicinity of wind energy facilities, yet determining the indirect effects of these facilities on breeding birds, such as decreased breeding success, is also important. USGS researchers recently evaluated the reproductive success of two grassland songbirds, McCown's longspur (Rhynchophanes mccownii) and horned lark (Eremophila alpestris) in 2011 and 2012, in relation to turbine density and the proximity to the nearest wind turbine. Horned lark nestling size and nest survival decreased with turbine density during the first year of the study, whereas longspur reproductive metrics were unrelated to development. Results from this study can be used to help inform wind farm design that minimizes impacts to the reproductive success of grassland birds. Additional studies across other ecological contexts (regions, habitats, species, wind farms) are needed to delineate general trends in species' responses to wind energy facilities.

\section{Contact}

Anna Chalfoun, USGS Wyoming Cooperative Fish and Wildlife Research Unit; achalfoun@usgs.gov; (307) 766-6966

\section{Publication}

Mahoney, Anika, and Chalfoun, A.D., 2016, Reproductive success of Horned Lark and McCown's Longspur in relation to wind energy infrastructure: The Condor, v. 118, no. 2, p. 360-375, http://dx.doi.org/10.1650/condor-15-25.1.

\section{Whooping and Sandhill Cranes}

\section{Landscape and Airspace Use of Waterbirds}

The USGS and USFWS have partnered to collect data on foraging locations and flight patterns of fall refuging sandhill cranes (Grus canadensis) within the Horicon Marsh landscape in southeastern Wisconsin, including an 86-turbine wind energy facility. A three-dimensional crane movement model is being developed based on crane habitat use probabilities, turbine avoidance probabilities, and flight profiles. The model framework can be used to estimate landscape and airspace use of refuging waterbird species in different areas to evaluate placement options for wind energy projects and transmission lines.

\section{Contact}

Eileen Kirsch, USGS Upper Midwest Environmental Sciences Center; ekirsch@usgs.gov; (608) 781-6226

\section{Publication}

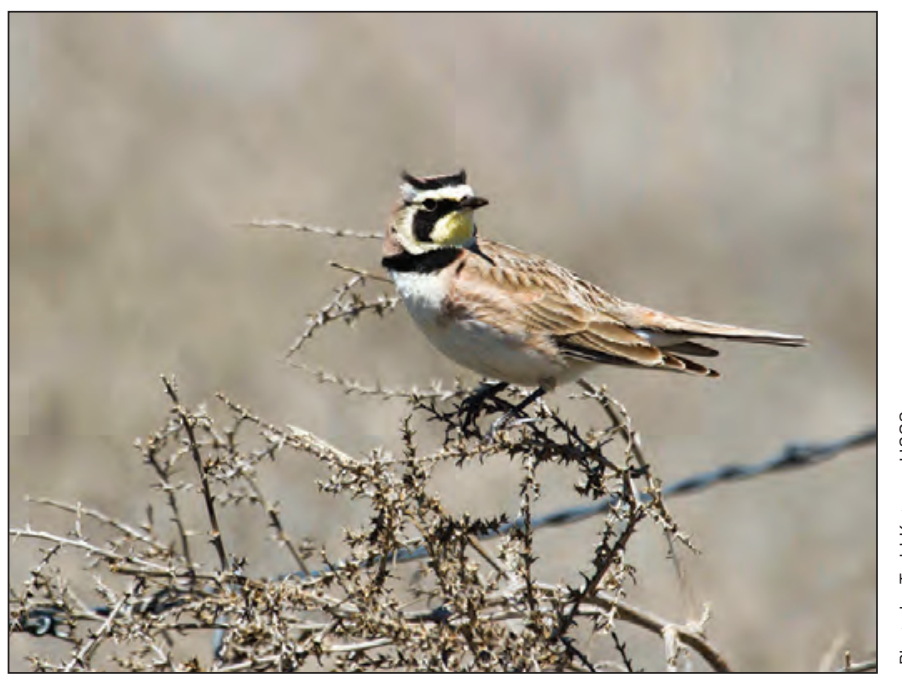

Horned lark.

Kirsch, E.M., Wellik, M.J., Suarez, Manuel, Diehl, R.H., Lutes, Jim,

Woyczik, Wendy, Krapfl, Jon, and Sojda, Richard, 2015, Observations of sandhill cranes' (Grus canadensis) flight behavior in heavy fog:

The Wilson Journal of Ornithology, v. 127, no. 2, p. 281-288, http://dx.doi.org/10.1676/wils-127-02-281-288.1. 


\section{Whooping Crane Stopover Site Use Intensity Within the Great Plains}

Whooping cranes (Grus americana) of the Aransas-Wood Buffalo population migrate twice each year through the Great Plains in North America between Canada and Texas. To assist with identification of more intensively used areas across the whooping crane migration range and help with the recovery efforts of this population of whooping cranes, the USGS calculated initial estimates of stopover site use intensity. This evaluation offers the USFWS and partners a tool to identify landscapes that may be of conservation importance to migrating whooping cranes.

Contact

Aaron Pearse, USGS Northern Prairie Wildlife Research Center; apearse@usgs.gov; (701) 253-5509

\section{Publication}

Pearse, A.T., Brandt, D.A., Harrell, W.C., Metzger, K.L., Baasch, D.M., and Hefley, T.J., 2015, Whooping crane stopover site use intensity within the Great Plains: U.S. Geological Survey Open-File Report 2015-1166, http://dx.doi.org/10.3133/ofr20151166.

\section{Sandhill Crane Exposure to Wind Energy Development in the Great Plains}

Numerous wind energy farms have been constructed in the central and southern Great Plains, the main migration corridor and wintering area for midcontinent sandhill cranes. Crane populations are potentially vulnerable to wind energy infrastructure, specifically increased mortality due to collisions and displacement from roosting or feeding sites. The USGS has assessed the potential risk of wind towers to the crane population by using location data from cranes marked with platform transmitter terminals with and without global positioning system capabilities. The distributions of sandhill cranes prior to construction of wind towers were compared to distributions with current tower locations. This assessment provides an estimate of the potential risk to the midcontinent population of sandhill cranes at their main migration and wintering grounds, information for local-scale decisions about the relative risk of existing towers, information for locating future developments, and data that can be combined with assessments from other species to develop multispecies risk models.

Contact

Aaron Pearse, USGS Northern Prairie Wildlife Research Center; apearse@usgs.gov; (701) 253-5509

\section{Publication}

Pearse, A.T., Brandt, D.A., and Krapu, G.L., 2016, Wintering sandhill crane exposure to wind energy development in the central and southern Great Plains, U.S.A.: The Condor, v. 118, no. 2, p. 391-401, http://dx.doi.org/10.1650/condor-15-99.1.

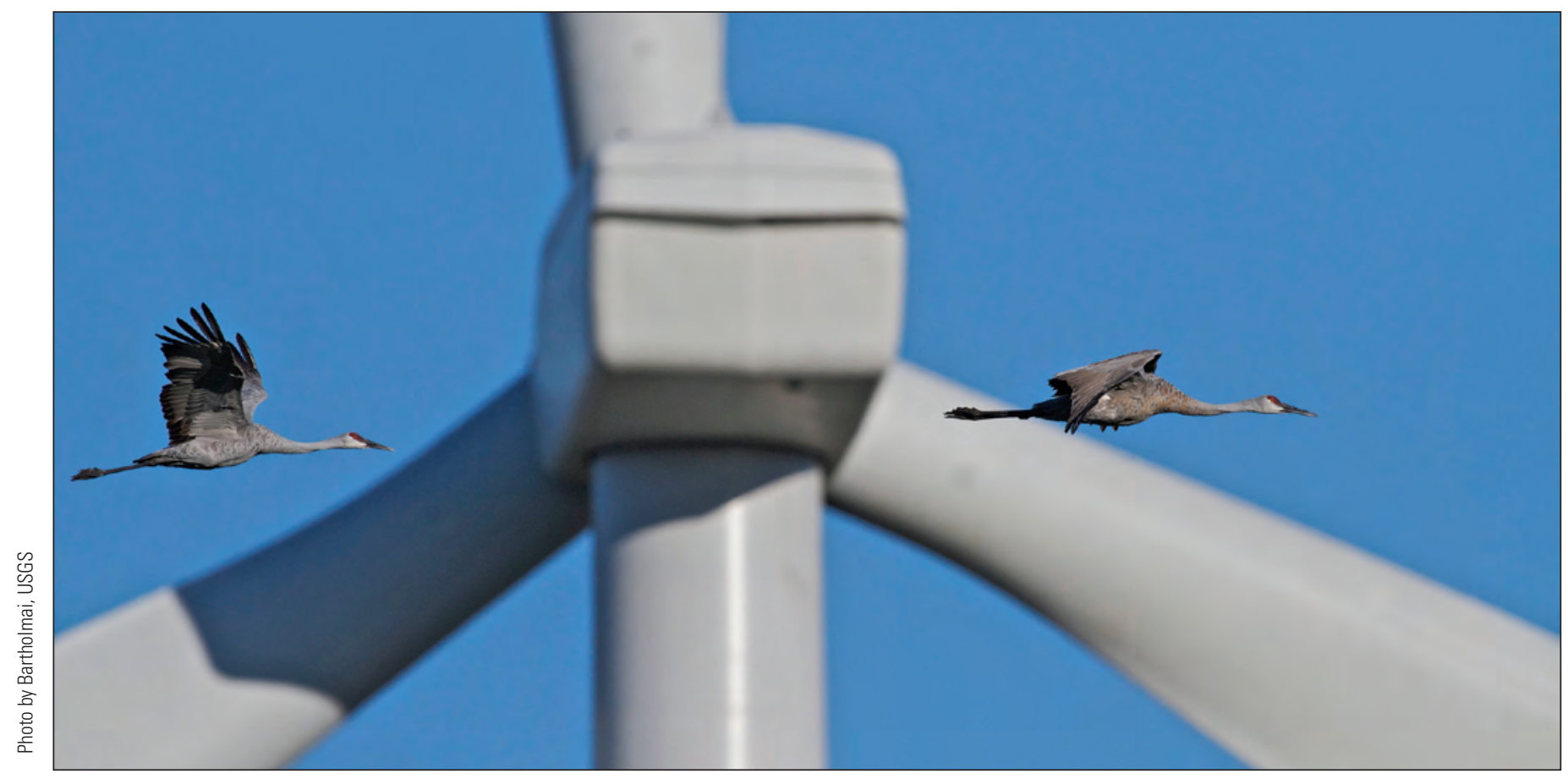

Sandhill cranes and wind turbines near Horicon National Wildlife Refuge, Wis. 


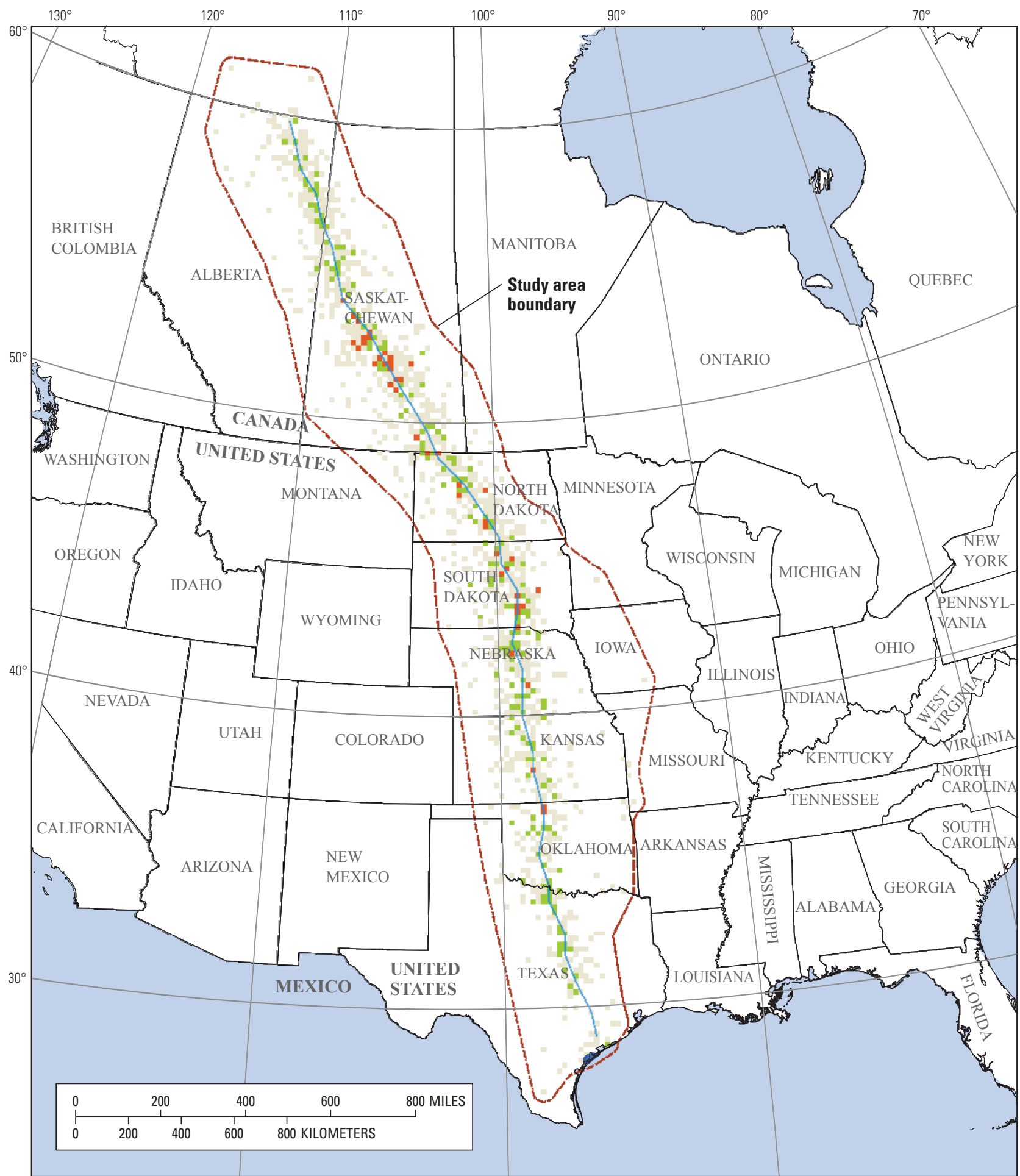

Base map from Esri and used herein under license (500-meter resolution) Universal Transverse Mercator projection, zones 13-14 N North American Datum of 1983

\section{EXPLANATION}

Whooping crane migration corridor

Low intensity

Core intensity

Extended-use core intensity

Centerline

Stopover site use intensity areas within the migration corridor of whooping cranes (from Pearse and others, 2015). 


\section{Birds in the Intermountain West}

\section{Renewable Energy Development and Nevada Greater Sage-Grouse}

Much of Nevada is under consideration for proposed energy transmission corridors linking Wyoming, eastern Nevada, and the Mojave Desert. Potential paths for the corridor will fragment prime, contiguous sagebrush-steppe habitat. The USGS, in collaboration with other Federal and State agencies and private industry, is conducting greater sage-grouse (Centrocercus urophasianus) research to understand the effects of wind energy development in Nevada and how structures, such as power lines and their associated corridors, influence predator communities and predation rates on sage-grouse. The goal of the project is to answer questions related to impacts of developing energy on sage-grouse habitat selection, population vital rates, and movement patterns. This research provides resource managers with information and tools to help develop guidelines for future renewable energy projects to minimize negative effects on greater sage-grouse populations.

Contacts

Peter Coates, USGS Western Ecological Research Center; pcoates@usgs.gov; (530) 669-5073

Michael Casazza, USGS Western Ecological Research Center; mike_casazza@usgs.gov; (530) 669-5075

\section{Publications}

Coates, P.S., Casazza, M.L., Brussee, B.E., Ricca, M.A., Gustafson, K.B., Overton, C.T., Sanchez-Chopitea, Erika, Kroger, Travis, Mauch, Kimberly, Niell, Lara, Howe, Kristy, Gardner, Scott, Espinosa, Shawn, and Delehanty, D.J., 2014, Spatially explicit modeling of greater sage-grouse (Centrocercus urophasianus) habitat in Nevada and northeastern California-A decision-support tool for management: U.S. Geological Survey Open-File Report 2014-1163, http://dx.doi.org/10.3133/ofr20141163.

Coates, P.S., Casazza, M.L., Ricca, M.A., Brussee, B.E., Blomberg, E.J., Gustafson, K.B., Overton, C.T., Davis, D.M., Niell, L.E., Espinosa, S.P., Gardner, S.C., and Delehanty, D.J., 2015, Integrating spatially explicit indices of abundance and habitat quality-An applied example for greater sage-grouse management: Journal of Applied Ecology, v. 53, no. 1, p. 83-95, http://dx.doi.org/10.1111/1365-2664.12558.

Coates, P.S., Howe, K.B., Casazza, M.L., and Delehanty, D.J., 2014, Common raven occurrence in relation to energy transmission line corridors transiting human-altered sagebrush steppe: Journal of Arid Environments, v. 111, p. 68-78, http://dx.doi.org/10.1016/j. jaridenv.2014.08.004.

\section{Implications of Anthropogenic Activities on Greater Sage-Grouse Populations in Nevada}

The USGS has initiated a study at nine sites across Nevada to answer questions related to long-term and short-term effects of disturbance caused by wind turbines, gold mining, geothermal energy production, hydraulic fracturing for oil, and transmission line development on sage-grouse habitat selection, population vital rates, and movement patterns. This information will help managers develop guidelines that strive to minimize negative effects of these activities on greater sage-grouse and their associated habitat. Contact

Peter Coates, USGS Western Ecological Research Center; pcoates@usgs.gov; (530) 669-5073

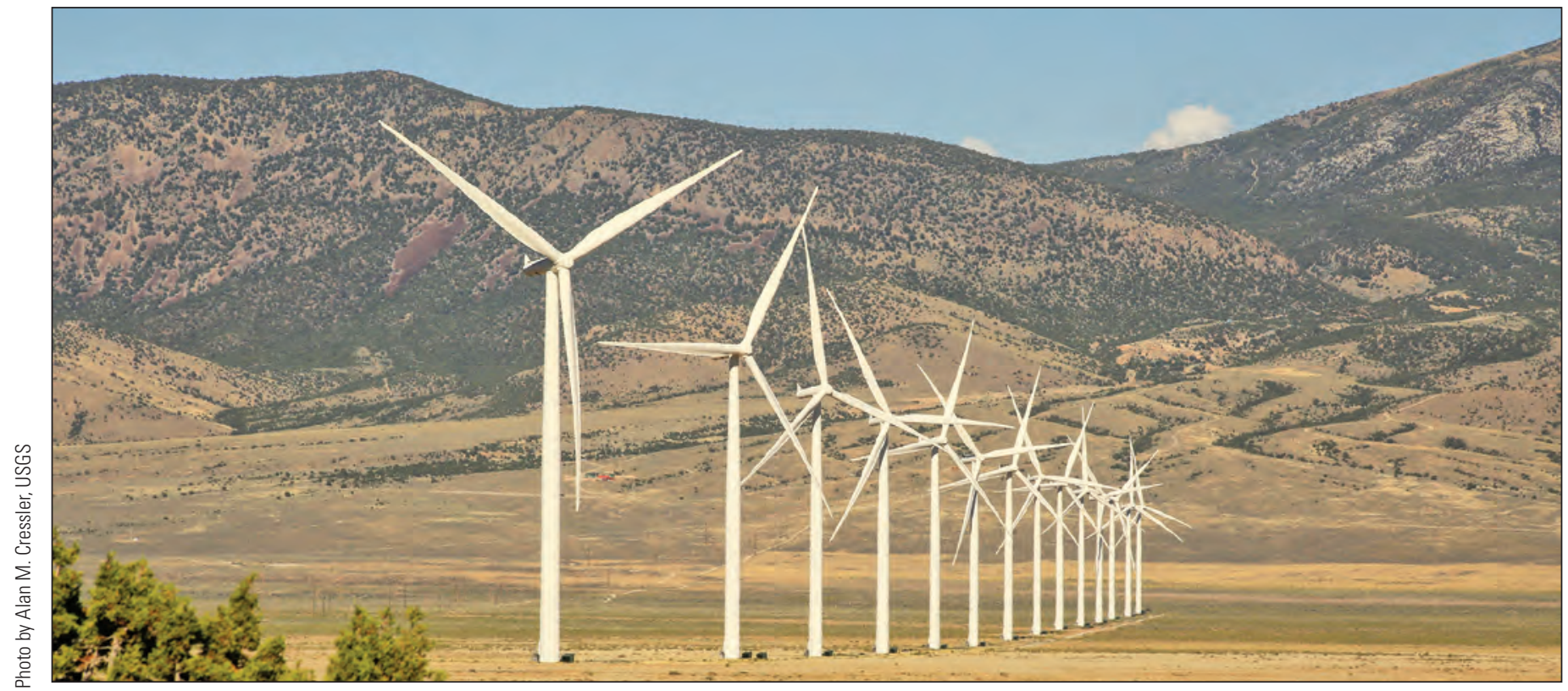

Wind energy facility in White Pine County, Nev. 


\section{Breeding Sagebrush Songbird Responses to Gas Development: Patterns and Mechanisms}

Ongoing USGS research since 2008 in two natural gas fields, Pinedale Anticline and the Jonah Field, in western Wyoming has documented patterns in the abundance and nesting success of the three sagebrush-obligate passerine birds-Brewer's sparrow (Spizella breweri), sagebrush sparrow (Artemisiospiza nevadensis), and sage thrasher (Oreoscoptes montanus) - the populations of which are declining in at least parts of their habitat range. Abundance of the two sparrow species decreased with the increased density of natural gas wells, and during at least some years of the study all three species experienced lower nest survival in areas with greater surrounding habitat loss due to natural gas development. The primary cause of nest failures in the study area is nest predation, and the primary predator species identified by infrared camera units have been rodents, such as deer mice, chipmunks, and ground squirrels. An important next step is to investigate why the activity and (or) abundance of rodent species have increased with surrounding habitat loss from energy extraction, so that management practices may be implemented to discourage the local accumulation of rodent nest predators.

\section{Contact}

Anna D. Chalfoun, USGS Wyoming Cooperative Fish and Wildlife Research Unit; achalfoun@usgs.gov; (307) 766-6966

\section{Publications}

Gilbert, M.M., and Chalfoun, A.D., 2011, Energy development affects populations of sagebrush songbirds in Wyoming: Journal of Wildlife Management, v. 75, no. 4, p. 816-824, http://dx.doi.org/10.1002/jwmg.123.

Hethcoat, M.G., and Chalfoun, A.D., 2015, Energy development and avian nest survival in Wyoming, U.S.A.-A test of a common disturbance index: Biological Conservation, v. 184, p. 327-334, http://dx.doi.org/10.1016/j.biocon.2015.02.009.

Hethcoat, M.G., and Chalfoun, A.D., 2015, Toward a mechanistic understanding of human-induced rapid environmental change-A case study linking energy development, avian nest predation, and nest predators: Journal of Applied Ecology, v. 52, no. 6, p. 1492-1499, http://dx.doi.org/10.1111/1365-2664.12513.

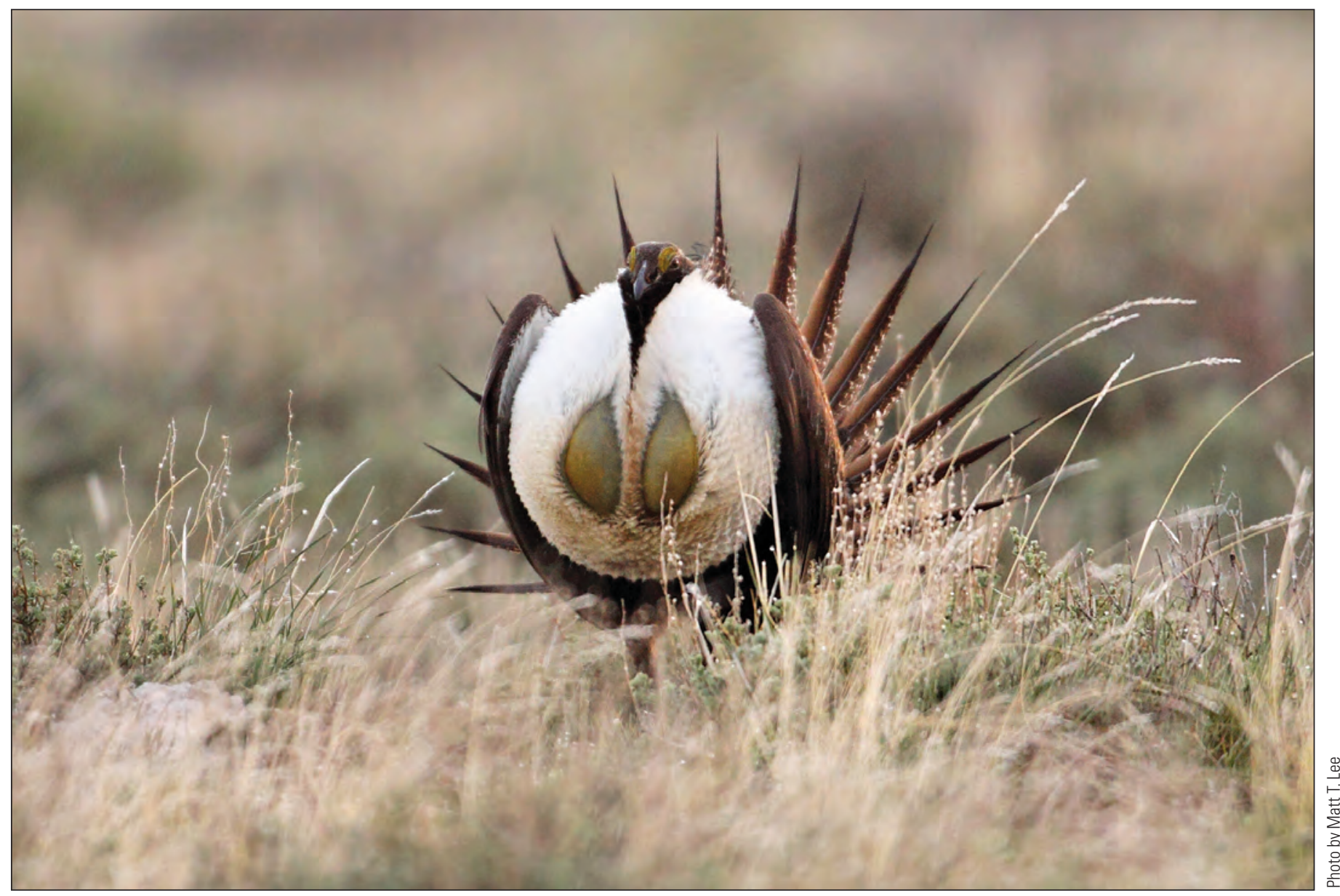

Greater sage-grouse. 


\section{Greater Sage-Grouse Responses to Climate Change and Future Energy Development in Wyoming}

It is expected that future oil and gas development and climate change will affect the landscape in southwestern Wyoming, but little is known about the potential magnitude of the effects on the greater sage-grouse population. USGS researchers and colleagues are using a spatially explicit, individual-based modeling approach to simulate direct and indirect responses of sage-grouse to future landscape changes in southwest Wyoming. Sage-grouse responses include modified habitat selection and behavioral responses forecasted using future scenarios of planned oil and gas development and climate-induced vegetation changes. The results of this study can help land managers assess the influence of management actions on future sage-grouse abundance, distribution, and trajectories, and aid in prioritizing future research and land-use planning.

Contact

Cameron Aldridge, USGS Fort Collins Science Center; aldridgec@usgs.gov; (970) 226-9433

\section{Investigating the Impacts of Oil and Gas Development on Greater Sage-Grouse by Using a Bayesian State-Space Model}

Global energy demand is expected to increase substantially in the next two decades, with fossil fuels accounting for more than one-third of that demand. The greater sage-grouse is a sagebrush-obligate species that has experienced population declines over the last several decades. These declines are attributed to a variety of disturbances including oil and gas development. To better understand how male sage-grouse lek, or breeding ground, attendance is affected by oil and gas development, the USGS and Colorado State University researchers are analyzing changes in male lek counts in Wyoming from 1984 to 2008. Disturbance due to oil and gas development was measured in addition to density and disturbance area, which accounted for well pad size and the spatial arrangement of well pads near a lek. This research can assist in the active management of sagebrush habitats, which may be necessary to maintain some sagebrush-obligate species despite current habitat protections.

Contact

Cameron Aldridge, USGS Fort Collins Science Center; aldridgec@usgs.gov; (970) 226-9433

\section{Conservation Buffer Distance Estimates for Greater Sage-Grouse-A Review}

The USGS published a report compiling and summarizing published scientific studies that evaluate the influence of anthropogenic activities and infrastructure on greater sage-grouse populations. The report provides a convenient reference for land managers and others who are working to develop biologically relevant and socioeconomically practical buffer distances around sage-grouse habitats. The summary addresses the potential effects of anthropogenic land use and disturbances on sage-grouse populations, provides ecologically based interpretations of evidence from the scientific literature, and informs implementation of conservation buffers around sage-grouse communal breeding locations known as leks.

Contacts

Peter S. Coates, USGS Western Ecological Research Center; pcoates@usgs.gov; (530) 669-5073

Michael Casazza, USGS Western Ecological Research Center; mike_casazza@usgs.gov; (530) 669-5075

\section{Publication}

Manier, D.J., Bowen, Z.H., Brooks, M.L., Casazza, M.L., Coates, P.S., Deibert, P.A., Hanser, S.E., and Johnson, D.H., 2014, Conservation buffer distance estimates for greater sage-grouse-A review: U.S. Geological Survey Open-File Report 2014-1239, http://dx.doi.org/ 10.3133/ofr20141239. 


\section{Birds in the Appalachians}

\section{Shale Gas Development Effects on Songbirds in Central Appalachia}

In the last decade, unconventional drilling for natural gas from the Marcellus-Utica shale formation has increased exponentially in the Central Appalachians. This heavily forested region contains important breeding habitat for many neotropical migratory songbirds, including several species of conservation concern. Research was conducted by the USGS to examine the effects of unconventional gas development on forest habitat and breeding songbirds at a predominantly forested site from 2008 to 2015. Results suggest that shale gas development has the potential to negatively impact forest ecosystems by reducing overall forest cover; however, forest fragmentation and reduction of core forest habitat are the greater potential impacts. This study may assist managers as they apply strategies for mitigation of negative impacts to sensitive species by leveraging the extensive horizontal reach of unconventional gas wells for site planning.

\section{Contact}

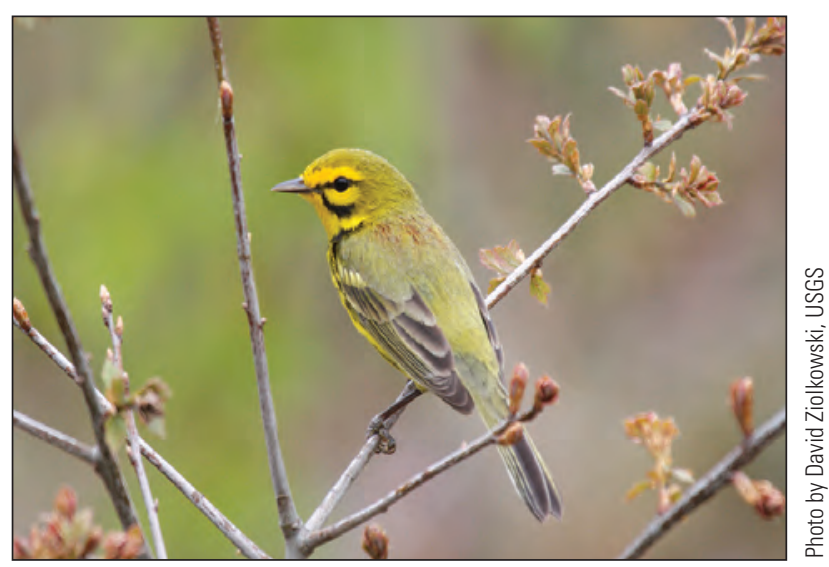

Prairie warbler (Setophaga discolor).

Petra Wood, USGS West Virginia Cooperative Fish and Wildlife Research Unit; pbwood@wvu.edu; (304) 293-5090

Publication

Farwell, L.S., Wood, P.B., Sheehan, James, and George, G.A., 2016, Shale gas development effects on the songbird community in a Central Appalachian forest: Biological Conservation, v. 201, p. 78-91, http://dx.doi.org/10.1016/j.biocon.2016.06.019.

\section{Bird Migration in the Central Appalachians}

During five bird-migration seasons, the USGS and collaborators studied nocturnal bird migration in the Central Appalachians of Maryland, Virginia, and West Virginia. Calls of migrating birds in flight were recorded to index the spatial and temporal distribution patterns of birds. Portable radar sampling was conducted concurrently with sound recording at some sites to corroborate the patterns observed and to provide information about the altitudinal distribution of migrants. In both spring and fall, nearly 30 percent of radar targets, representing birds or bats, were within 200 meters of the ground, the zone sampled by the sound recorders. Scientists are now using the flight call data to develop a model on the effects of weather, topography, and other variables on migrant abundance. This model will assist with the identification of where or when low-flying migrants are likely to be abundant. Maps of important stopover sites can be used to focus conservation efforts by preserving or enhancing patches of natural habitat, particularly deciduous forests, in developed or agricultural landscapes and along major coastlines.

\section{Contact}

Deanna Dawson, USGS Patuxent Wildlife Research Center; ddawson@usgs.gov; 301-497-5642

Publication

Buler, J.J., and Dawson, D.K., 2014, Radar analysis of fall bird migration stopover sites in the Northeastern U.S.: The Condor, v. 116, no. 3, p. 357-370, http://dx.doi.org/10.1650/condor-13-162.1.

\section{Reproductive Success and Habitat Use on Reclaimed Surface Mines}

Within the Appalachian region, an estimated 2,300 square miles of mature Appalachian forest were surface-mined and subsequently reclaimed to predominantly grassland habitats during 1978-2009. After mining, areas are reclaimed and planted with a mixture of grass and forb species, most of which are exotic. In a USGS study of three mountaintop mining-valley fill complexes in southwestern West Virginia, the grasshopper sparrow (Ammodramus savannarum) was the most common bird species observed on mine land reclaimed to grasslands. This study relates nesting habitat characteristics to nest success of grasshopper sparrows on the expansive reclaimed grasslands created on former mountaintop mining-valley fill mines within a heavily forested landscape. The study also examined whether post-reclamation age affected vegetation structure of grasslands and breeding success of grasshopper sparrows. This work provides information on possible active management actions that may be needed to support songbird habitat after mine reclamation.

Contact

Petra Wood, USGS West Virginia Cooperative Fish and Wildlife Research Unit; pbwood@wvu.edu; (304) 293-5090

\section{Publication}

Wood P.B., and Ammer, F.K., 2015, Grasshopper sparrow reproductive success and habitat use on reclaimed surface mines varies by age of reclamation: Wildlife Society Bulletin, v. 39, no. 3, p. 512-520, http://dx.doi.org/10.1002/wsb.563. 


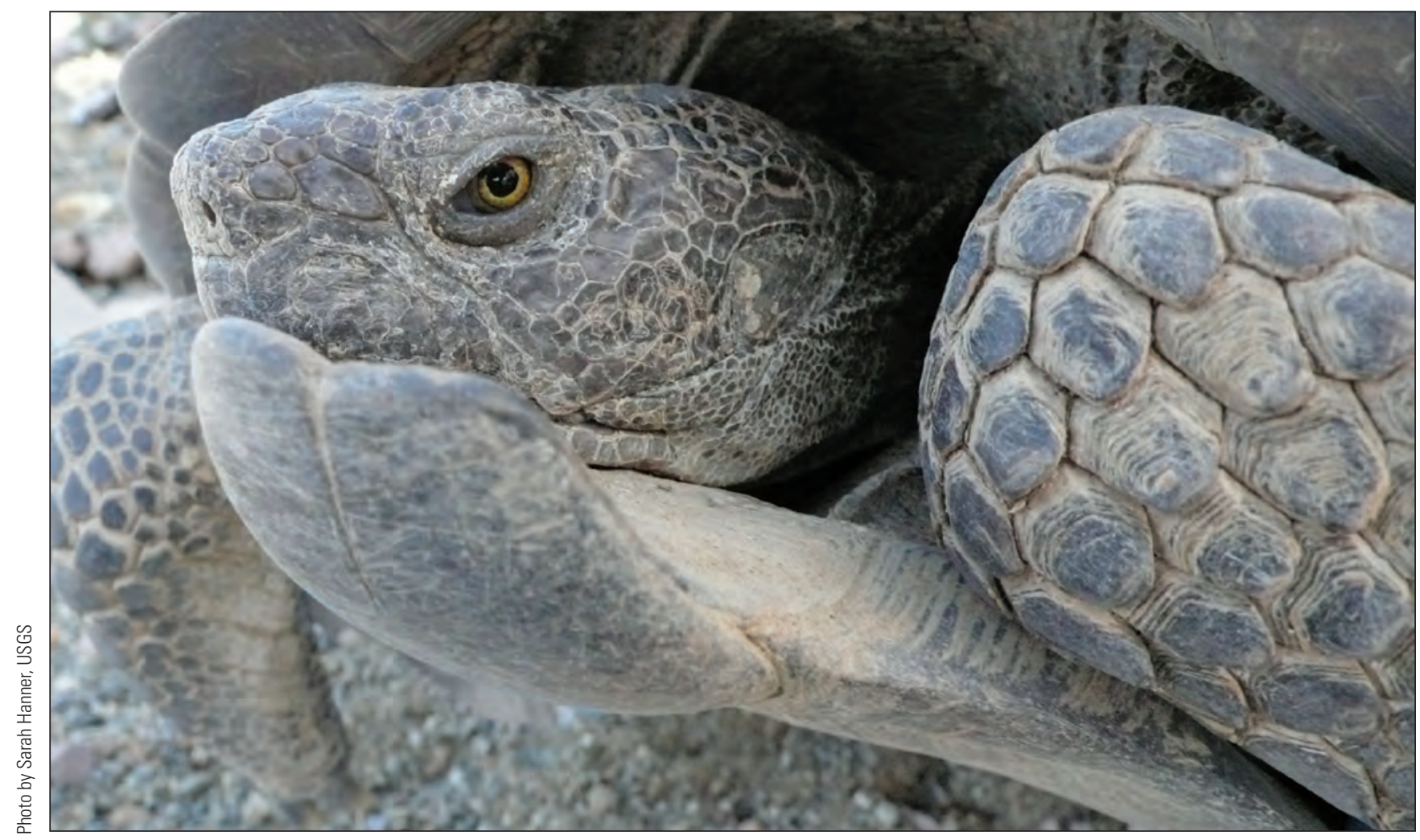

Adult male desert tortoise in central Mojave Desert, San Bernardino County, Calif.

\section{Desert Tortoises}

\section{Desert Tortoises and Wind Energy}

Since 1995, the USGS has studied the ecology of a population of federally protected Agassiz's desert tortoises (Gopherus agassizii) at a wind facility on land managed by the BLM near Palm Springs, California. To support recovery efforts for the species, almost 130 tortoises were marked between 1997 and 2000, providing a unique opportunity to examine the growth, demography, habitat selection, and survivorship of this long-lived species. Research continues and focuses on the effects of turbine-induced fire on the ecology and behavior of tortoises, genetic characteristics of the population, and the apparent lack of significant recruitment into the population.

Contact

Jeffrey Lovich, USGS Southwest Biological Science Center; jeffrey_lovich@usgs.gov; (928) 556-7358

\section{Publications}

Agha, Mickey, Delaney, David, Lovich, J.E., Briggs, Jessica, Austin, Meaghan, and Price, S.J., 2015, Nelson's big horn sheep (Ovis canadensis nelsoni) trample Agassiz's desert tortoise (Gopherus agassizii) burrow at a California wind energy facility: Bulletin of the Southern California Academy of Sciences, v. 114, no. 1, p. 58-62, http://dx.doi.org/10.3160/0038-3872-114.1.58.

Agha, Mickey, Lovich, J.E., Ennen, J.R., Augustine, Benjamin, Arundel, T.R., Murphy, M.O., Meyer-Wilkins, Kathie, Bjurlin, Curtis, Delaney, David, Briggs, Jessica, Austin, Meaghan, Madrak, S.V., and Price, S.J., 2015, Turbines and terrestrial vertebrates—Variation in tortoise survivorship between a wind energy facility and an adjacent undisturbed wildland area in the desert southwest (U.S.A.): Environmental Management, v. 56, no. 2, p. 332-341, http://dx.doi.org/10.1007/s00267-015-0498-9.

Lovich, J.E., 2015, Case study — Road proliferation due to rapid renewable energy development, in Andrews, K.A., Nanjappa, Priya, and Riley, S.P.D., eds., Roads and ecological infrastructure — Concepts and applications for small animals: Baltimore, Johns Hopkins UP and The Wildlife Society, p. 79-84.

Lovich, J.E., Agha, Mickey, Yackulic, C.B., Meyer-Wilkins, Kathie, Bjurlin, Curtis, Ennen, J.R., Arundel, T.R., and Austin, Meaghan, 2014, Nest site characteristics, nesting movements, and lack of long-term nest site fidelity in Agassiz's desert tortoises at a wind energy facility in southern California: California Fish and Game, v. 100, no. 3, p. 404-416.

Lovich, J.E., Delaney, David, Briggs, Jessica, Agha, Mickey, Austin, Meaghan, and Reese, Jason, 2014, Black bears (Ursus americanus) as a novel potential predator of Agassiz's desert tortoises (Gopherus agassizii) at a California wind energy facility: Bulletin of the Southern California Academy of Sciences, v. 113, no. 1, p. 34-41, http://dx.doi.org/10.3160/0038-3872-113.1.34. 


\section{Effects of Solar Development and Habitat Alterations on Desert Tortoises in the Ivanpah Valley}

The Ivanpah Valley in southeastern California and southern Nevada is a hotspot of genetic diversity and connectivity for Agassiz's desert tortoise that overlaps with utility-scale solar development. The USGS, the University of Nevada at Reno, and partners are developing and applying novel tracking, genetic tagging, and biomarkers for assessing movement, health, and population connectivity in the valley relative to landscape features and renewable energy development that promote or impede population connectivity.

\section{Contacts}

Todd Esque, USGS Western Ecological Research Center; tesque@usgs.gov; (702) 564-4506

Amy Vandergast, USGS Western Ecological Research Center; avandergast@usgs.gov; (619) 225-6445

Publication

Bowen, Lizabeth, Miles, A.K., Drake, K.K., Waters, S.C., Esque, T.C., and Nussear, K.E., 2015, Integrating gene transcription-based biomarkers to understand desert tortoise and ecosystem health: Ecohealth, v. 12, no. 3, p. 501-512, http://dx.doi.org/10.1007/s10393-014-0998-8.

\section{Desert Tortoise Annotated Bibliography}

Agassiz's desert tortoise is a State- and federally listed threatened species. The USGS compiled and published an annotated bibliography of peer-reviewed journal articles published between January 1991 and December 2015 on Agassiz's desert tortoise. The purpose of this annotated bibliography is to support recovery efforts for the species' critical habitats. Populations have continued to decline in spite of critical habitat designations. The bibliography also includes articles concerning anthropogenic impacts to desert tortoises and the habitats they occupy.

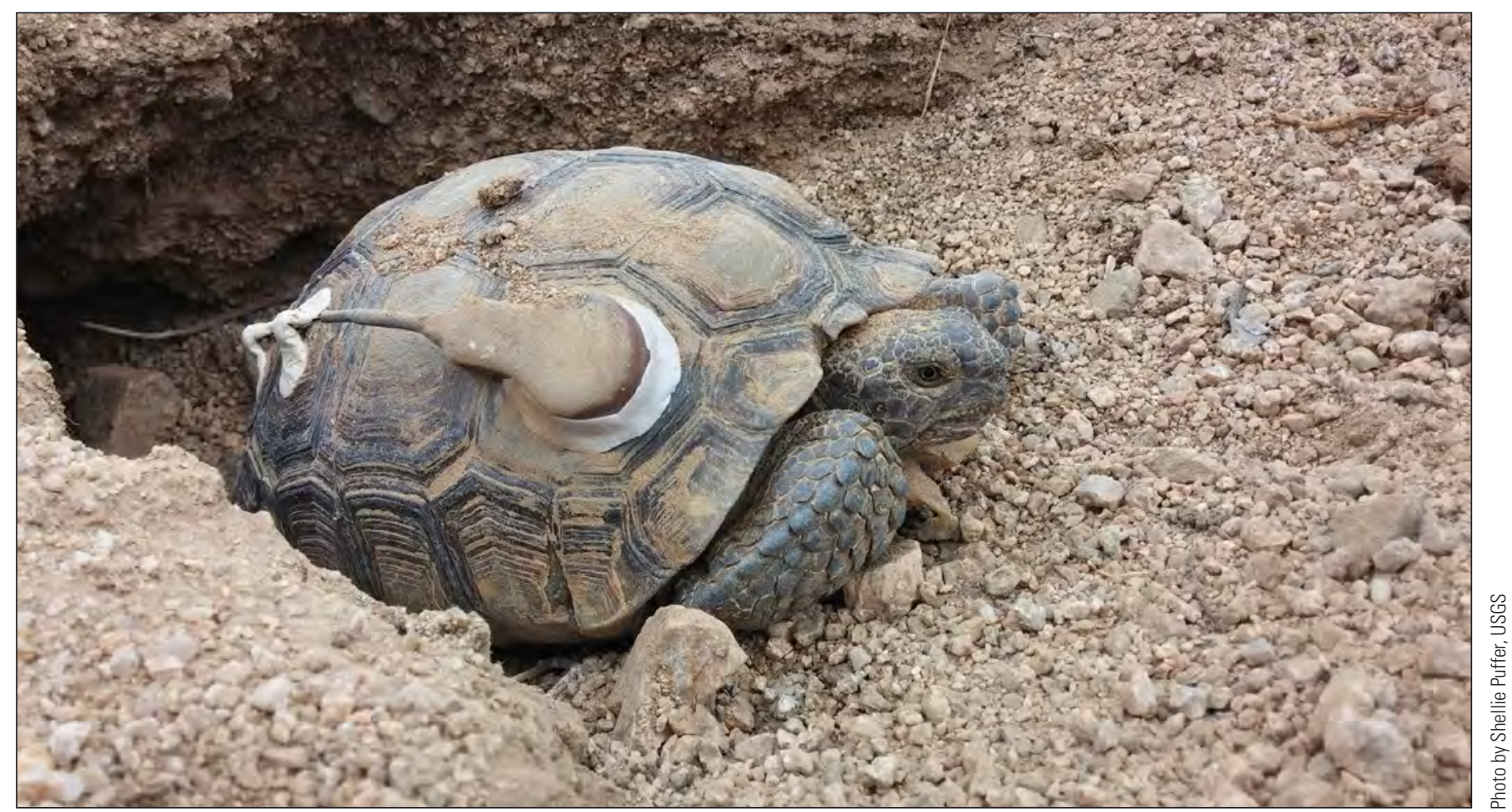

A female Agassiz's desert tortoise, wearing a USGS radio, lounges in the entrance of her burrow at Joshua Tree National Park.

\section{Contact}

Kristin Berry, USGS Western Ecological Research Center; kristin_berry@usgs.gov; (951) 697-5361

\section{Publication}

Berry, K.H., Lyren, L.M., Mack, J.S., Brand, L.A., and Wood, D.A., 2016, Desert tortoise annotated bibliography, 1991-2015: U.S. Geological Survey Open-File Report 2016-1023, 312 p., http://dx.doi.org/10.3133/ofr20161023. 


\section{Pollinators}

\section{Impact of Biofuel Crop Production on Pollinators in the Northern Great Plains}

The USGS, in cooperation with the U.S. Department of Agriculture (USDA), is quantifying how recent reductions in USDA conservation program enrollments affect pollinator habitat. Researchers are also developing a risk assessment model to identify what portions of the Northern Great Plains have undergone the most substantial land-use changes due to biofuel crop development while also supporting the highest density of commercial beekeepers. This study addresses several of the key information needs proposed in President Barak Obama's Federal Strategy for Pollinator Conservation to better understand, minimize, and recover from pollinator losses.

\section{Contact}

Clint Otto, USGS Northern Prairie Wildlife Research Center; cotto@usgs.gov; (701) 253-5563

\section{Publication}

Otto C.R., Roth C.L., Carlson B.L., and M.D. Smart, in press, Land-use change reduces habitat suitability for supporting managed honey bee colonies in the Northern Great Plains: Proceedings of the National Academy of Sciences, v. 113, http://dx.doi.org/10.1073/pnas.1603481113.

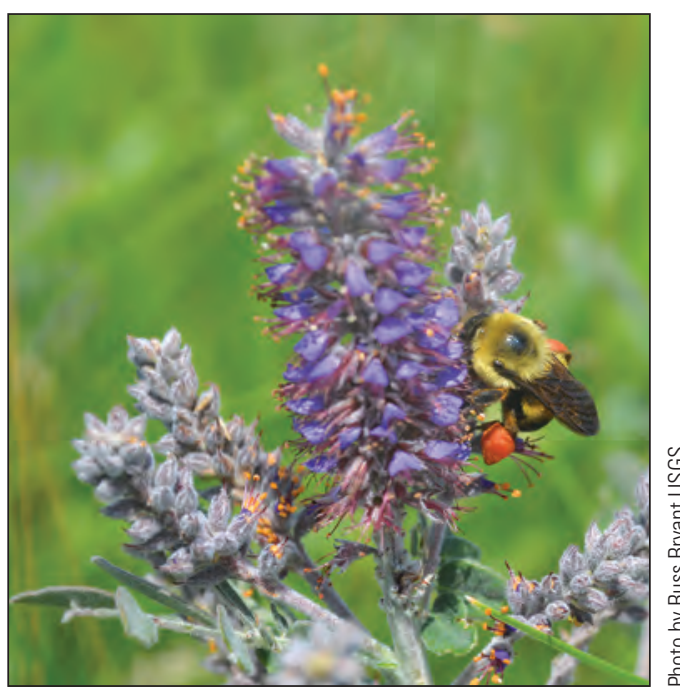

Amorpha canescens with Bombus griseocollis.

[Project overview video: https://www.youtube.com/watch?v=3_O6RDdrfDc].

\section{Taxonomic Characterization of Honey Bee Pollen Foraging}

USGS scientists recently developed a genetic sequencing technique to identify pollen collected by foraging bees. The USGS is currently applying this technique to understand how land-use change and biofuel crop development affect forage for pollinators in agro-ecosystems. Together, this information can be used to evaluate specific plants that can be used in restoration programs for pollinators.

\section{Contact}

Clint Otto, USGS Northern Prairie Wildlife Research

Center; cotto@usgs.gov; (701) 253-5563

\section{Publication}

Cornman, R.S., Otto, C.R.V., Iwanowicz, Deborah, and Pettis, J.S., 2015, Taxonomic characterization of honey bee (Apis mellifera) pollen foraging based on non-overlapping paired-end sequencing of nuclear ribosomal loci: PLOS ONE, v. 10, no. 12, e0145365, http://dx.doi.org/10.1371/journal.pone.0145365.

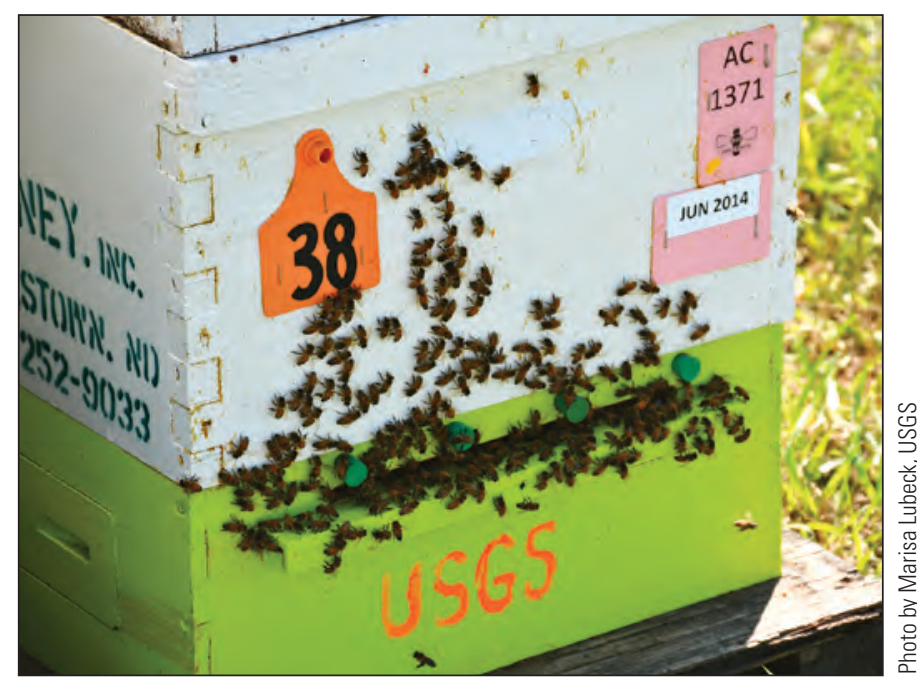

The USGS Northern Prairie Wildlife Research Center partners with professional beekeepers in North Dakota to evaluate what plant species honey bees forage and when.

\section{Designing Conservation Seeding Mixes}

USGS scientists are working closely with the USDA to quantify the benefits of USDA conservation lands for supporting healthy pollinator populations in the Northern Great Plains. In response to this need, the USGS developed a tool for land managers to assist with conservation seeding mix design for land enhancement programs. This tool will be useful for restoring habitat for pollinators in areas where marginally productive lands are retired from biofuel crop production.

Contact

Clint Otto, USGS Northern Prairie Wildlife Research Center; cotto@usgs.gov; (701) 253-5563 


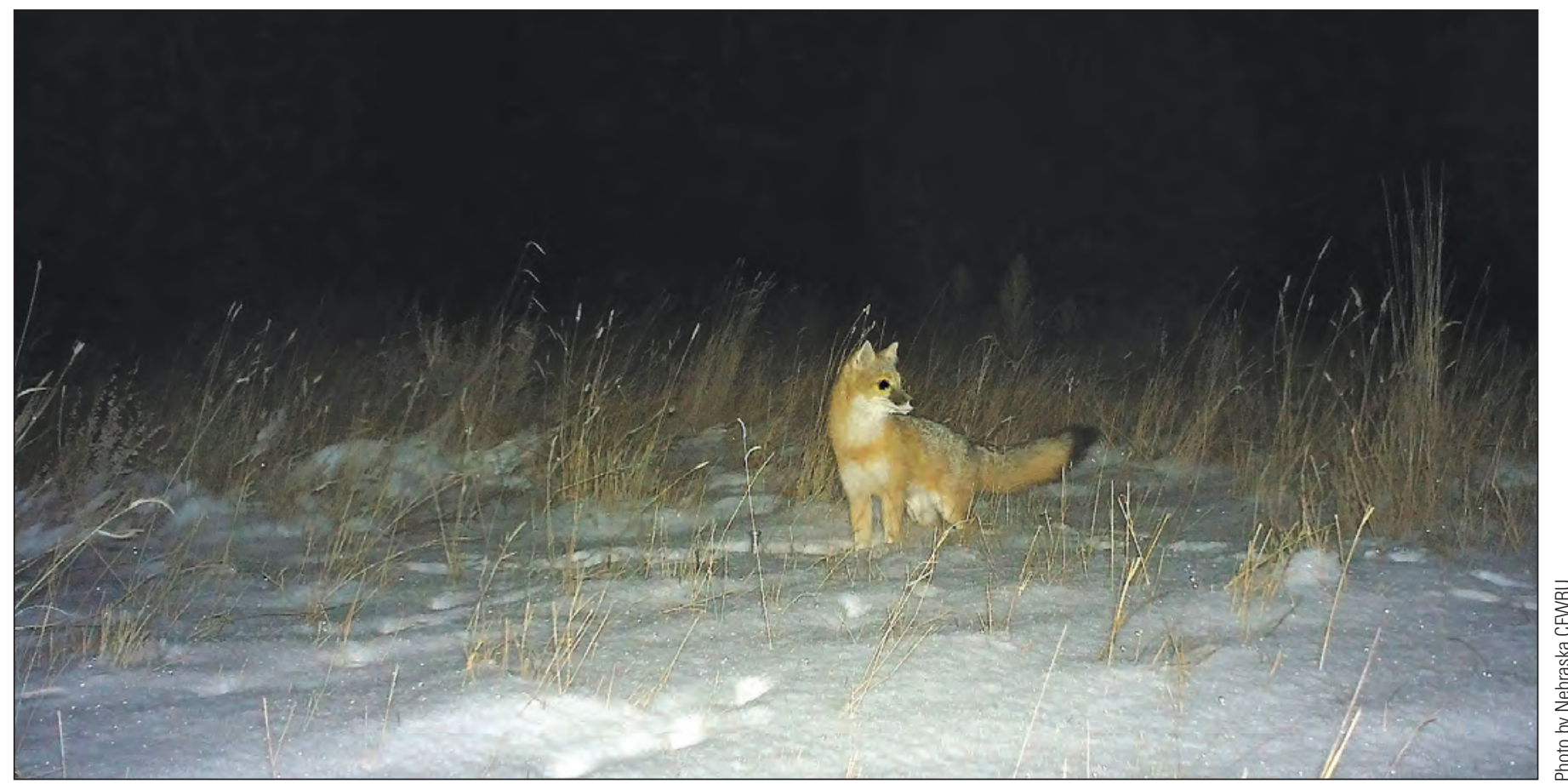

Swift fox captured by a trail camera in western Nebraska.

\section{Other Species}

\section{Canid Distribution and the Potential Impacts of Energy Development in Nebraska}

The USGS, in collaboration with the Nebraska Game and Parks Commission, the Nebraska Department of Roads, the Nebraska Environmental Trust, the U.S. Forest Service, Chadron State College, and the University of Nebraska, is implementing a comprehensive survey and monitoring plan for swift fox across 26,000 square miles of western Nebraska. The goal of the Nebraska Canid Project is to document the current distribution and ecological requirements of swift fox (Vulpes velox) and explore how infrastructure development may alter future habitat conditions and subsequently Nebraska's canid communities by creating and testing a series of predictive species distribution models. The resulting models will be packaged into a decisionsupport tool to assist policy makers and management agencies in future energy siting decisions.

Contact

Joseph J. Fontaine, USGS Nebraska Cooperative Fish and Wildlife Research Unit; jfontaine2@unl.edu; (402) 472-0339

\section{Quantifying Exposure of Wildlife to Oil, Gas, and Wind Energy Development}

USGS researchers estimated exposure of a wide range of sensitive species in Wyoming on the basis of the extent of their potential distribution overlapping with current and projected energy development, including wind and oil and gas production. Researchers also estimated development exposure for each of 156 species of greatest conservation need found in Wyoming. Results show that exposure of Wyoming's sensitive species to wind turbines will be far less than to petroleum infrastructure, but petroleum and wind energy footprints are largely non-overlapping and result in spatially extensive disturbance from the combination of the two types of energy development. Findings from this study have been used to clarify research, monitoring, and management priorities for State and Federal wildlife managers in Wyoming.

\section{Contact}

Matthew Kauffman, USGS Wyoming Cooperative Fish and Wildlife Research Unit; mkauffm1@uwyo.edu; 307-766-6404

\section{Publication}

Keinath, Douglas, and Kauffman, Matthew, 2014, Quantifying exposure of Wyoming's wildlife to energy development in the face of expanding production: Cheyenne, Wyo., Wyoming Game and Fish Department, and Fort Collins, Colo., U.S. Geological Survey, 65 p., http://www.uwyo.edu/wyndd/_files/docs/reports/wynddreports/u14kei01wyus.pdf. 


\section{Land Use and Microhabitat Effects on Salamanders in the Central Appalachian Coal Fields}

The USGS, along with Virginia Polytechnic Institute and State University, is investigating the utility of using aquatic salamander surveys as a surrogate for costly and complex macroinvertebrate surveys to assess post-mining stream recovery and health in the Central Appalachian coalfields. Some salamander species are identified as tolerant to stream habitat and water-quality degradation while others are only found in streams with high biological integrity. These characteristics allow for a quicker, more cost effective way for researchers and managers to score aquatic health and determine watershed status. Scientists are also examining connections between spatial and land-use data with both salamanders and macroinvertebrates that may result in the development of a stronger watershed assessment tool using spatial imagery matched with water-quality parameters, such as conductivity and total dissolved solids, for large portions of the Central Appalachian coalfields.

\section{Contact}

Mark Ford, USGS Virginia Cooperative Fish and Wildlife Research Unit; wmford@vt.edu; (540) 231-5927

\section{Publications}

Sweeten, S.E., and Ford, W.M., 2016, Effects of microhabitat and large-scale land use on stream salamander occupancy in the coalfields of Central Appalachia: Journal of Ecology and the Natural Environment, v. 8, no. 9, p. 129-141, http://dx.doi.org/10.5897/JENE2016.0564.

Sweeten, S.E., and Ford, W.M., 2016, Validation of a stream and riparian habitat assessment protocol using stream salamanders in the southwest Virginia coalfields: Journal of American Society of Mining and Reclamation, v. 5, no. 1, p. 45-66, http://dx.doi.org/10.21000/ jasmr16010045.

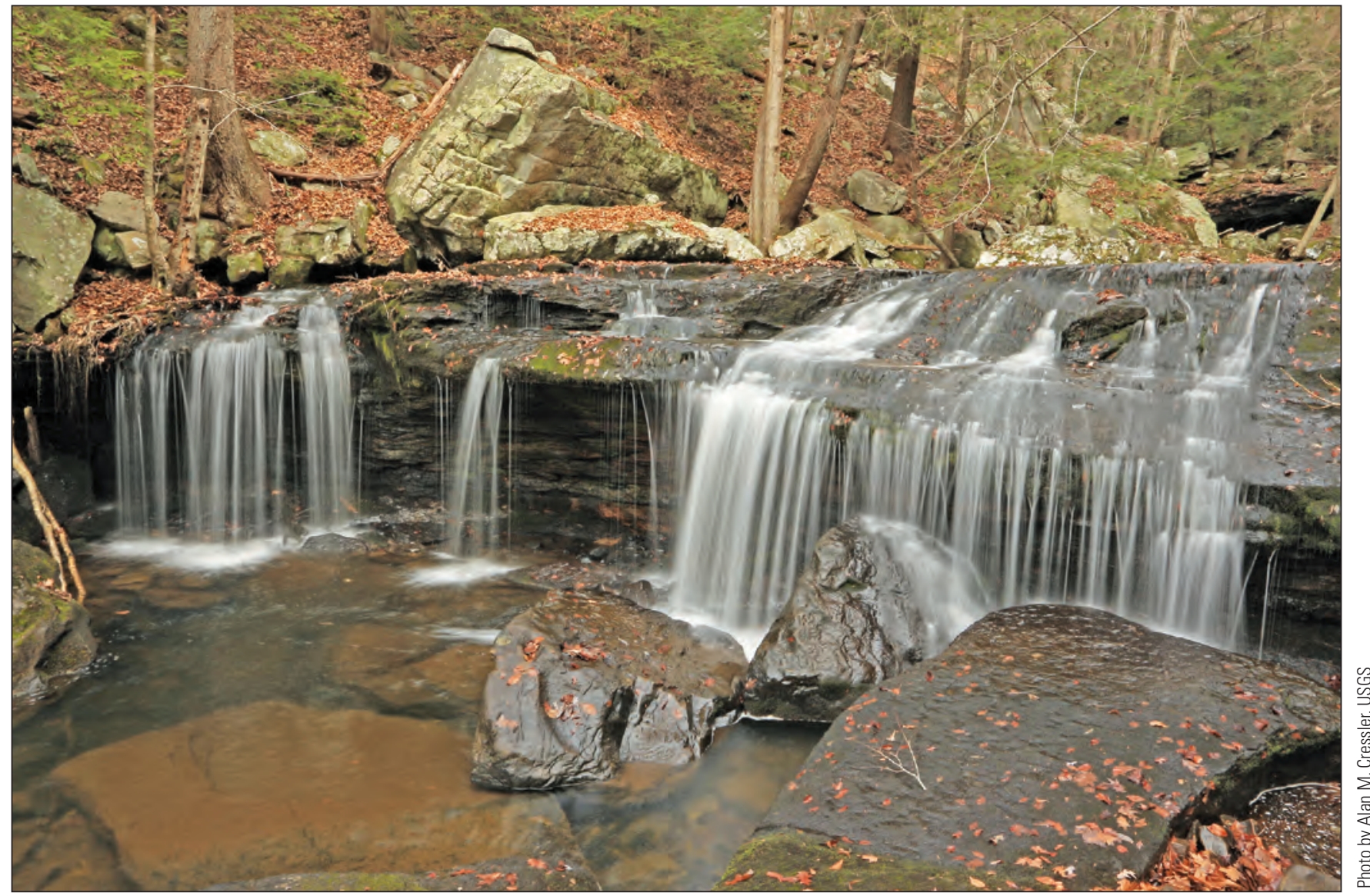

Lower Coal Mine Falls, South Cumberland State Recreation Area, Marion County, Tenn. 


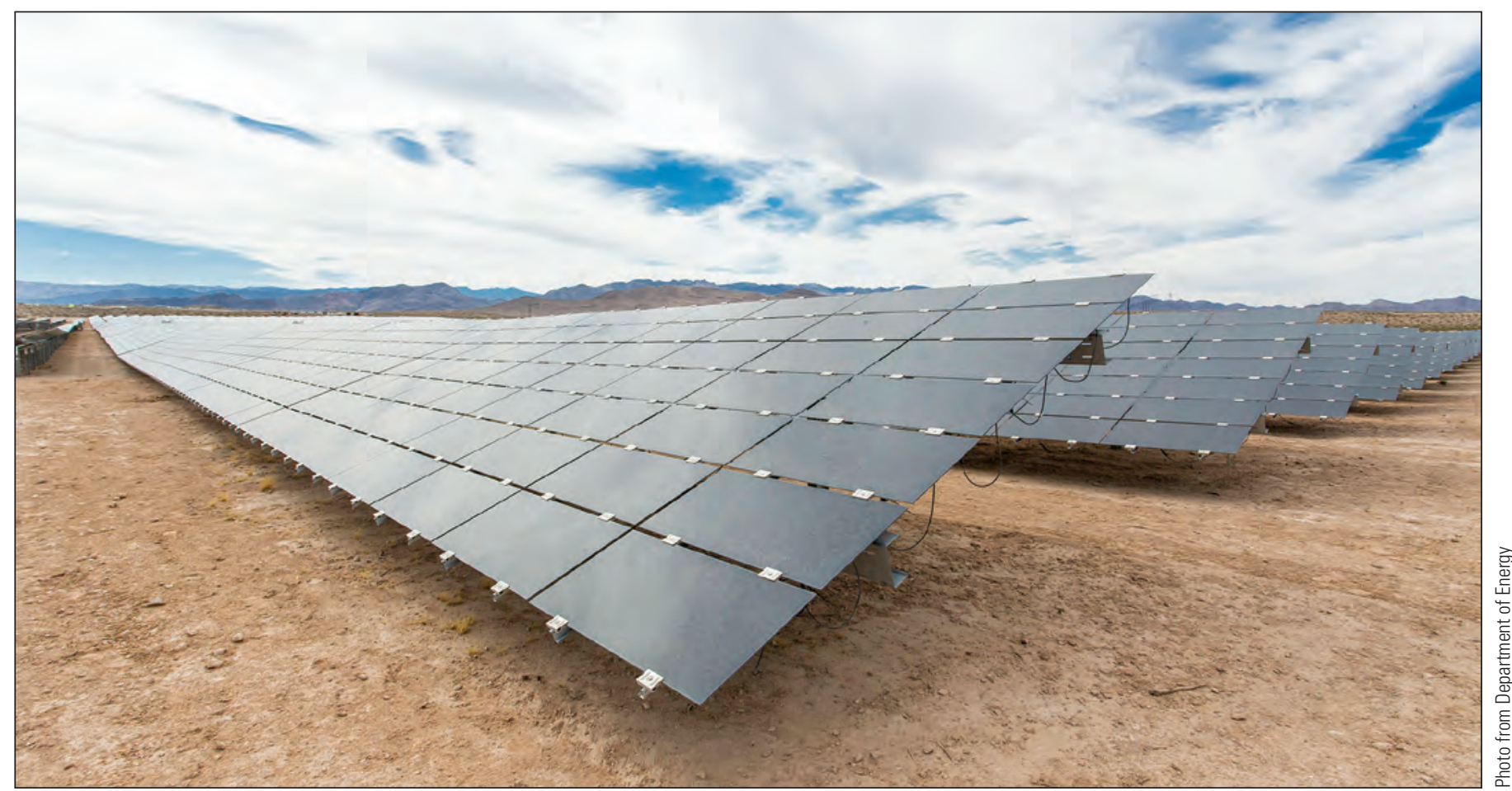

Utility-scale solar array on Moapa Band of Paiutes Indian land, Nevada.

\section{Utility-Scale Solar Energy}

\section{Efficacy of Wildlife Monitoring Technologies at a Solar Tower Facility}

Little is known about the effects of solar power towers on flying animals and few methods exist for automatically detecting or observing wildlife at solar towers and other tall anthropogenic structures. The USGS evaluated the potential effectiveness of electro-optical and thermal video cameras, radar, and invertebrate sampling equipment to observe and monitor birds, bats, and insects flying in the vicinity of solar flux fields produced at the Ivanpah Solar Electric Generating System facility in southern California. Video observations suggest that most flying animals affected by solar flux were insects, although some birds were also affected. Technologies examined show promise for developing a camera-based real-time system for monitoring flying animals entering solar flux fields.

\section{Contact}

Robb Diehl, USGS Northern Rocky Mountain Science Center; rhdiehl@usgs.gov; (406) 994-7481

\section{Publication}

Diehl, R.H., Valdez, E.W., Preston, T.M., Wellik, M.J., and Cryan, P.M., 2016, Evaluating the effectiveness of wildlife detection and observation technologies at a solar power tower facility: PLOS ONE, v. 11, no. 7, e0158115, http://dx.doi.org/10.1371/journal.pone.0158115.

\section{Fatality Monitoring Design for Utility-Scale Solar Power Facilities}

Understanding how wildlife are affected by solar power development is a priority for the USFWS. Previous research has focused on the effects of wind energy development on wildlife; however, guidance for addressing solar development effects on wildlife, including a methodological assessment to accurately estimate mortality, is lacking. In a new USGS report, researchers suggest methods for monitoring mortality at solar facilities on the basis of current wind-power facilities procedures adapted for unique conditions encountered at solar facilities. Researchers present case studies to illustrate how distance-sampling techniques may improve overall detectability without substantially increasing monitoring costs. By addressing spatial variation in causes of mortality, as well as potential sources of imperfect detection, researchers provide information to help guide design of monitoring programs to estimate bird and bat fatalities occurring at a facility over an extended period of time.

Contact

Manuela Huso, USGS Forest and Rangeland Ecosystem Science Center; mhuso@usgs.gov; (541) 750-0948 


\section{Publication}

Huso, Manuela, Dietsch, Thomas, and Nicolai, Chris, 2016, Mortality monitoring design for utility-scale solar power facilities: U.S. Geological Survey Open-File Report 2016-1087, 44 p., http://dx.doi.org/10.3133/ofr20161087.

\section{Climate Change, Conservation Planning, and Renewable Energy Development in the Mojave Desert}

USGS scientists completed a multiyear project to develop analytical approaches, tools, and geospatial data to support conservation planning for renewable energy development in the California deserts. Research focused on geographical analysis to avoid, minimize, and mitigate the cumulative biological effects of utility-scale solar energy development. Researchers collected new data and created new methods to model cumulative impacts for conservation planning applications. A model was created to map the relative degree of compatibility of new solar energy projects with current biological conservation values. Species distribution models were produced

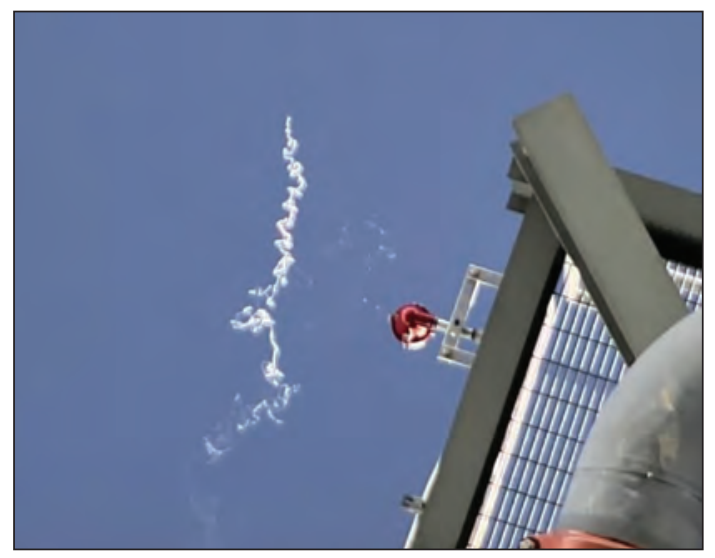

Erratic flight of insect burning in a solar flux field produced by a solar tower facility in the Mojave Desert, Calif. (from Diehl and others, 2016).

for 65 animal and plant species of potential conservation importance to the DRECP process. These models were used to map both historical and projected future habitat. A spatial decision support tool was created to aid in locating potential sites for offsetting project impacts based on user-supplied conservation criteria. Finally, an analytical framework was designed to assess the potential cumulative impacts of multiple solar energy projects given background climate and land-use change.

\section{Contact}

Jason Kreitler, USGS Western Geographic Science Center; jkreitler@usgs.gov; (208) 426-5217

\section{Publication}

Kreitler, Jason, Schloss, C.A., Soong, Oliver, Hannah, Lee, and Davis, F.W., 2015, Conservation planning for offsetting the impacts of development—A case study of biodiversity and renewable energy in the Mojave Desert: PLOS ONE, v. 10, no. 11, e0140226, http://dx.doi.org/10.1371/journal.pone.0140226.

\section{Solar-Facility Fatality Estimator and Evidence of Absence Software}

Solar energy development can present several different sources of fatality to wildlife, especially birds. Estimates of fatality must combine fatalities from each of the various sources to accurately estimate total birds killed for an entire facility. USGS scientists are responding to a need for consistent and accurate methods to detect and estimate fatalities from carcass searches at solar facilities. Research will modify existing mortality estimation to produce unbiased estimates of fatalities and develop "evidence of absence" software for rare species at solar facilities. The approach will account for searcher efficiency and carcass persistence as well as different sources of fatality at solar facilities. The research will assist the USFWS and the BLM, on whose lands much solar development is taking place, to analyze data on the effects of solar facilities on migratory bird mortality and on potential impacts to protected species.

Contact

Manuela Huso, USGS Forest and Rangeland Ecosystem Science Center; mhuso@usgs.gov; (541) 750-0948

\section{Developing a West-Wide Listing of Solar Facilities}

The USGS is developing a map for the BLM for the Western United States that includes estimates of the surface disturbance footprint of solar facilities. As part of this effort, the USGS is digitizing existing utility-scale solar facility boundaries and creating geospatial datasets of these boundaries located within 17 Western States. Readily available, high-resolution true-color aerial photographs will be used to define boundaries of solar powerplants. The data are collected at a scale range between 1:1,000 and 1:5,000. This data series contributes to an Online Interactive Energy Atlas which synthesizes data on existing and potential energy development and includes additional natural resource data layers. This information can be used by decisionmakers to evaluate and compare the potential benefits and tradeoffs associated with different energy development strategies or scenarios.

\section{Contact}

Tasha Carr, USGS Fort Collins Science Center; carrn@usgs.gov; (970) 226-9446

\section{Publication}

Ignizio, D.A., and Carr, N.B., 2012, Locations and attributes of utility-scale solar power facilities in Colorado and New Mexico, 2011:

U.S. Geological Survey Data Series 693, http://pubs.usgs.gov/ds/693/. 


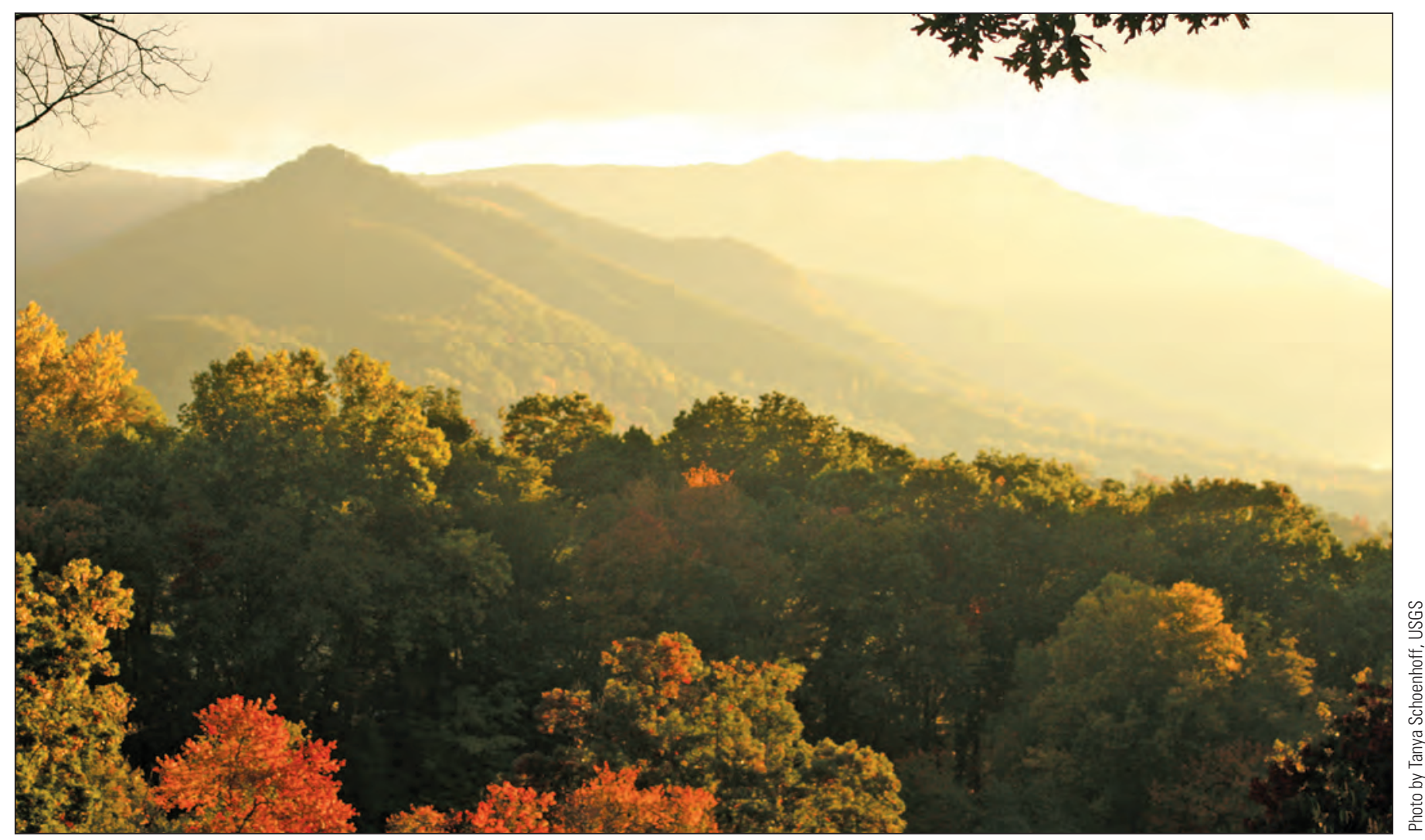

Evening sunset over the mountains in Waynesville, N.C.

\section{Bioenergy}

\section{Bioenergy Production and Landscape Change in the Southeastern United States}

Production of woody biomass for bioenergy has the potential to cause substantial landscape change and related effects on forest ecosystems, yet the landscape effects of alternative production scenarios have not been fully assessed. In a recent study, USGS researchers simulated landscape change from 2010 to 2050 under five scenarios of woody biomass production for wood pellets and liquid biofuels in North Carolina, a region that is a substantial producer of wood biomass for bioenergy and contains high biodiversity. Another USGS study used a forest economics model, spatially explicit state-and-transition simulation models, and species-habitat models to project change in habitat amount for 16 wildlife species from reaching a renewable fuel target and expected demand for wood pellets in North Carolina. These studies show bioenergy feedstock portfolio decisions may affect landscape-scale impacts on wildlife habitat among species.

\section{Contacts}

Jaime Collazo, USGS North Carolina Cooperative Fish and Wildlife Research Unit; Jaime_collazo@ncsu.edu; (919) 515-8837 Nathan Tarr, USGS North Carolina Cooperative Fish and Wildlife Research Unit; nmtarr@ncsu.edu; (919) 513-7280

\section{Publications}

Costanza, G.K., Abt, R.C., McKerrow, A.J., and Collazo, J.A., 2016, Bioenergy production and forest landscape change in the Southeastern United States: GCB Bioenergy, unpaginated, http://dx.doi.org/10.1111/gcbb.12386.

Tarr, N.M., Rubino, M.J., Costanza, J.K., McKerrow, A.J., Collazo, J.A., and Abt, R.C., 2016, Projected gains and losses of wildlife habitat from bioenergy-induced landscape change: GCB Bioenergy, unpaginated, http://dx.doi.org/10.1111/gcbb.12383. 


\section{Potential Impacts of Switchgrass Production on Grassland Birds}

Switchgrass (Panicum virgatum) is an alternative bioenergy species being promoted for large-scale cellulosic ethanol production in the Great Plains. To explore the potential impacts of switchgrass production on grassland birds, USGS researchers developed four agricultural land-use change scenarios for an intensively cultivated landscape, each driven by potential future climatic changes and ensuing irrigation limitations, ethanol demand, commodity prices, and continuation of a conservation program. For each scenario, the study calculated changes in area for land-cover classes and predicted changes in grassland bird abundances. This research provides information that managers can use to inform future land use decisions for bioenergy production.

Contact

Craig Allen, USGS Nebraska Cooperative Fish and Wildlife Research Unit; allencr@usgs.gov; (402) 472-0449

Publication

Uden, D.R., Allen, C.R., Mitchell, R.B., McCoy, T.D., and Guan, Qingfeng, 2014, Predicted avian responses to bioenergy development scenarios in an intensive agricultural landscape: GCB Bioenergy, v. 7, no. 4, p. 717-726, http://dx.doi.org/10.1111/gcbb.12157.

\section{Potential for Agave Biofuel Production}

The USGS is collaborating with the USDA Arid Land Agricultural Research Center and Ohio University regarding the potential for agave biofuel production to add to our national bioenergy portfolio in marginally productive lands. Agave may represent a highly efficient biofuel, even under nonirrigation conditions, but the ecosystem consequences of this development on drylands, including habitat and wildlife, remains unknown. The project aims to explore the potential benefits and drawbacks of this alternative energy source and strategy.

\section{Contact}

Sasha Reed, USGS Southwest Biological Science Center; screed@usgs.gov; (435) 210-4824

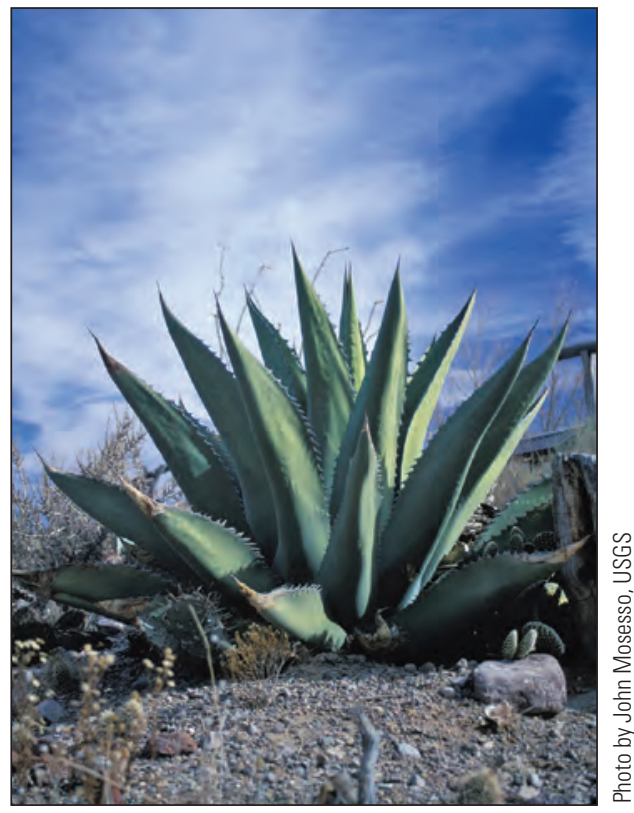

American agave (Agave americana) plant in New Mexico. 


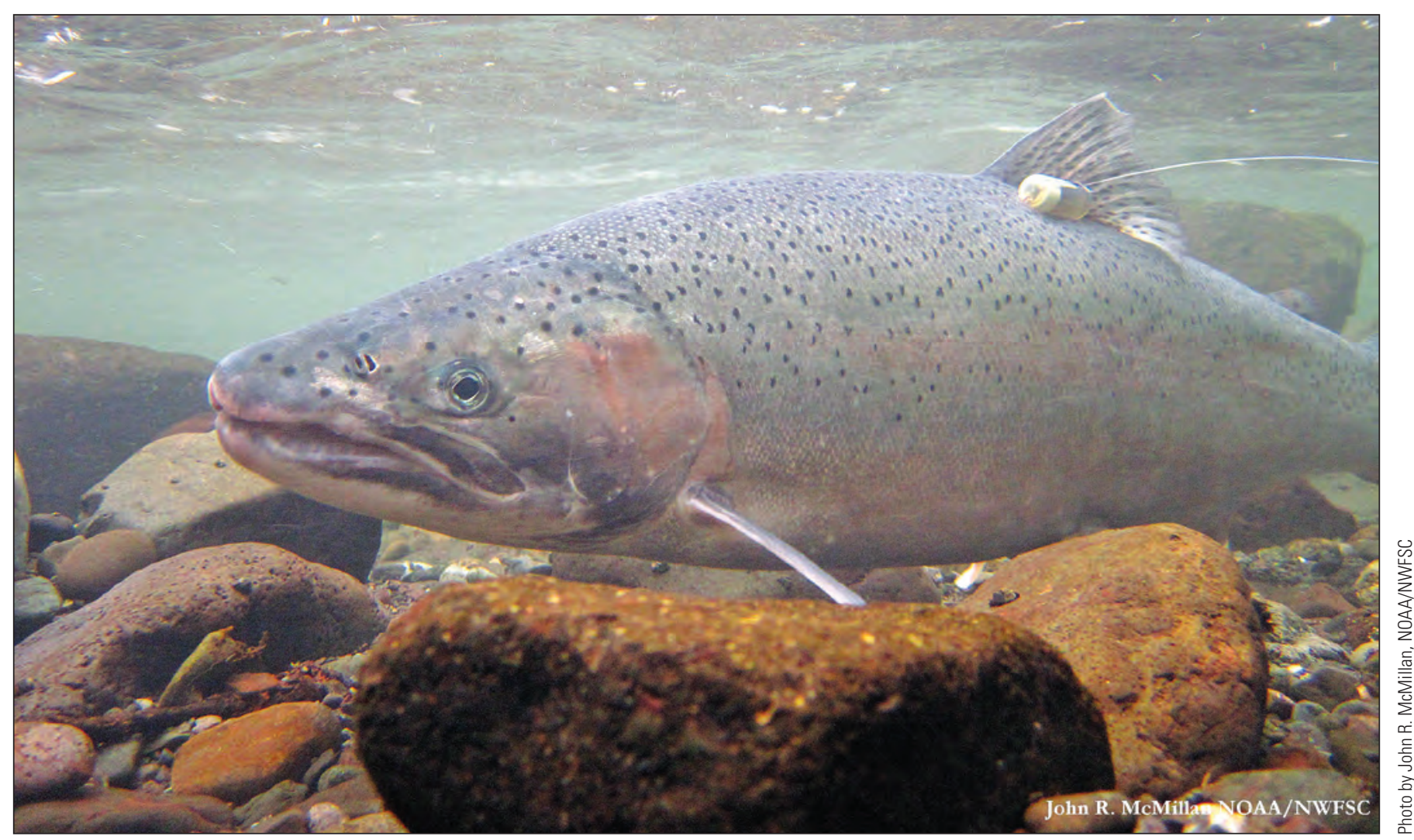

Steelhead (Oncorhynchus mykiss) salmon.

\section{Hydropower}

\section{Fish Passage and Survival Through Diversion Dams}

Diversion dams can negatively affect emigrating juvenile salmon populations because fish must pass through the impounded river created by the dam, negotiate a passage route at the dam, and emigrate through a riverine reach that has been affected by reduced river discharge. To quantify the effects of a main-stem diversion dam on juvenile Chinook salmon (Oncorhynchus tshawytscha), USGS scientists used radio telemetry to understand how dam operations and river discharge downstream from the dam affected route-specific passage and survival.

\section{Contact}

Russell Perry, USGS Western Fisheries Research Center; rperry@usgs.gov; (509) 538-2299

\section{Publication}

Perry, R.W., Kock, T.J., Courter, T.M., Garrison, T.M., Hubble, J.D., and Child, D.B., 2014, Dam operations affect route-specific passage and survival of juvenile Chinook salmon at a main-stem diversion dam: River Research and Applications, unpaginated, http://dx.doi.org/ 10.1002/rra.3059.

\section{Hydropower Effects on River Food Webs}

A majority of river systems in the Western United States have been altered by the construction of hydroelectric dams that have created impoundments upstream and greatly altered the natural flow patterns downstream. USGS researchers developed a life history-hydrodynamic model to look at the effects of downstream regulated flow regimes on aquatic insect populations. Aquatic insects are a cornerstone of river food webs and can be a key indicator to the effects of altered flow regimes on the larger ecological river system. Modeled results show that flow regimes favoring hydroelectric-power generation create a scenario where many aquatic insects are eliminated from downstream habitats.

\section{Contact}

Theodore Kennedy, USGS Southwest Biological Science Center; tkennedy@usgs.gov; (928) 556-7374 


\section{Publication}

Kennedy, T.A., Muehlbauer, J.D., Yackulic, C.B., Lytle, D.A., Miller, S.W., Dibble, K.L., Kortenhoven, E.W., Metcalfe, A.N., and Baxter, C.V., 2016, Flow management for hydropower extirpates aquatic insects, undermining river food webs: BioScience, v. 66, no. 7, p. 561-575, http://dx.doi.org/10.1093/biosci/biw059.

\section{Structured Decisionmaking for the Management of Glen Canyon Dam}

The USGS, in cooperation with the Bureau of Reclamation (BOR), National Park Service (NPS), and Argonne National Laboratory, provided an analysis of long-term management of water releases from Glen Canyon Dam in northern Arizona and associated management activities. This information may be used by the BOR and NPS in their evaluation of management alternatives for the Glen Canyon Dam Environmental Impact Statement. Two primary decision analysis methods - multi-criteria decision analysis and the expected value of information - were used to evaluate resource goals and influence of uncertainty by the various alternative plans.

\section{Contact}

Michael Runge, USGS Patuxent Wildlife Research Center; mrunge@usgs.gov; (301) 497-5748

\section{Publication}

Runge, M.C., LaGory, K.E., Russell, Kendra, Balsom, J.R., Butler, R.A., Coggins, L.G., Jr., Grantz, K.A., Hayse, John, Hlohowskyj, Ihor, Korman, Josh, May, J.E., O'Rourke, D.J., Poch, L.A., Prairie, J.R., VanKuiken, J.C., Van Lonkhuyzen, R.A., Varyu, D.R., Verhaaren, B.T., Vesekla, T.D., Williams, N.T., Wuthrich, K.K., Yackulic, C.B., Billerbeck, R.P., and Knowles, G.W., 2015, Decision analysis to support development of the Glen Canyon Dam Long-Term Experimental and Management Plan: U.S. Geological Survey Scientific Investigations Report 2015-5176, 64 p., http://dx.doi.org/10.3133/sir20155176.

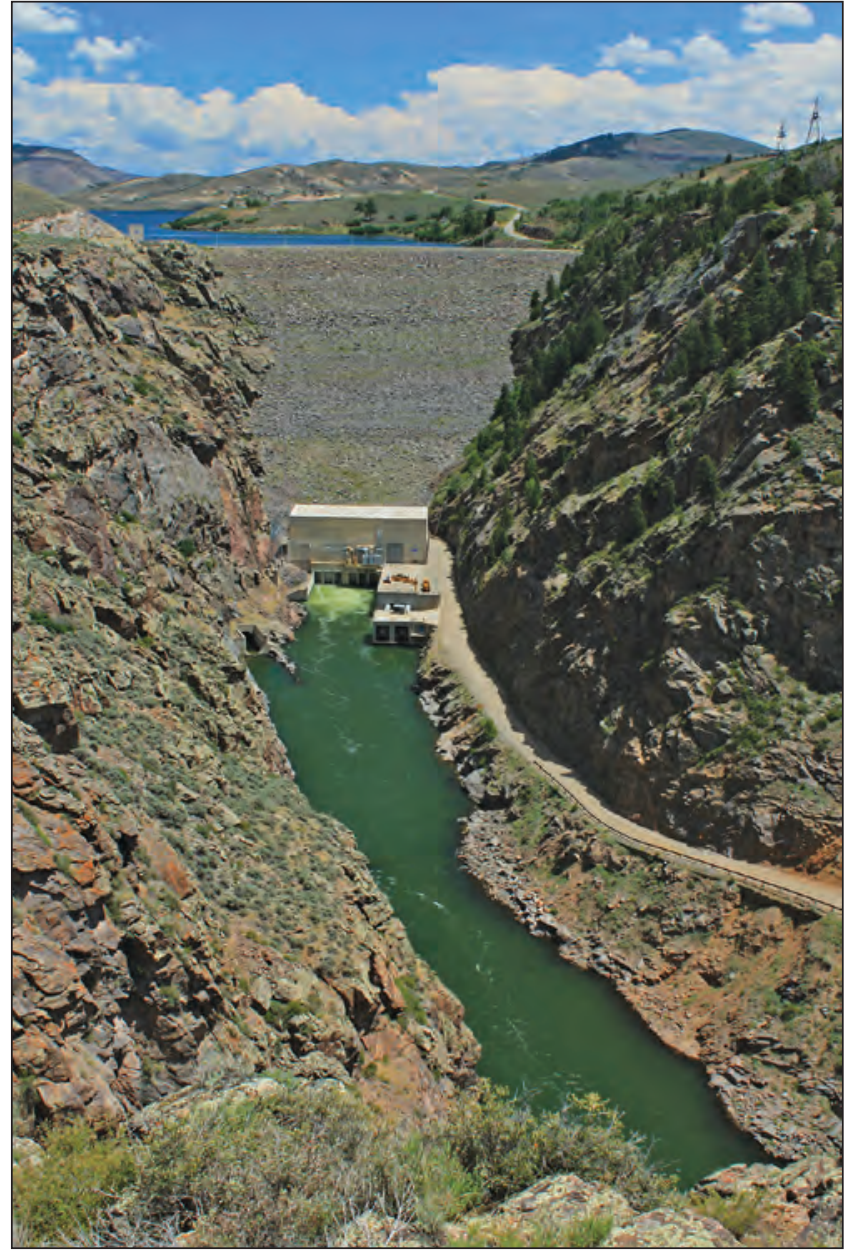

Blue Mesa Dam, Gunnison River, Curecanti National Recreation Area, Gunnison County, Colo. 


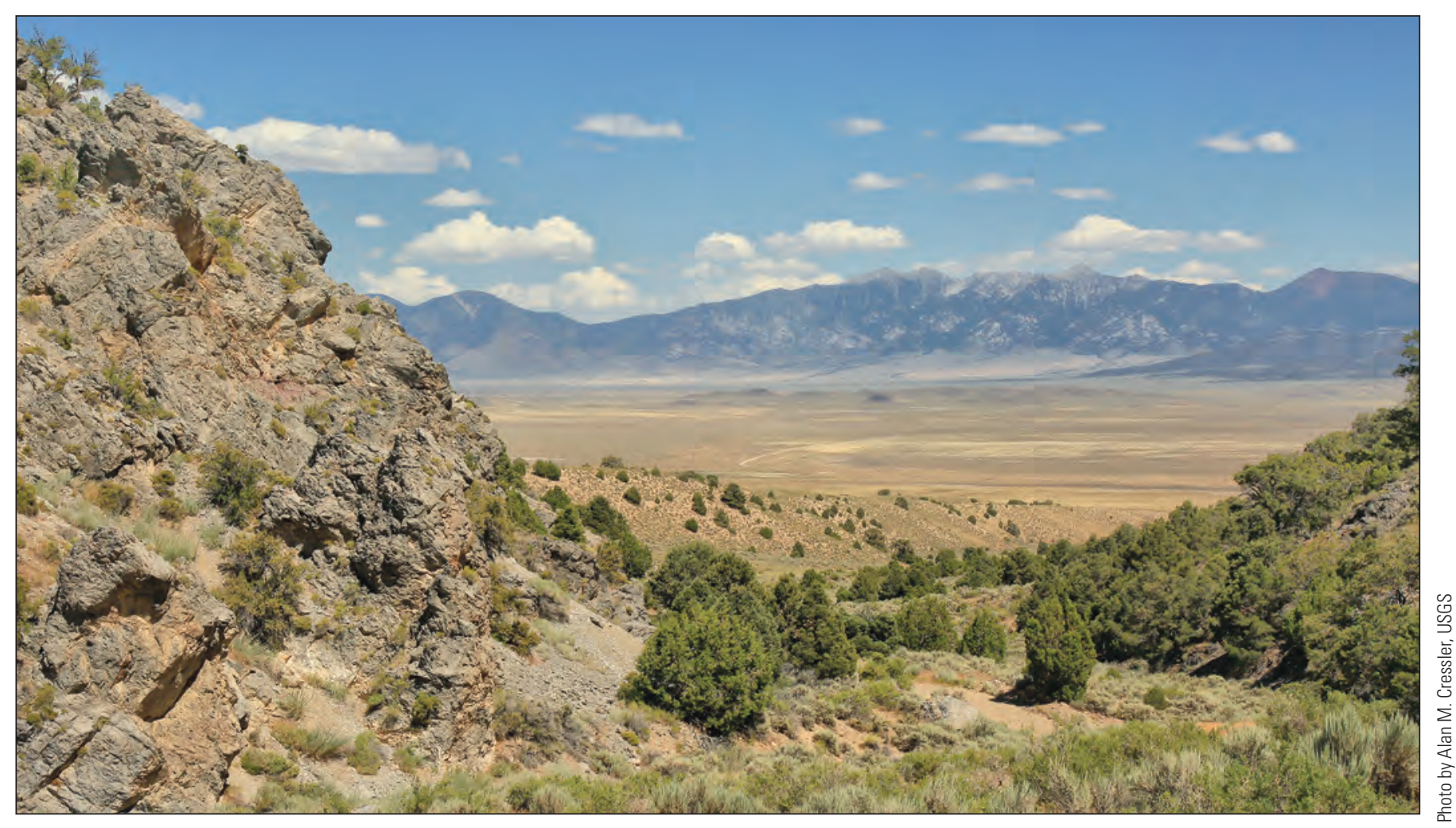

View of Antelope Vallley, Nev.

\section{Landscape Effects}

\section{Habitat Connectivity Study Describes a Framework for Conserving At-Risk Species}

Conservation planning and biodiversity management require information on landscape connectivity across a range of spatial scales from individual animal home ranges to large regions. The USGS is leading a study that will provide a multiscale connectivity framework to aid habitat conservation prioritization in the context of changing land use and climate.

\section{Contact}

Todd Esque, USGS Western Ecological Research Center; tesque@usgs.gov; (702) 564-4506

\section{Publication}

Dilts, T.E., Weisberg, P.J., Leitner, Philip, Matocq, M.D., Inman, R.D., Nussear, K.E., and Esque, T.C., 2016, Multiscale connectivity and graph theory highlight critical areas for conservation under climate change: Ecological Applications, v. 26, no. 4, p. 1223-1237, http://dx.doi.org/10.1890/15-0925.

\section{Habitat Suitability and Climate Change Modeling to Inform Renewable Energy Development}

The USGS is collaborating with the California Energy Commission, Desert Landscape Conservation Cooperative partners, the University of Nevada at Reno, and others to develop conceptual models and habitat suitability models for more than 50 desert plant and animal species. The models are used to predict current habitat needs, and when joined with climate change scenarios the models can be used to evaluate impacts associated with renewable energy development in relation to impacts expected from climate change. With these models, species can now be ranked in relation to potential habitat loss as a result of proposed renewable energy development. The latest study used species distribution models and partial dispersal models to assess the projected impact of climate change and energy development and to predict future distributions of the Mojave ground squirrel (Xerospermophilus mohavensis). Maps were produced to assist resource managers in evaluating conservation corridors, developing sampling designs, and informing development planning.

\section{Contacts}

Todd Esque, USGS Western Ecological Research Center; tesque@usgs.gov; (702) 564-4506

Amy Vandergast, USGS Western Ecological Research Center; avandergast@usgs.gov; (619) 225-6445 


\section{Publications}

Inman, R.D., Esque, T.C., Nussear, K.E., Leitner, Philip, Matocq, M.D., Weisberg, P.J., and Dilts, T.E., 2016, Impacts of climate change and renewable energy development on habitat of an endemic squirrel, Xerospermophilus mohavensis, in the Mojave Desert, U.S.A.: Biological Conservation, v. 200, p. 112-121, http://dx.doi.org/10.1016/j.biocon.2016.05.033.

Inman, R.D., Esque, T.C., Nussear, K.E., Leitner, P., Matocq, M.D., Weisberg, P.J., Dilts, T.E., and Vandergast, A.D., 2013, Is there room for all of us? Renewable energy and Xerospermophilus mohavensis: Endangered Species Research, v. 20, no. 1, p. 1-18, http://dx.doi.org/ $10.3354 /$ esr00487.

Inman, R.D., Nussear, K.E., Esque, T.C., Vandergast, A.G., Hathaway, S.A., Wood, D.A., Barr, K.R., and Fisher, R.N., 2014, Mapping habitat for multiple species in the Desert Southwest: U.S. Geological Survey Open-File Report 2014-1134, 92 p., http://dx.doi.org/10.3133/ ofr20141134.

\section{Landscape-Scale Measures of Genetic Diversity Assist in Siting Renewable Energy Facilities}

An "evolutionary hotspot" is a region that shows spatial overlap in high genetic diversity and divergence for many species. The USGS has identified 10 such hotspots in the Mojave Desert and has assessed overlap with proposed renewable energy developments. Researchers mapped the population genetic structure for 17 animal species across the Mojave Desert, including four species listed as threatened, endangered, or of special concern. Results showed a 17 percent overlap of hotspots with planned renewable energy project footprints and transmission line corridors. Resulting maps can be incorporated into management and planning efforts and used to identify specific regions where further studies may be needed to discern the effects of development on animal populations and connectivity.

Contacts

Amy Vandergast, USGS Western Ecological Research Center; avandergast@usgs.gov; (619) 225-6445

Todd Esque, USGS Western Ecological Research Center; tesque@usgs.gov; (702) 564-4506

Publications

Vangergast, Amy, Inman, Richard, Barr, Kelly, Nussear, Kenneth, Esque, Todd, Hathaway, Stacie, Wood, Dustin, Medica, Philip, Breinholt, Jesse, Stephen, Catherine, Gottscho, Andrew, Marks, Sharyn, Jennings, W., and Fisher, Robert, 2013, Evolutionary hotspots in the Mojave Desert: Diversity v. 5, no. 2, p. 293-319, http://dx.doi.org/10.3390/d5020293.

Wood, D.A., Vandergast, A.G., Barr, K.R., Inman, R.D., Esque, T.C., Nussear, K.E., Fisher, R.N., and Bode, Michael, eds., 2012, Comparative phylogeography reveals deep lineages and regional evolutionary hotspots in the Mojave and Sonoran Deserts: Diversity and Distributions, v. 19, no. 7, p. 722-737, http://dx.doi.org/10.1111/ddi.12022.

\section{Integrated Assessment for Southwest Wyoming}

The USGS is providing an integrated assessment of the effects of energy development on the Wyoming Landscape Conservation Initiative focal ecosystems to inform planning and decisionmaking in southwest Wyoming. Scientists will evaluate the natural, economic, and social context for energy development and other land uses, and focus on informing conservation actions and decisions. Specifically, the assessment will identify areas with high conservation and restoration potential, and high development potential on the current landscape. This assessment includes conventional and renewable energy resources, with special attention to wind energy.

Contact

Zachary Bowen, USGS Fort Collins Science Center; bowenz@usgs.gov; (970) 226-9218

\section{Wyoming Wind Energy Disturbance Mapping}

The USGS is quantifying land-surface disturbance associated with the development and operation of wind facilities for the BLM Wyoming Renewable Energy Coordination Office. Scientists are quantifying all infrastructure associated with wind energy development, surface disturbance, and re-vegetation or reclamation following initial wind-facility development. Results will document the amount and pattern of disturbance over time during the development and operation of facilities in Wyoming. This information may be useful for planning and assessment of future wind projects.

Contact

Zachary Bowen, USGS Fort Collins Science Center; bowenz@usgs.gov; (970) 226-9218 


\section{Wind and Wildlife Interactions in Airspace}

Knowledge of how airspace use varies by species, altitude, and season is fundamental for assessing the risks of wind energy development to wildlife. Efforts to associate wind energy mortality with traditional ground-based technologies have been largely unsuccessful, likely due in part to the traditional two-dimensional view of animal flight patterns. Understanding flight patterns and intensities at heights where turbine interactions may occur, generally 30 to 200 meters above ground level, around existing and planned wind energy facilities could greatly facilitate risk assessment and planning. USGS researchers are evaluating the application of new tools and novel strategies to determine the flight intensity of birds, bats, and other flying animals within airspace, with a focus on the vertical dimension. As a test case, information from this study will aid the development of a comprehensive strategy for assessing wind energy impacts on wildlife for the Upper Midwest.

Contact

Douglas H. Johnson, USGS Northern Prairie Wildlife Research Center; douglas_h_johnson@usgs.gov; (612) 624-4716

\section{Geographic Context in Wind Energy Land Transformation}

Land transformation, measured as hectares of surface disturbance per megawatt, associated with wind facilities shows wide variation in its reported values. USGS scientists digitized land transformation at 39 wind facilities by using high-resolution aerial imagery and investigated how turbine size, configuration, land cover, and topography affected the levels of total land transformation. The results indicate the geographic context in which facilities are installed affects the levels of land transformation associated with wind energy. For example, flat topographies had the lowest land transformation, while facilities on mesas had the largest. This information can assist managers with decisions on how to create opportunities for wind energy production that minimize land-cover change through effective siting. Scientists are now investigating the role of geographic context on road networks and how this affects habitat fragmentation around new facilities.

\section{Contact}

Jay Diffendorfer, USGS Geosciences and Environmental Change Science Center; jediffendorfer@usgs.gov; (303) 236-5369

Publications

Diffendorfer, J.E., Beston, D.A., Merrill, M.D., Stanton, J.C., Corum, M.D., Loss, S.R., Thogmartin, W.E., Johnson, D.H., Erickson, R.A., and Heist, K.W., 2015, Preliminary methodology to assess the national and regional impact of U.S. wind energy development on birds and bats: U.S. Geological Survey Scientific Investigations Report 2015-5066, 40 p., http://dx.doi.org/10.3133/sir20155066.

Diffendorfer, J.E., and Compton, R.W., 2014, Land cover and topography affect the land transformation caused by wind facilities: PLOS ONE, v. 9, no. 2, e88914, http://dx.doi.org/10.1371/journal.pone.0088914.

\section{Terrestrial Impacts of Mountaintop Mining}

Ecological research on mountaintop mining has been focused on aquatic impacts because the overburden, or mountaintop, is disposed of in nearby valleys, which leads to a wide range of water-quality impacts on streams. Numerous impacts on the terrestrial environment from mountaintop mining also have been largely overlooked, even though they are no less wide ranging, severe, and multifaceted. USGS scientists are reviewing the impacts of mountaintop mining on the terrestrial environment by exploring six broad themes: the loss of topographic complexity, forest loss and fragmentation, forest succession and soil loss, forest loss and carbon sequestration, biodiversity, and human health and well-being. This study assists managers and regulators in evaluating the full impacts of mountaintop mining by complementing existing research focused on assessing impacts to aquatic environments.

\section{Contact}

Petra Wood, USGS West Virginia Cooperative Fish and Wildlife Research Unit; pbwood@wvu.edu; (304) 293-5090

\section{Publication}

Wickham, J., Wood, P.B., Nicholson, M.C., Jenkins, W., Druckenbrod, D., Suter, G.W., Strager, M.P., Mazzarella, C., Galloway, W., and Amos, J., 2013, The overlooked terrestrial impacts of mountaintop mining: BioScience v. 63, no. 5, p. 335-348, http://dx.doi.org/ 10.1525/bio.2013.63.5.7. 


\section{Ecological Effects of Brine Contamination From Energy Production in the Prairie Pothole Region}

Energy production in the Williston Basin results in the co-production of highly saline, sodium chloride dominated, water, or brine. USGS researchers examined the effects of contamination from production waters derived from oil and gas development on macroinvertebrate communities and above-ground biomass and plant tissue chemistry of hardstem bulrush (Schoenoplectus acutus). Scientists sampled 10 wetlands across a contamination gradient in the Prairie Pothole Region (PPR) and collected samples to determine macroinvertebrate taxonomic richness, biomass, and plant tissue chloride concentrations. Results will provide information on potential effects of production brine on primary productivity and benthic biota in PPR wetlands.

Contact

Todd Preston, USGS Northern Rocky Mountain Science Center; tmpreston@usgs.gov; (406) 994-5034
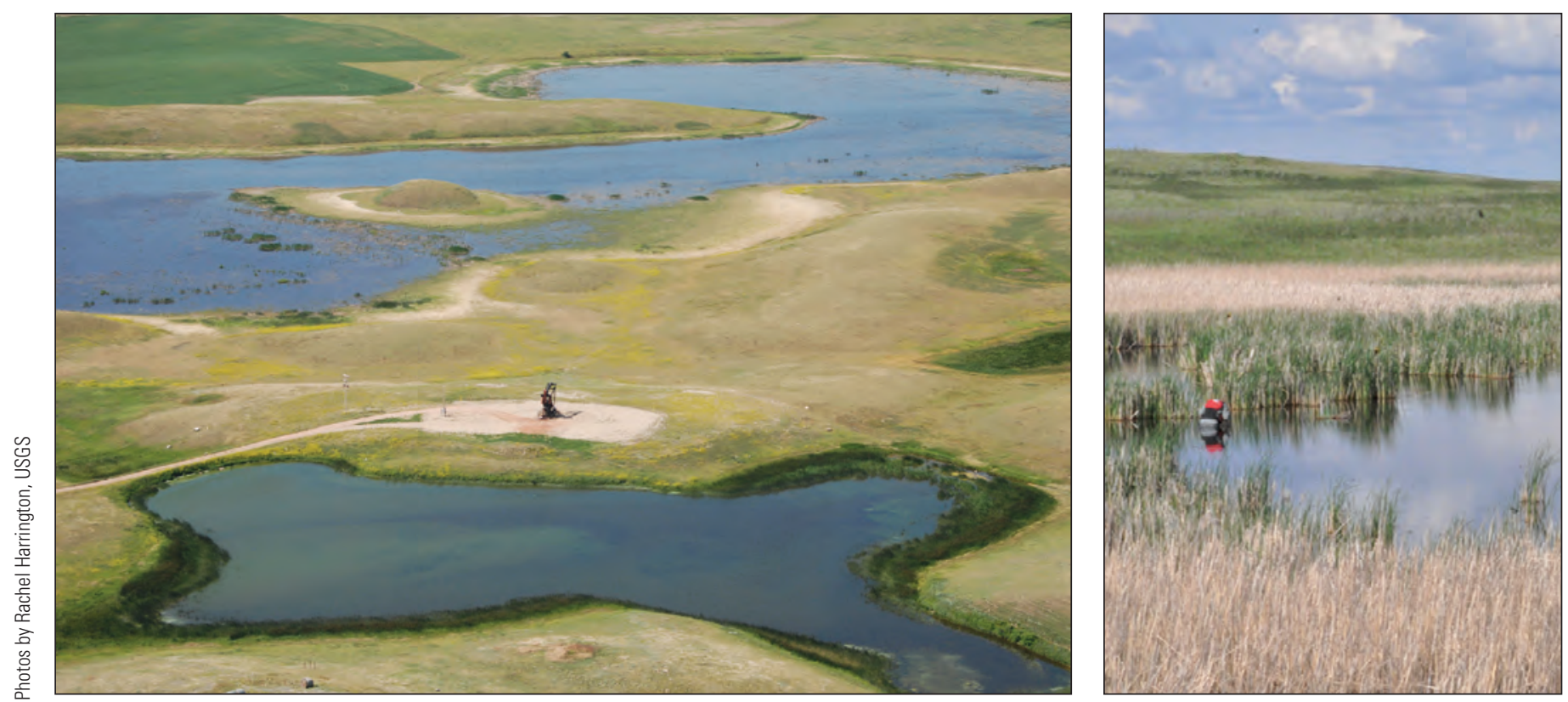

Insect traps in a wetland in North Dakota's Prairie Pothole Region.

\section{Land-Cover Changes Associated With Recent Energy Development in the Williston Basin}

The Williston Basin in the Northern Great Plains has experienced rapid energy development since 2000. USGS researchers evaluated land-cover changes from recent (2000-2015) development and found that it had converted 12,990 hectares of predominantly agricultural or prairie land and disturbed 12,121 additional hectares. Future land-cover changes are forecasted to be 2.7 times greater than the evaluated period based on the number of wells expected by 2050 as reported by the North Dakota Industrial Commission in 2014 (https:/www.dmr.nd.gov/oilgas/presentations/NDOGCPC091814.pdf). Although future development will result in substantial land-cover change, evolving industry practices and proactive siting decisions, such as development along energy corridors and placing pads in areas previously altered by human activity, have the potential to reduce the ecological effects of future energy development in the Williston Basin.

Contact

Todd Preston, USGS Northern Rocky Mountain Science Center; tmpreston@usgs.gov; (406) 994-5034

\section{Publication}

Preston T.M., and Kim, Kevin, 2016, Land cover changes associated with recent energy development in the Williston Basin; Northern Great Plains, U.S.A.: Science of the Total Environment, v. 566-567, p. 1511-1518, http://dx.doi.org/10.1016/j.scitotenv.2016.06.038. 


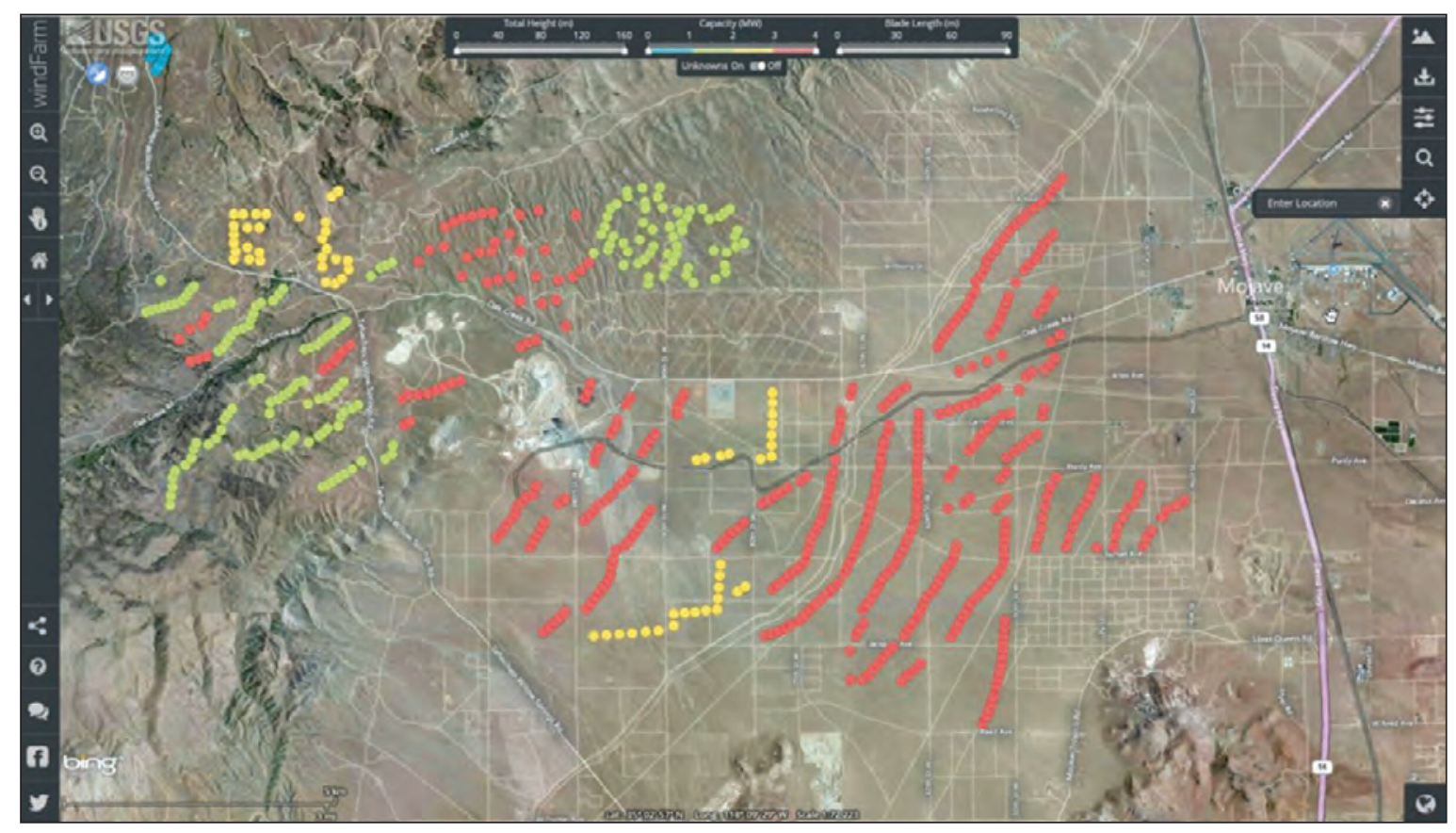

A screenshot from the USGS WindFarm Mapping Application showing locations and types of turbines in southern California. (http://eerscmap.usgs.gov/windfarm/).

\section{Management Support Tools}

\section{Understand Risks}

\section{Onshore Industrial Wind Turbine Locations}

The USGS updated a national dataset of onshore, industry-scale wind turbines in the United States through March 2014. Turbine locations were obtained from the Federal Aviation Administration (FAA) Digital Obstacle File; data were digitized and spatially verified. Turbines without FAA Obstacle Repository System numbers were obtained from publicly available facility datasets and were visually identified; point locations were added to the collection. Turbine position was verified using high-resolution aerial imagery with a final locational error of less than 10 meters. Technical specifications such as height, blade length, rotor swept area, model, and size were attributed for the majority of turbines on the basis of a variety of sources. This map of onshore commercial scale wind turbines can assist scientists, regulatory agencies, nongovernmental organizations, and other decisionmakers in more easily assessing and planning for the effects of wind energy development on federally protected species.

\section{Contact}

Jay Diffendorfer, USGS Geosciences and Environmental Change Science Center; jediffendorfer@usgs.gov; (303) 236-5369

\section{Publication}

Diffendorfer, J.E., Compton, Roger, Kramer, Louisa, Ancona, Zach, and Norton, Donna, 2014, Onshore industrial wind turbine locations for the United States through July 2013 (ver. 1.1, May 2015): U.S. Geological Survey Data Series 817, http://dx.doi.org/10.3133/ds817.

\section{Pre-Construction Assessment: Bird and Bat Risk From Wind Development—A Review}

The USGS and university scientists summarized current pre-construction assessment risks to wildlife from wind turbines. Researchers described the number of species and individuals affected by blade-strikes and discuss how and why pre-construction monitoring is conducted. Several shortcomings in methods used to assess the risk of fatality at turbines were noted, including the lack of studies to offer evidence for a relationship between pre-construction surveys and post-construction fatality.

\section{Contact}

Todd Katzner, USGS Forest and Rangeland Ecosystem Science Center; tkatzner@usgs.gov; (208) 426-5232

\section{Publication}

Katzner, Todd, Bennett, Victoria, Miller, Tricia, Duerr, Adam, Braham, Melissa, and Hale, Amanda, 2016, Wind energy developmentMethods for assessing risks to birds and bats pre-construction: Human-Wildlife Interactions, v. 10, no. 1, p. 42-52, https://pubs.er.usgs.gov/ publication/70170981. 


\section{Sensitive and Rare Plant Distributions and Energy Development in the Colorado Plateau}

USGS scientists are leading a 4-year effort organizing existing data on 21 federally listed, rare and sensitive plant species in the Colorado Plateau. Scientists also are collecting new data on plant locations and developing distribution models indicating the likelihood of plants being present in specified locations. The plant species distribution models are being analyzed in relation to existing and proposed renewable and nonrenewable energy development in the Colorado Plateau. Optimization models are being developed to identify lands where management and conservation conflicts between sensitive and rare plant species could be minimized. Results from this study will help decisionmakers select variable risk strategies depending on desired management and energy development goals.

Contact

Thomas Edwards, USGS Utah Cooperative Fish and Wildlife Research Unit; t.edwards@nr.usu.edu; (435) 797-2529

\section{Measure Impacts}

\section{Tools to Help Assess Energy Development Impacts to Sensitive Birds and Bats}

A new USGS project will use a combination of tools to understand how mortality at renewable energy facilities affects populations of sensitive bird and bat species in California. As part of this project, stable isotopes will be used to estimate the geographic scope of the population of birds or bats affected, and demographic modeling will forecast how individual fatalities affect the growth or decline of species' populations. Development of analytical methods will aid in determining the best practices for conducting risk assessments and predicting mitigation outcomes. These tools will allow energy developers to more accurately estimate fatality rates and effects of mitigation techniques at wind and solar energy facilities, which will streamline permitting and ultimately reduce costs of energy development.

Contact

Todd Katzner, USGS Forest and Rangeland Ecosystem Science Center; tkatzner@usgs.gov; (208) 426-5232

\section{Post-Construction Assessment of Risk to Birds and Bats From Wind Energy—A Review}

Unbiased estimates of bird and bat fatalities caused by wind power infrastructure are critical to understanding effects on species populations and devising effective methods to mitigate or minimize deaths. Accurate estimation is complicated because animals killed at facilities may go undetected when carcasses fall outside the search area, are removed by scavengers, or missed by searchers during surveys. USGS and USFWS researchers reviewed currently used methods to estimate bird and bat fatality rates at wind power facilities and discussed the role of these estimators in determining minimization and mitigation impacts to species of concern. Estimators of wind turbinecaused fatalities that account for sources of imperfect detection yield a more accurate fatality estimate. Using appropriate monitoring protocols and an unbiased estimator on a statistically selected sample of sites are actions management agencies can take to evaluate the cumulative effect of wind power development on

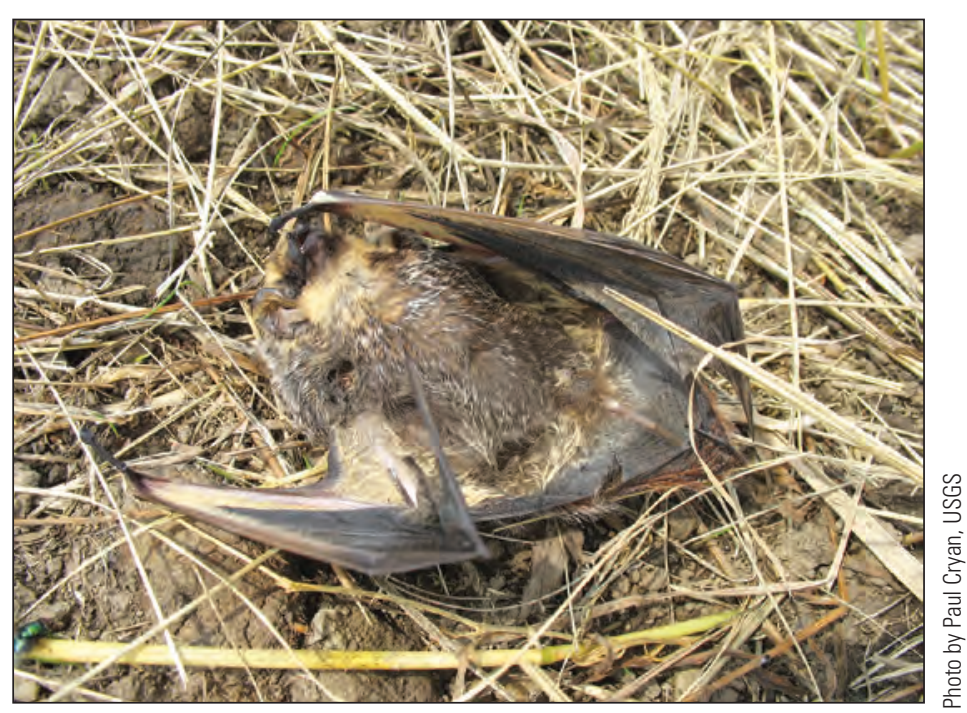

Bat fatality found under a wind turbine. wildlife at national or regional scales.

\section{Contact}

Manuela Huso, USGS Forest and Rangeland Ecosystem Science Center; mhuso@usgs.gov; (541) 750-0948

\section{Publication}

Huso, Manuela, Dalthorp, Dan, Miller, T.J, and Bruns, Dawn, 2016, Wind energy development-Methods to assess bird and bat fatality rates post-construction: Human-Wildlife Interactions v. 10, no. 1, p. 62-70, http://berrymaninstitute.org/files/uploads/pdf/journal/spring2016/ WindEnergyDevelopmentMethodsHusoEtal.pdf. 


\section{Estimates of Avian Fatalities at Wind Energy Facilities in the United States-A Review}

The USGS lead a team of scientists to compare and contrast three recently published annual avian fatality estimates by wind energy facilities in the United States. The three estimates differed in scope, methodology, and resulting estimates. A critical question asked was how representative is the available information on fatalities at wind energy facilities? Despite the variation in the three approaches, resulting estimates were reasonably similar, showing a quarter- to a half-million birds were directly killed per year by colliding with wind turbines.

\section{Contact}

Douglas H. Johnson, USGS Northern Prairie Wildlife Research Center; douglas_h_johnson@usgs.gov; (612) 624-4716

\section{Publication}

Johnson, D.H., Loss, S.R., Smallwood, K.S., and Erickson, W.P., 2016, Avian fatalities at wind energy facilities in North America-A comparison of recent approaches: Human-Wildlife Interactions, v. 10, no. 1, p. 7-18, http://www.berrymaninstitute.org/files/uploads/ pdf/journal/spring2016/AvianFatalitiesJohnsonEtal.pdf.

\section{Accounting for Fatalities Falling in Unsearched Areas}

Fatality monitoring protocols, particularly the size and configuration of a searched area, differ widely among studies, resulting in a very different proportion of the total carcass population represented in each study. USGS statisticians evaluated models relating carcass density to distance from wind turbines to estimate the proportion of carcasses expected to fall within searched areas of varying configuration. Accurately modeling change in carcass density with distance to account for differing search area configurations will result in less bias in fatality estimates.

Contact

Manuela Huso, USGS Forest and Rangeland Ecosystem Science Center; mhuso@usgs.gov; (541) 750-0948

Publication

Huso, M.M.P., and Dalthorp, Dan, 2014, Accounting for unsearched areas in estimating wind turbine-caused fatality: Journal of Wildlife Management, v. 78, no. 2, p. 347-358, http://dx.doi.org/10.1002/jwmg.663.

\section{Estimating Wildlife Mortality From Collisions With Structures}

Accurate counts of wildlife mortalities from collisions with manmade structures can be difficult because carcasses may not be detected or may be scavenged. USGS and an international team of researchers devised software to estimate wildlife mortality from the number of carcasses found and the probability that an animal may be found that has died from a collision.

Contact

Manuela Huso, USGS Forest and Rangeland Ecosystem Science Center; mhuso@usgs.gov; (541) 750-0948

Publication

Korner-Nievergelt, Fränzi, Behr, Oliver, Brinkmann, Robert, Etterson, M.A., Huso, M.M.P., Dalthorp, Dan, Korner-Nievergelt, Pius, Roth, Tobias, and Niermann, Ivo, 2015, Mortality estimation from carcass searches using the R-package carcass-A tutorial: Wildlife Biology, v. 21, no. 1, p. 30-43, http://dx.doi.org/10.2981/wlb.00094.

\section{Evidence of Absence or Absence of Evidence?}

The statistical tools used to estimate fatalities from bird and bat carcasses observed below turbines are fairly robust when observed counts are relatively high, but often no carcasses are observed for rare and endangered species. In addition, no carcasses would be observed if no deaths occurred or if perhaps several occurred but were missed during the search process. Distinguishing these two cases is critical for protected species where the loss of even one or two individuals may have a negative impact on the population. The USGS has developed a method to estimate the number of carcasses that could have been missed, even when none were found. To make this work accessible to managers, the method has been packaged into a decision support tool that will help resource managers design monitoring protocols that optimize detection probability at the lowest cost, evaluate whether permitted "take" rate is likely to have been exceeded, and project future take to inform adaptive management.

Contact

Manuela Huso, USGS Forest and Rangeland Ecosystem Science Center; mhuso@usgs.gov; (541) 750-0948

Publications

Dalthorp, Dan, Huso, Manuela, Dail, David, and Kenyon, Jessica, 2014, Evidence of absence software user guide: U.S. Geological Survey Data Series 881, 34 p., http://dx.doi.org/10.3133/ds881. 
Dalthorp, Daniel, and Huso, Manuela, 2015, A framework for decision points to trigger adaptive management actions in long-term incidental take permits: U.S. Geological Survey Open-File Report 2015-1227, http://dx.doi.org/10.3133/ofr20151227.

Huso, M.M.P., Dalthorp, Dan, Dail, David, and Madsen, Lisa, 2015, Estimating wind-turbine caused bird and bat fatality when zero carcasses are observed: Ecological Applications, v. 25, no. 5, p. 1213-1225, http://dx.doi.org/10.1890/14-0764.1.

\section{Estimation of Bird and Bat Mortality at Wind-Power Farms With Super-Population Models}

Collision of birds and bats with turbines in utility-scale wind energy facilities is an increasing cause of concern, and carcass counts conducted to quantify the "take" of protected species need to be corrected for carcass persistence probability and detection probability. The USGS developed super-population capture-recapture models to perform the required corrections to the raw count data. The approach to estimate wind farm mortality based on data from carcass surveys is flexible and can accommodate a range of different sampling designs and biological hypotheses. Mortality estimates can be used to quantify the required amount of compensation actions, inform mortality projections for proposed wind development sites, and inform decisions about management of existing wind energy facilities.

Contacts

James Hines, USGS Patuxent Wildlife Research Center; jhines@usgs.gov; (301) 497-5661

William Kendall, USGS Colorado Cooperative Fish and Wildlife Research Unit; wkendall@usgs.gov; (970) 491-7066

Publication

Péron, Guillaume, Hines, J.E., Nichols, J.D., Kendall, W.L., Peters, K.A., Mizrahi, D.S., and Matthiopoulos, Jason, eds., 2013, Estimation of bird and bat mortality at wind-power farms with superpopulation models: Journal of Applied Ecology v. 50, no. 4, p. 902-911, http://dx.doi.org/10.1111/1365-2664.12100.

\section{Assessing Avoidance of Wind Turbines by Birds}

Optimal conditions for experimental studies, notably random assignment of treatments to study units, are impossible to achieve in studies of avoidance of wind turbines by birds. For some such situations, Before-After, Control-Impact (BACI) designs have been proposed. BACI designs require information about sites before and after installation as well as parallel information about similar sites where turbines are not installed. Another approach is the gradient method, essentially a dose-response analysis, in which metrics such as bird occurrence rates at a site are evaluated in relation to distance from the nearest wind turbine. USGS researchers are evaluating the strengths and weaknesses of these various methods and additional issues that can complicate analysis. This work will provide improved tools for decisionmakers in evaluating the impacts of wind energy development on wildlife.

Contact

Douglas H. Johnson, USGS Northern Prairie Wildlife Research Center; douglas_h_johnson@usgs.gov; (612) 624-4716

\section{Detecting Population-Level Impacts of Wind Energy Development}

The impact of wind energy generation on wildlife is commonly approached by monitoring the incidence of mortality resulting from turbine collisions. These mortality events may or may not scale up to observable impacts at a population level. USGS scientists are developing a framework for assessing population-level impacts of wind energy using abundance time-series data and turbine location maps. The two-part approach first examines whether the timing and placement of turbines on the landscape is coincident with observed population trends at regional scales using dynamic factor analysis. Next, localized impacts are examined by comparing population trends from sampling locations in close proximity to wind turbine development with relatively distant locations using Bayesian structural time-series models. This research will assist conservation managers with wind energy project permitting and use and interpretation of monitoring protocols for wind facilities.

Contact

Wayne Thogmartin, USGS Upper Midwest Environmental Sciences Center; wthogmartin@usgs.gov; (608) 781-6309

\section{Publication}

Erickson, R. A., Eager, E. A., Stanton, J.C., Beston, J.A, Diffendorfer, J.E., and Thogmartin, W.E., 2015, Assessing local population vulnerability with branching process models - An application to wind energy development: Ecosphere v. 6, no. 12, art254, http://dx.doi.org/10.1890/es15-00103.1. [For more details, see https://sites.google.com/a/uwlax.edu/eric-eager/service/universityof-wisconsin---la-crosse-math-bio-working-group.] 


\section{Wind Energy Impacts Assessment Methodology Project}

USGS scientists are evaluating national to regional impacts of wind energy on bats and birds that breed in and migrate through the United States by developing a wind energy impacts assessment methodology. The methodology focuses primarily on the effects of collisions between wildlife and turbines. Primary uses of this methodology, which is complementary to and incorporates detailed studies and demographic models on key species, include (1) quantitative measuring of the potential impacts to species' populations through demographic modeling and the use of potential biologic removal methods; (2) ranking species in terms of their direct and indirect relative risk to wind energy development; (3) recommending species for more intensive demographic modeling or study; and (4) highlighting species for which the effects of wind energy development on their populations are projected to be small. The researchers will also investigate causes of variation in fatality rates across facilities and levels of sampling effort and identification of species killed at wind turbines. This methodology can be used to evaluate species for more or less intensive demographic modeling based on the projected impacts from wind energy development on the populations of the species.

\section{Contact}

Jay Diffendorfer, USGS Geosciences and Environmental Change Science Center; jediffendorfer@usgs.gov; (303) 236-5369

\section{Publication}

Diffendorfer, J.E., Beston, J.A., Merrill, M.D., Stanton, J.C., Corum, M.D., Loss, S.R., Thogmartin, W.E., Johnson, D.H., Erickson, R.A., and Heist, K.W., 2015, Preliminary methodology to assess the national and regional impact of U.S. wind energy development on birds and bats: U.S. Geological Survey Scientific Investigations Report 2015-5066, 40 p., http://dx.doi.org/10.3133/sir20155066.

\section{Inform Solutions}

\section{Energy Futures for Wyoming}

As part of the Wyoming Landscape Conservation Initiative (WLCI), the USGS is mapping the locations and extents of potential electricity-generating resources in Wyoming. This work includes mapping resources, such as natural gas, coal, wind, and hydropower, as well as transmission and transportation corridors. Results of this work will be used to inform the WLCI and other energy-related studies. More broadly, USGS researchers are developing an energy-assessment framework and methods that can be used in other regions.

\section{Contact}

Zachary Bowen, USGS Fort Collins Science Center; bowenz@usgs.gov; (970) 226-9218

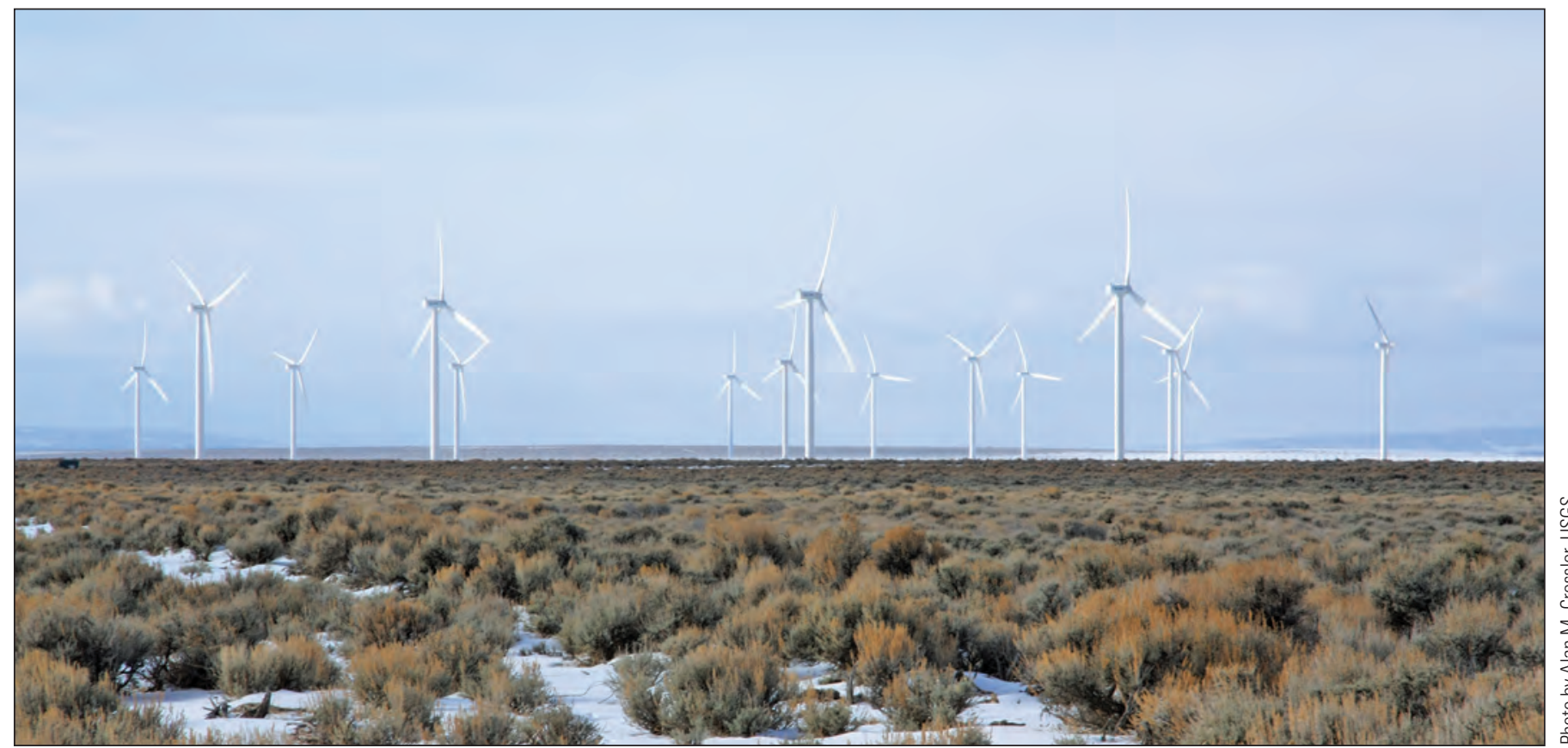

Wind farm in Unita County, Wyo. 


\section{Informing Energy Development Siting Decisions With Vertebrate Biodiversity Measures}

USGS researchers are gathering information about vertebrate biodiversity needed by management agencies in Arizona to inform siting guidance for energy development on public lands. Siting guidance may help managers in identifying potential energy development conflicts with species of conservation concern. Scientists will use watershed-scale range models for vertebrate species developed through the USGS National Gap Analysis Program to illustrate how indices of biodiversity can be incorporated into renewable energy siting decisions.

Contact

Kathryn Thomas, USGS Southwest Biological Science Center; kathryn_a_thomas@usgs.gov; (520) 670-6671 x 238

\section{References Cited}

Hein, C.D., and Schirmacher, M.R., 2016, Impact of wind energy on bats: a summary of our current knowledge: HumanWildlife Interactions, v. 10, no. 1, p. 19-27, accessed September 1, 2016, at http:/www.berrymaninstitute.org/files/ uploads/pdf/journal/spring2016/ImpactWindEnergyHeinSchirmacher.pdf.

Johnson, D.H., Loss, S.R., Smallwood, K.S., and Erickson, W.P., 2016, Avian fatalities at wind energy facilities in North AmericaA comparison of recent approaches: Human-Wildlife Interactions, v. 10, no. 1, p. 7-18, accessed September 1, 2016, at http://www.berrymaninstitute.org/files/uploads/pdf/journal/spring2016/AvianFatalitiesJohnsonEtal.pdf.

North Dakota Industrial Commission, 2014, North Dakota producing counties update, accessed September 1, 2016, at https://www.dmr.nd.gov/oilgas/presentations/NDOGCPC091814.pdf.

U.S. Energy Information Administration, 2016, Preliminary Monthly Electric Generator Inventory, accessed September 1, 2016, at https://www.eia.gov/todayinenergy/detail.cfm?id=25492.

U.S. Fish and Wildlife Service, 2013, Eagle Conservation Plan Guidance, accessed September 2, 2016, at https://www.fws.gov/ migratorybirds/pdf/management/eagleconservationplanguidance.pdf.

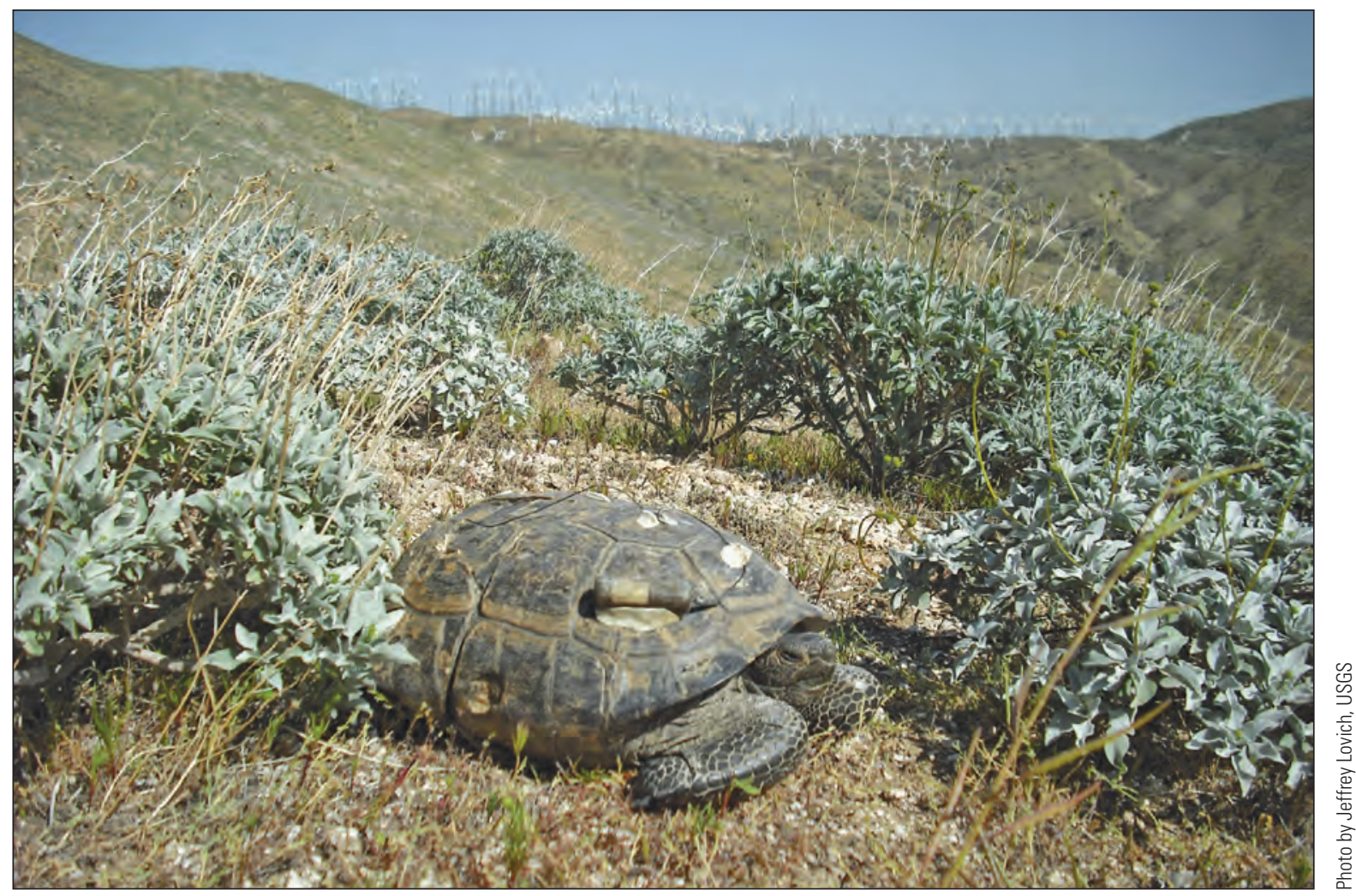

Desert tortoise with a radio near Palm Springs, Calif. 

Manuscript approved August 31, 2016

Prepared by the USGS Science Publishing Network Reston Publishing Service Center

Edited by Kay P. Naugle

Layout by Caryl J. Wipperfurth

For additional information regarding this publication, please contact:

Mona Khalil

mkhalil@usgs.gov

Or visit the USGS Energy and Wildlife Program

https://www2.usgs.gov/ecosystems/energy_wildlife 
